\title{
Searching for the Soul of Europe
}

The Impact of the Sovereign Debt Crisis on an 'Ever Closer Union'

Finnian O'Dwyer-Cunliffe

A thesis submitted to the Victoria University of Wellington in fulfilment of the requirements for the degree of Master of Arts in Political Science

TE WHARE WĀNANGA O TE ŪPOKO O TE IKA A MĀUI

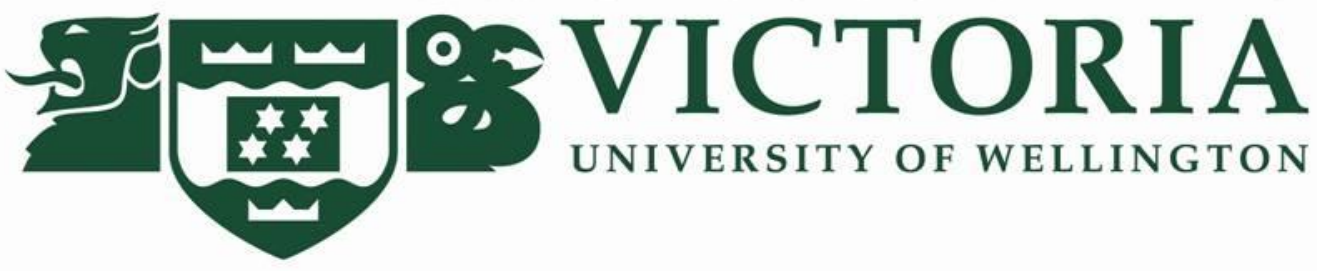

July 2014 


\begin{abstract}
The destruction of global financial markets and the collapse of the Greek and Irish economies in 2010 caused a ripple effect that spread across the Eurozone and presented the EU with an unprecedented crisis. The level of economic devastation led many to question the integrity of the single currency and the direction of the European project as a whole. This thesis has examined three rounds of debate during the Sovereign Debt Crisis between 2010 and 2014, in order to ascertain the effect of this period on three competing 'visions' for the future of Europe. It has found that efforts to reform economic governance in the EU in the wake of the crisis have for the most part led to an entrenchment of the consolidation orthodoxy sponsored by Germany and its allies in northern Europe. However, a political turning point in mid-2012 led to a reprieve for the European Left and the subsequent advancement of the Social European vision advocating greater solidarity in the place of fiscal austerity. While the consolidation coalition's commitment to economic stability and oversight has for the most part been maintained, the shifting balance of power in European politics, and an increasing frustration with the failures of austerity, have provided momentum for a major revision to the status quo. This thesis has found that while the Eurosceptic rise in the 2014 elections has raised serious questions for the EU, it has highlighted the unwavering commitment towards further integration among the dominant political actors in Europe, and will most likely set the Continent further along the path towards an ever closer union.
\end{abstract}




\section{Contents}

$\begin{array}{ll}\text { Introduction } & 1\end{array}$

1. The Sovereign Debt Crisis and Three Visions for Europe 6

$\begin{array}{ll}\text { 1.1 Road to the crisis: How the great experiment failed } & 7\end{array}$

1.2 An ever closer union? The three visions 18

2. The Fiscal Compact: Shaping the 'Austerity Union' 34

2.1 To treaty or not to treaty: All for one and one for all? 35

2.2 A line in the sand: European Schuldenbremse 41

2.3 Blocking the pact: Sovereign democracy and the European Left 45

2.4 A ratified Fiscal Compact: Why the Left failed 52

$\begin{array}{ll}2.5 \text { Conclusion } & 61\end{array}$

3. Caught in the Changing Winds: A Reprieve for Social Europe 63

3.1 The Two-Pack: More of the same? 64

3.2 Edging towards Eurobonds: Does 'no mean 'no' for the Right? 82

$\begin{array}{ll}3.3 \text { Conclusion } & 99\end{array}$

4. European Elections 2014: An Unlikely Alliance Emerges 100

$\begin{array}{ll}\text { 4.1 Rise of the Eurosceptics } & 101\end{array}$

4.2 Europe's true believers: A series of grand coalitions 107

$\begin{array}{ll}4.3 \text { Conclusion } & 121\end{array}$

$\begin{array}{ll}\text { Conclusion } & 123\end{array}$

$\begin{array}{ll}\text { Bibliography } & 128\end{array}$ 


\section{Abbreviations}

AFD Alternative for Germany

ALDE Alliance of Liberal Democrats for Europe

CBER Centre for Economic and Business Research

CDU Christian Democratic Union

CEPS Centre for European Policy Studies

ECB European Central Bank

ECFR European Council on Foreign Relations

ECJ European Court of Justice

ECR European Conservatives and Reformists

EEC European Economic Community

EFA European Free Alliance

EFDD Europe of Freedom and Direct Democracy

EFSF European Financial Stability Facility

EMU Economic and Monetary Union of the European Union

EPP European Peoples' Party

ESM European Stability Mechanism

ETUC European Trade Union Council

EUCE Network of European Union Centres of Excellence

FDP Free Democratic Party (Germany)

FTT Financial Transactions Tax 


\section{Abbreviations (cont.)}

G8 Group of Eight

GCEE German Council of Economic Experts

GDP Gross Domestic Product

GFC Global Financial Crisis

GUE/NGL European United Left/Nordic Green Left

IMF International Monetary Fund

MEP Member of the European Parliament

MTO Medium Term Objections

OCA Optimum Currency Area

OECD Organisation for Economic Cooperation and Development

PASOK Panhellenic Socialist Movement (Greece)

PIIGS Portugal, Italy, Ireland, Greece and Spain

QMV Qualified Majority Voting

RQMV Reverse Qualified Majority Voting

SGP Stability and Growth Pact

S\&D Progressive Alliance of Socialists and Democrats

SDP Social Democratic Party of Germany

SYRIZA Coalition of the Radical Left (Greece)

TFEU Treaty on the Functioning of the European Union

UKIP UK Independence Party 


\section{Acknowledgements}

Well, then. Where to start? This is likely the closest I'll ever get to the award acceptance speech-type situation where they inevitably forget to thank someone. So here goes.

Huge thanks to my Mother and Father who have continued to support me through this all. I am now, and will forever be, extremely proud to have such brilliant people as my parents. Thanks to my awesome flatmates who make life in Wellington so much more worthwhile. Thanks to Milos, Madi, Kirsten, Carolyn and all the cool Canterbury kids for making me feel like less of a geek studying something like this. Still, let's be honest: Ich bin ein nerd.

More importantly, much gratitude to my supervisors John Leslie who introduced me to the fascinating world of EU politics with his great insight and enthusiasm, and Ben Thirkell-White who was terrific in guiding me through the hardest part at the end. This thesis is dedicated to my late Grandfather Michael O'Dwyer who will always be an inspiration, and to my incredible sister Ellen for helping me to believe in myself. 


\section{Introduction}

"Germany is our fatherland; Europe is our future"1

\section{- Helmut Kohl}

The idea of a united Europe was something only the great philosophers dreamed of, an ambition of which statesmen did not dare to speak until the devastating effects of the Second World War changed Europe's future for good. A "series of grand bargains" 2 set the continent on the path of evolving integration throughout the second half of the 20th century, until the fall of the Berlin Wall and the reunification of Germany cleared the way for the most extensive reversion of European economic treaties in history through the signing of the Maastricht Treaty and the creation of a European Union. ${ }^{3}$ This grand project, spurred on by the founding fathers of integration - Delors, Mitterrand and Kohl - expected much of an ever-expanding collection of nation states, many of which had had felt a severe human toll from their conflicting interests over past decades and centuries. While the Maastricht Treaty represented the greatest step forward in integration yet, much like the Treaty of Rome in 1957 it demanded more, and called for the creation of "an ever closer union among the peoples of Europe."4

The potential implications of an ever closer union, beyond the Economic and Monetary Union (EMU) and the single currency established in the 1990s, became the central focus for debate in Europe over the next two decades. Delors called for the realisation of a "true Federation" 5 , Kohl likewise dreamed of a "United States of Europe". Margaret Thatcher fiercely warned of dominance from Brussels and the

\footnotetext{
${ }^{1}$ Gray, T. and Wilke, S. (1996), German Unification and its Discontents: Documents from the Peaceful Revolution, University of Washington Press, USA, page 107.

2 Moravcsik, A. (1998), The Choice for Europe: Social Purpose and State Power from Messina to Maastricht, Cornell University Press, NY, USA, page 1.

${ }^{3}$ Van Oudenaren, J. (2004), “The European Union: From Community to Constitution", in Europe Today: National Politics, European Integration and European Security (ed. Tiersky, R.) Rowman and Littlefield Publishers, MD, USA, page 40.

${ }^{4}$ European Central Bank (1992) “The Maastricht Treaty: Treaty on European Union”, available: https://www.ecb.europa.eu/ecb/legal/pdf/maastricht_en.pdf

${ }^{5}$ Archer, C. (2008), The European Union, Routledge, Oxfordshire, UK, page 27.
} 
consequences of central power. ${ }^{6}$ Many of the disputes were based around the extent to which the European institutions and sovereign member states would influence economic policy-making. Disagreements over the issue materialised into three broad competing 'visions' for European integration: the move towards an ever closer union based on greater political unification and the consolidation of the EMU; the creation of a federalist 'Social Europe' based on full political and economic integration; and the Eurosceptic rejection of ever closer union calling for the repatriation of powers from Brussels to national parliaments.

The nature of the debate took a turn when the collapse of global financial markets and the disintegration of economies on the continent's periphery triggered the European Sovereign Debt Crisis in 2010. The devastating effects on the European economy caused policy-makers to reassess the idea of the EU and the competing visions of integration came under greater scrutiny than ever before. Many felt this was a time for a fundamental change; some saw the crisis as an opportunity to push their ideas for reform. The very foundations upon which the Union were based had been called into question while some observers believed it was only a matter of time before the single currency collapsed. Political leaders knew they needed to react; the question was how they would go about it. Jacques Delors had emphasised the need for Europeans to overcome national interests and individualism in the search for a common 'soul'. The events of the next four years in response to the crisis would do much to uncover the underlying nature of the soul of Europe.

This thesis analyses how the response to the Sovereign Debt Crisis has affected the strength of the three competing visions for Europe. It does so by focusing primarily on economic integration and by critically evaluating the political developments within three phases of the crisis between 2010 and 2014. Discovering the political soul of Europe is a crucial aspect in understanding the direction of the Union. Evaluating the strength of the competing visions will shed some light on Europe's future: will the Community exist simply as a collection of entirely sovereign nation

\footnotetext{
6 BBC News (April 8th, 2013), "In quotes: Margaret Thatcher", available: http://www.bbc.com/news/uk-politics-10377842
} 
states? Will we see the development of a transfer union under 'Social Europe'? Or will the EU even survive?

Chapter 1 sets the scene for the current narrative of economic reform by providing the background to both the Eurozone crisis ${ }^{7}$ and the historical development of the three visions in the $20^{\text {th }}$ century. It then examines the changing levels of support for the federalist and Eurosceptic ideals since the signing of the Maastricht Treaty in the early 1990s, and outlines the various political parties, member states, and other interests that have fallen in behind each of the three visions. It is concluded that despite the support in some quarters for a more collective approach to economic policy, and the low but ever-present levels of Euroscepticism, it was the German-led vision for a liberal economic 'stability union' with the most significant support and influence behind it prior to the crisis.

Chapter 2 focuses on the Fiscal compact, the most significant development in economic governance reform in Europe since the Stability and Growth Pact. Here it is shown how both Eurosceptics and Social Europeans failed to turn the tables against the German-led consolidation coalition which successfully sought to base economic governance reform around fiscal responsibility and tighter budgetary surveillance. Implications for the European treaties are discussed, with particular attention paid to the UK's decision to veto the agreement. The failure of the European Left is described as coming down to both concerns over the need to react and a lack of material power.

The following chapter looks at how a shift in the political climate in May 2012 altered the setting for debate as European leaders continued to strive for a solution to the crisis. A number of factors, including the election of Francois Hollande to the French presidency - and the corresponding end to the 'Merkozy' pact - as well as the deteriorating economic situation in the Eurozone, led to an increased uncertainty over the ability of austerity measures to solve Europe's problems. It is argued that the Two-Pack legislation for the most part followed the status quo direction set by prior consolidation-heavy reforms. However, the Left's ability to delay an agreement

\footnotetext{
${ }^{7}$ The terms 'Sovereign Debt Crisis' and 'Eurozone Crisis' are used interchangeably throughout this thesis
} 
while keeping the highly-controversial issue of Eurobonds in play acted as a major contributor to a turning tide against the austerity orthodoxy during 2012 and 2013.

Finally, Chapter 4 turns away from economic governance reform to look at the European elections of May 2014, where a strong rise in Eurosceptic sentiment caused a major stir across the continent. The cause for the surge in anti-EU votes is analysed and, while justifications including increased concerns over identity and a decline in trust of EU institutions are undoubtedly at play, explanations that downplay the role of economics are found to be unconvincing. The strong showing from Eurosceptic parties, particularly in the UK, France and Denmark, has provided an opportunity for those supporting a vision of 'less Europe' to capitalise on. However, it is argued that the most significant effect of the Eurosceptic rise could be the formation of an unlikely alliance of pro-integration forces. The paradoxical strengthening of the political establishment in Europe is likely to be of greatest benefit for the European Left, as the pressure to make discernable change away from the status quo in the Eurozone continues to mount.

Each of the visions for Europe is found to have enjoyed periods of support within the three phases of debate analysed in this thesis. Despite grave predictions and initial fears over the ability of the EU to stay intact, the commitment in the European political establishment towards an ever closer union has strengthened. This development has come to the detriment of the Eurosceptic vision, which has benefitted from a revival based on the success of nationalist and protest parties in the 2014 elections. While advocates of less Europe will seek to exploit uncertainty surrounding the implications of the Eurosceptic wave, it is more likely that the incoherent coalition opposing further integration will be crowded out by a much grander alliance between the centre-left and centre-right of European politics. With advocates of the two dominant visions agreeing on the need for a more ambitious $\mathrm{EU}$ in the wake of the crisis, the remaining question tackled in this thesis has been over the nature of economic reform. The ordoliberal orthodoxy so ardently supported by Germany and its allies has been the dominant economic ideology at play in the Eurozone, with stricter fiscal rules enforced and budgetary oversight 
enhanced in Brussels. However, an electoral turning point in 2012 provided the Left with a reprieve that would turn the tables against the consolidation coalition in European economic debate. While the effects of the changing political landscape following the 2014 elections are yet to be determined at the time of writing, this thesis argues that ever-building public frustration with the austerity-centric status quo in the EU will allow the Social European vision to prosper from the political establishment's new unlikely alliance. Europe is on course for another 'grand bargain' whereby Germany must choose between its commitment to its historic economic edifice and its dream of a European future. 


\section{The Sovereign Debt Crisis and Three Visions for Europe}

"The long drawn-out scream that can be heard reverberating around the dealing floors of the world, is the cry of the global economy plunging headlong over the edge of the precipice and into the abyss below."1

This was the brutal assessment of the global financial services giant UBS on October $6^{\text {th }}, 2008$, three weeks after the collapse of the American investment bank Lehman Brothers had confirmed that the bursting US housing bubble, crumbling global credit conditions and international bank bailouts were not merely points along the timeline of an extended economic blip, but key events that would combine to cause the greatest economic crisis since the Great Depression of the 1930s. Lehman Brothers' bankruptcy filing on September $15^{\text {th }}$ was the largest in US history and provided a "tectonic eruption that blew a gigantic hole in the world economy". ${ }^{2}$

The Global Financial Crisis would pull apart the European economy in a manner which few could have imagined. Moreover, it would lead citizens and policy-makers on the Continent alike to question the nature of an integration project which began over half a century beforehand. This chapter is broken into two distinct sections. First it will briefly discuss how the GFC led towards a crisis of devastating proportion that Europe could very much call its own, before outlining two explanations for the economic situation the Eurozone finds itself in today. The second section of this chapter sets up the three competing 'visions' for Europe dominating the political scene today. Two rival 'federalist' visions for Europe based on warring economic and political ideals are introduced as the dominant views in the debate since the formation of the EMU. Thereafter, the anti-integrationist vision is examined by explaining the development of Euroscepticism in the member states in the period leading up to the crisis.

\footnotetext{
${ }^{1}$ Paul Donovan, UBS (2008) "Recession". There is no alternative, available: http://www.youtube.com/watch?gl=GB\&v=27gGoplAQA\&hl=en-GB, (Accessed: May 20 2 th 2013 ) 2 McNally, D. (2011), Global Slump - The Economics and Politics of Crisis and Resistance, Spectre Publishing, Oakland, page 13.
} 


\subsection{Road to the crisis: How the great experiment failed}

The European economy had begun its decline a few months prior to the precipice of the sub-prime mortgage crisis in America. Euro area unemployment had risen 0.5 per cent between April and October in 2008 and a 1.1 per cent reduction in the growth rate between the first and second quarter in 2008 led to a contracting Eurozone economy for the first time in the history of the common currency. ${ }^{3}$ On the national level, things were even worse. By the end of the third fiscal quarter Germany, France, Portugal, Ireland, Greece and Spain had all officially entered recession - most of these countries for the first time in over a decade - and the rest of the euro area would be soon to follow.

\section{1.i The Sovereign Debt Crisis}

The Irish economy had dipped into recession during the early stages of the credit crunch, prior to any real concern of a global economic meltdown. This followed the greatest period of economic prosperity in the history of the Republic. From 1995 to 2008, the economy dubbed the Celtic Tiger had cast a magic spell on the emerald Isle. The nation saw over a decade of unprecedented growth, soaring employment and a poverty rate that dropped to below 6 per cent. ${ }^{4}$ By the start of the new millennium, the Bank of Ireland believed the nation to be the second richest in the world. ${ }^{5}$ While the majority of Irish economic officials and commentators had predicted the prolonged boom would end with a 'soft landing'6, the outcome was to be nothing less than a full-scale crash.

By the time Lehman Brothers had filed for bankruptcy, the Irish economy had already contracted for five of the past six quarters, over 50,000 more people had become unemployed and investors had stopped borrowing. ${ }^{7}$ Despite the negative trends, the Irish Government continued to insist that there was no disaster on the

\footnotetext{
3 "Euro Area GDP Growth", available: http://www.tradingeconomics.com/euro-area/gdp-growth (Accessed: May 20, 2013 ).

${ }^{4}$ Lewis, M. (2011), Boomerang: The Biggest Bust, Penguin Books, London, page 87.

${ }^{5}$ Ibid.

${ }^{6}$ Ibid, page 90.

7 "Ireland Unemployed Persons", available: http://www.tradingeconomics.com/ireland/unemployed-persons (Accessed: May 25 th , 2013).
} 
horizon and that the banks were in much greater condition than their American counterparts. This optimism proved to be unfounded. By January 2009, Anglo-Irish Bank and its losses of $€ 34$ billion had been nationalised and 10 months later, the Government created the National Asset Management Agency to buy $€ 80$ billion worth of bad bank assets. ${ }^{8}$ This happened amid an ever-shrinking economy, with an unemployment rate that had risen to over 12 per cent and a debt ratio close to three times greater than it had been at the end of the boom.

The Irish economy would soon be in need of external salvation, but not before Greece had ensured that rampant corruption and a false economy would cause it to become the main source of Eurozone concern. When George Papandreou came to power in October 2009, he found that the culture of tax evasion, bribery, dishonesty and excess had contributed to a dangerously poor economic situation, far worse than what had been reported. ${ }^{9}$ After an IMF investigation into the state of the country's finances had been completed, it was revealed the deficit/GDP ratio was five times larger than what had been previously declared. ${ }^{10}$

Greek government officials agreed that they would be forced to make large-scale cuts to the public sector in order to address the crisis but were held back by an evergrowing scale of stagnation and indebtedness. By April 2010, Greece was labouring under a budget deficit of 13.6 per cent of GDP and a debt/GDP ratio of 115 per cent. ${ }^{11}$ Unable to grow its way out of the situation, the only solution for saving the Greek economy and the Eurozone from the flow-on effects of its collapse would be a bailout. On May 2nd, Eurozone finance ministers and the IMF agreed to a $€ 110 \mathrm{~b}$ rescue plan for Greece, the largest bailout in history. Papandreou was forced to announce a heavy round of austerity measures in order for the country to meet its obligations to the EU. The cuts, directed almost entirely at the public sector, were

\footnotetext{
8 Ibid, page 117.

${ }^{9}$ Ibid, page 64 .

${ }^{10}$ Ibid.

11 "Greece - economic indicators", available: http://www.tradingeconomics.com/greece/indicators (Accessed: May 28 $8^{\text {th }}$ 2013).
} 
meant to save a staggering $€ 30 \mathrm{~b}$ by $2012 .{ }^{12}$ Public opposition to the austerity measures had been steadily building, and on May $5^{\text {th }}$, the anger among the masses marching on the streets of Athens reached its zenith, where three were killed and many more injured in a series of violent protests. ${ }^{13}$

Fears of European contagion that had surrounded the bailout negotiations and had frightened investors into submission would soon prove to be well founded. As the euro continued to falter throughout 2010, concerns that other member states would require bailouts intensified. After a period in which Irish debt had reached nearly 90 per cent of GDP and the country's unemployment rate had exceeded 14 per cent, the EU and IMF agreed to an $€ 85$ billion bailout for the country in late November; $€ 35$ billion of this would go towards propping up the failed banks. ${ }^{14}$ The remaining funds were designed to assist the government's budgetary needs and reduce the pain forced upon the electorate by the desperate state of the economy. Despite this, the Irish government passed a budget including the toughest spending cuts and tax hikes in the nation's history to counter what Finance Minister Brian Lenihan described as its worst ever crisis. ${ }^{15}$ Six months later Portugal became the next Eurozone member to receive a bailout, with an emergency loan package reaching $€ 78$ billion. ${ }^{16} \mathrm{~A}$ decision by finance ministers in February 2011 to create the European Stability Mechanism (ESM) ${ }^{17}$, a $€ 500$ billion permanent bailout fund to replace the

\footnotetext{
12 EurActiv (May 3rd, 2010), “Euro zone seals €110bn rescue plan for Greece”, available: http://www.euractiv.com/euro/euro-zone-seals-110-bn-rescue-plan-for-greece-news-493605 13 "Greek Bailout: Athens burns - and crisis strikes at the heart of the EU", available: http:// www.guardian.co.uk/world/2010/may/05/greek-bailout-economic-crisis-deaths (Accessed: May 29th, 2013).

${ }^{14}$ Lisa O'Carroll (November 28th 2010$)$, "Ireland bailout: full Irish government statement", available: http://www.theguardian.com/business/ireland-business-blog-with-lisaocarroll/2010/nov/28/ireland-bailout-full-government-statement ${ }^{15}$ Joe Brenan and Dara Doyle (December 9th, 2010), "Irish Lawmakers Back Budget to Combat 'Worst' Crisis", available: http://www.bloomberg.com/news/2010-12-08/irish-lawmakers-back-budget-aslenihan-battles-country-s-worst-crisis-.html 16 BBC News (May 17th, 2011), "Portugal's $€ 78$ bn euro bail-out is formally approved", available: http://www.bbc.co.uk/news/business-13408497 17 BBC News (February 14th 2011 ), "Eurozone agrees bailout fund of 500bn euros", available: http://www.bbc.co.uk/news/business-12460527
} 
more temporary EFSF, had not inspired much confidence that the light at the end of the tunnel was approaching. ${ }^{18}$

Discussion about the worsening economies in Spain and Italy, and the notion that the developing Sovereign Debt Crisis could spread beyond the periphery, kept an ominous cloud over the continent. As it became clear that Greece would require a second large bailout, European politicians - particularly in Germany and the UK began to voice the notion that a Greek exit from the euro would cause no more harm for Europe and Greece than the status quo. In July 2011, the forecasting agency CBER $^{19}$ claimed a 'Grexit' was inevitable and argued a complete breakup of the euro was almost certain within five years. ${ }^{20}$ The warnings of global economic peril at the outset of the GFC now found fresh impetus as the world looked on in horror at the European economy. With the common currency in crisis and the great experiment of European integration under increasing scrutiny it was difficult not to wonder how the union had failed so dramatically and why those in power had not seen this coming.

\section{1.ii Integration and the Maastricht Treaty}

Many believe the Eurozone's woes can be traced back to the foundation of Economic and Monetary Union (EMU) in Europe in the early 1990s. While the Treaty of Rome led to the establishment of the European Economic Community (EEC) in 1958, the Treaty was not explicit on macro-economic and monetary integration in Europe. It was predominantly aimed at creating the conditions for a common European Market and safeguarding economies within the community by ensuring equilibrium in Balance of Payments, confidence in currencies and a stable level of prices and

\footnotetext{
18 The ESM and EFSF have acted as the mechanisms through which the bailouts to Greece, Ireland, Portugal and Cyprus have been provided. The ESM operates as a transfer-facility-of-sorts whereby loans have been given to 'crisis countries' on the basis that they implement austerity measures to restore public finances. It is funded through a progressive system that calls on wealthier Eurozone member states to make the largest contributions.

Source: "ESM Shareholders", available:

http://esm.europa.eu/about/governance/shareholders/index.htm (Accessed: July 28th, 2014).

${ }^{19}$ Centre for Business and Economics Research

20 "The Euro: Greece is a sideshow", available: http://www.cebr.com/reports/the-euro-greece-is-asideshow-2/ (Accessed: 29th May 2013).
} 
employment. ${ }^{21} \mathrm{~A}$ decision in 1985 to complete the internal market by removing all physical, technical and fiscal barriers by the end of 1992 led to the signing of the Single European Act in 1986 and subsequently, the first concrete proposals for EMU in $1989 .{ }^{22}$ According to Willem Molle, the rationale behind monetary union was to smooth trade, thus contributing to the efficient allocation of resources. ${ }^{23}$ However the creation of the European Union at Maastricht in 1993 was about much more than engineering stable conditions for multi-national cooperation. The Maastricht Treaty was seen as a point along the continuum of European integration since the end of the Second World War, and - due to the commitment to EMU - the most significant point yet. The creation of a single currency and a monetary union were two of a series of measures constructed to bring people across the continent together under the common goal of European citizenship.

The Maastricht Treaty (formally the Treaty on the European Union) was signed on February $7^{\text {th }} 1992$ and came into effect in November 1993. ${ }^{24}$ The single currency would take over from the first day of 1999, with only Denmark, the UK and Sweden among the 14 states exempt from adopting the euro as the national currency. The opt-outs were one of the reasons why the Maastricht Treaty so quickly came under fire following its implementation. The two aforementioned countries, in addition to Sweden, Ireland and Poland refused to adopt certain parts of the Treaty, a factor which - in combination with significant issues passing the Treaty through national parliaments in Germany, the UK, Denmark and France - would cause debate over the supposed 'democratic deficit' in the newly formed Union. ${ }^{25}$ Others criticised Maastricht for reflecting not so much the universally desired ends of the European Community but the state of thinking within the dominant Franco-German engine in the early 1990s. ${ }^{26}$ The monetary union in itself has been almost universally derided by critics as either ill-conceived or ill-formed: a result of European bureaucratic

\footnotetext{
${ }^{21}$ Molle, W. (1997), The Economics of European Integration: Theory, Practice, Policy, Ashgate Publishing, Aldershot, page 404.

${ }^{22}$ Christiansen et al (2012) "Understanding and assessing the Maastricht Treaty" in: Journal of European Integration, vol 34, no. 7, Routledge, London, page 686.

${ }^{23}$ Molle, W. (1997), The Economics of European Integration, page 396.

${ }^{24}$ Christiansen et al (2012) "Understanding and assessing the Maastricht Treaty", page 687

${ }^{25}$ Ibid, page 690.

${ }^{26} \mathrm{Ibid}$, page 687.
} 
overreaching or a weak substitute for the full political and economic union required for effective integration.

The Eurozone crisis has led to much debate over the logic of creating a monetary union in the absence of the accompanying political infrastructure and enforcement mechanisms. ${ }^{27}$ Andre Sapir states that the Maastricht Treaty made no provisions for any genuine transferral of competence from the member states as well as including "no significant EU budget, no integrated financial supervision, no strong political counterpart to the central bank nor any provision for crisis resolution." 28 Caporaso and Kim agree that the most notable flaw in the Treaty was the creation of a common currency without provisions for an economic governance structure and sound banking regulations. ${ }^{29}$ Dyson questions the logic of this omission, arguing that the desire to keep fiscal and financial authority is actually incompatible with the objectives of having capital mobility and financial stability at the same time. ${ }^{30}$

This recurring argument describes the asymmetry best encapsulated by former chief economic advisor to Ronald Reagan, Martin Feldstein, who heavily criticised the provisions for monetary union in the Maastricht Treaty. Feldstein's main criticism was that the real rationale for EMU was political and not economic, despite the fact that there were considerable gaps and omissions on the political side of the Treaty. ${ }^{31}$ He warned that member states with vastly divergent economies would be tempted to leave the union should the shift to a single currency leave them in bad shape and the political arrangements of the union leave them unimpressed. ${ }^{32} \mathrm{He}$ also warned that the distributional effects of the single currency could be catastrophic, saying the

\footnotetext{
27 Ibid, page 693.

${ }^{28}$ Caporaso, J.A. and Kim, M. (2012), “The Maastricht Treaty at Twenty: A Greco-European Tragedy?" In: Christiansen, T. and Duke, S. (eds.) Journal of European Integration, Vol. 34, no. 7, Routledge, London, page 771.

${ }^{29} \mathrm{Ibid}$, page 775.

${ }^{30}$ Dyson, K. (2012), "Maastricht Plus: Managing the Logic of Inherent Imperfections", in: Christiansen, T. and Duke, S. (eds.) Journal of European Integration, Vol. 34, no. 7, Routledge, London, page 792 .

31 Feldstein, M. (1997) "EMU and International Conflict", in Foreign Affairs, Vol. 76, no. 6, Council on Foreign Relations, US, page 60.

32 Ibid, page 72.
} 
most likely outcome of the EMU "would be the growth of substantial transfers from the EU to countries that experience cyclical increases in unemployment". ${ }^{33}$

For others, it wasn't just the lack of fiscal and financial provisions where the treaty had failed. Some criticised the EEC for creating a monetary union with a single currency that was in itself unnecessary. John Gillingham argues that the economic rationale for adopting a monetary union in Europe was "anything but compelling". ${ }^{34}$ Like Feldstein, he claimed the "one size fits all" monetary policy would not be able to accommodate regional economic variations and that it would lead to a less efficient operation of the internal market. ${ }^{35}$ Moreover, Gillingham argued that Europe was not in a strong position to adopt a monetary union as none of the four pre-requisites - homogenous economies, flexible domestic wages and prices, labour mobility and responsive fiscal transfers - for an optimum currency area (OCA) were met. ${ }^{36}$ This view was shared by many other commentators, including The Economist, which called the Maastricht Treaty a "bungled design (that) ignored copious literature... and came up with three proposals that have nothing to do with optimum currency areas". 37

The European Commission and the Council had been frustrated over the lack of agreement over fiscal harmonisation to come out of Maastricht. Under pressure to enforce more budgetary oversight from Germany ${ }^{38}$, the Stability and Growth Pact (SGP) was adopted in 1998 and 1999 prior to the implementation of the single currency. The two most significant and well-known provisions in the agreement were the limiting of member states' budget deficits to 3 per cent of GDP and the restriction of debt levels to a maximum of 60 per cent of a country's GDP. ${ }^{39}$ Whilst it was hoped the SGP would reign in profligate spending and excessive borrowing and

\footnotetext{
33 Ibid, page 66.

${ }^{34}$ Gillingham, J. (2003) European Integration 1950-2003: Superstate or New Market Economy? Cambridge

University Press, NY, page 269.

35 Ibid.

${ }^{36}$ Ibid.

37 Ibid, page 274.

38 Feldstein, M. (1997) “EMU and International Conflict”, page 66.

${ }^{39}$ Morris, R. et al (2006), "The Reform and Implementation of the Stability and Growth Pact",

Occasional Paper Series no. 47, ECB, page 12, available:

https://www.ecb.europa.eu/pub/pdf/scpops/ecbocp47.pdf
} 
ultimately facilitate the stability of the EMU, the pact has failed in both its 'preventative' and 'dissuasive' aims and much like the monetary union, has been roundly criticised, primarily for its perceived excessively tight collar and an inherent bias towards price flexibility. ${ }^{40}$

Twenty years on from Maastricht, the evaluations of the Treaty as a whole have been mixed, with many conclusions on the monetary union nothing short of damning. Martin Feldstein has gained acclaim for essentially forecasting the Eurozone crisis over a decade before it took place. He has reiterated that the economic failure of the Treaty was "quite predictable" and that we're now seeing the results of an illadvised attempt to put a dozen (now 18) very different economies into a single currency with a single exchange rate. ${ }^{41}$

While it is easy to accuse commentators of revisionist history, it is clear that since the formation of the EU, there have been considerable concerns over the long-term compatibility of the EMU. American author Michael Lewis claims that it was obvious to a lot of people at the time of Maastricht that these countries did not belong together. ${ }^{42}$ Francois Mitterrand, French Prime Minister at the time, is said to have admitted in private that he knew the monetary union would lead to imbalances. ${ }^{43}$ Perhaps this is an indication of the risks which he and other European leaders were willing to take to achieve their ultimate goal. The Maastricht Treaty called explicitly for the evolution of a future political union. ${ }^{44}$ The goal was a European citizenship, a shared identity and a common future for all of Europe. ${ }^{45}$

\footnotetext{
${ }^{40}$ Dyson, K. (2012), “Maastricht Plus: Managing the Logic of Inherent Imperfections", page 800.

41 "Martin Feldstein on the future of the euro", available: http://www.youtube.com/watch?v=Vsqd_gOHmy8 (Accessed: May 29th, 2013).

${ }^{42}$ Lewis, M. (2011), Boomerang: The Biggest Bust, Penguin Books, London, page 168.

${ }^{43}$ Ibid.

${ }^{44}$ Feldstein, M. (1997) "EMU and International Conflict", page 60.

${ }^{45}$ Christiansen et al (2012) "Understanding and assessing the Maastricht Treaty", page 696.
} 


\section{1.iii Crisis countries: The scourge of Europe}

While the provisions of the SGP have been derided by many as unrealistic and the Maastricht Treaty heavily criticised for introducing an incomplete EMU, some believe the imbalances highlighted by the crisis were less the result of these factors than the outcome of poor political and economic management on the part of several member state governments. Whatever the existing economic discrepancies within the EU, proponents of this theory have argued that the now struggling PIIGS countries - chief among them Greece - have long been guilty of serious fiscal profligacy and the sort of political ineptitude that has prevented governments from enacting the necessary structural economic reforms to survive in the common market. ${ }^{46}$

Marsh suggests that some of these member states missed the boat in the years leading up to the crisis whereby - fairly or unfairly - the inability for governments to devalue under the single currency led to the necessary requirement of more stringent reform. He argues that, "the Euro has exposed shortcomings in economic policy among member countries that... need to be corrected by painful longer-term adjustments, through lower wage rises, increased working hours and job losses in uncompetitive businesses and sectors". ${ }^{47}$

Other academics and commentators have been less accommodating of the mistakes of peripheral member state governments, claiming those in charge of economic policy in the lead up to the crisis have only themselves to blame for the devastating outcomes of the Eurozone crisis. In regard to Europe's prime economic outcast in Greece, Featherstone points to the "endemic weaknesses of the state" 48 including "a political culture marked by clientelism, rent-seeking and corruption", alongside a

\footnotetext{
${ }^{46}$ Phillips, L. (2010) "Working the night-shift in the German austerity sweatshop - A primer on the crisis: Eurozone crash vs. United States of Europe", available:

http://euobserver.com/economic/31449

${ }^{47}$ Marsh, D. (2011), The Euro: The Battle for the New Global Currency, Yale University Press, Connecticut, page 4.

${ }^{48}$ Featherstone, K. (2011), “The Greek Sovereign Debt Crisis and EMU: A Failing State in a Skewed Regime" in Journal of Common Market Studies - Volume 49, issue 2, UACES, page 196.
} 
record of low reform capacity and consistently high levels of public debt. ${ }^{49}$ Lewis has highlighted the manipulation of economic data, tax fraud and insidious political corruption prevalent in Greece prior to the crisis as contributions towards "a society that has endured something like total moral collapse" ${ }^{50}$

It is not only Greece that has invited the displeasure of more economically sound member states within the EU. Weidmann and Panetta are among those who have also placed the blame for the crisis at the feet of states such as Ireland, Portugal and Spain. According to Bundesbank head Jens Weidmann, the governments of these countries failed to implement the necessary levels of consolidation and structural economic reform required to make the single currency work. ${ }^{51}$ Due to their inability to renounce welfare state objectives and adopt more realistic fiscal policy prerogatives, the excessive public debt held in Europe's periphery has not only affected the individual member states but the Eurozone economy as a whole. 52 Panetta agrees that the crisis was far from inevitable under the design of Maastricht, believing it was caused by "fiscal profligacy, weakness of the banking system and low competitiveness and productivity". ${ }^{53}$

Critics of the 'profligate periphery' have also lambasted a lack of action against misbehaving states at the institutional level in Europe. They note that with the SGP provisions in place, some countries falsified their accounts to satisfy the convergence criteria $^{54}$ and subsequently failed to consistently observe the rules while the European Council remained unwilling to enforce them. ${ }^{55}$ While few argue the design of the monetary union in Europe was perfect, and critics of the Maastricht Treaty are louder and more numerous than ever before, a stubborn group continue to insist that the rules were there for all to see at the outset, and that the dismal failure of a

\footnotetext{
${ }^{49} \mathrm{Ibid}$, page 198.

${ }^{50}$ Lewis, M. (2011), Boomerang: The Biggest Bust, Penguin Books, London, page 65.

${ }^{51}$ Jens Weidmann (March 28 ${ }^{\text {th }}$, 2012), "Rebalancing Europe", speech at Chatham House, London, available: http://www.bis.org/review/r120329a.pdf

52 Ibid.

53 Panetta, F. (2011), "Life in the Eurozone With or Without Sovereign Default", in: Allen, F. et al, European Commission Policy Report (of same title as chapter heading), page 11, available: $\mathrm{ftp}: / / \mathrm{ftp}$.cordis.europa.eu/pub/fp7/ssh/docs/sovereign_en.pdf

54Ibid.

${ }^{55}$ Ibid, 694.
} 
few to follow these rules contributed greatly to the collapse of the Eurozone economy.

After the initial shock of the Sovereign Debt Crisis and the desperation of nations trying to repair their broken economies, much of the debate in the Eurozone has turned to the question of 'who pays?' Peripheral economies, now trying to grow their way out of a crisis have become frustrated with Germany as they feel Angela Merkel's demands have placed them in an 'austerity straightjacket.'56 Many feel as though Germany has benefitted more from the Euro than any other nation and Greece, Spain, Cyprus and Italy have argued that German exports flooding into their countries has increased its prosperity at the expense of others. ${ }^{57}$ On the other hand, the German electorate has grown weary of the 'crisis countries' and is frustrated by the on-going bailouts offered by the ESM, for which Germany is the primary contributor. ${ }^{58}$ Lewis argued in 2011 that while the Eurozone was "conceived as a tool for integrating Germany with Europe, and preventing the Germans from dominating others, the euro had now become the opposite" ${ }^{59}$

In the context of the foundations of the monetary union it is crucial to note, however, that Germany was not dragged into EMU kicking and screaming. Whether they joined because they knew they would dominate economically and hold power over the ECB, or it was a decision made out of trust or a desire to exorcise a horrendous and divisive past, Germany wanted a union as much as other states needed it. This leads onto the central basis for the analysis in this thesis: the three visions for the future of Europe.

\footnotetext{
56 "Why does Europe resent Germany so much", available: http://www.cbc.ca/news/world/story/2013/04/23/f-pauls-berlin-germanophobia.html (Accessed: May 30th, 2013).

57 “The Poverty Lie: How Europe's Crisis Countries Hide Their Wealth", available: http://www.spiegel.de/international/europe/poor-germany-it-is-time-for-a-debate-on-euro-crisisburden-sharing-a-894398.html (Accessed: May 30th 2013).

58 "Will Germany's Bailouts save Europe", available: http://www.investopedia.com/financialedge/1112/will-germanys-bailout-save-europe.aspx (Accessed: May 30th, 2013).

${ }^{59}$ Lewis, M. (2011), Boomerang: The Biggest Bust, Penguin Books, London, page 144.
} 


\subsection{An ever closer union? The three visions}

The strong rhetoric and significant transfer of powers involved in the formation of the Maastricht Treaty had moved Europe further towards becoming a truly federalist supranational community ${ }^{60}$, and at the same time intensified the debate in around the evocative decades-old decree of an ever closer union. The Treaty of Rome had, in 1957, expressed a determination to move Europe towards this end. ${ }^{61} 36$ years later, Europe had become more integrated than ever under the Maastricht Treaty, with the creation of a common European citizenship, as well as monetary and political unions aimed at eventually encompassing the entirety of the continent. ${ }^{62}$

In the midst of the Sovereign Debt crisis, there have been three main European visions competing over the implications of an 'ever closer union' on economic integration, a battle that will undeniably shape the political soul of Europe for decades to come. In this section, I will explain these visions by discussing first their foundations, before examining the relative strength of support they each carried as the Eurozone crisis landed on the continent's doorstep. ${ }^{63}$

\footnotetext{
${ }^{60}$ While there is an ongoing debate over the extent to which the EU is a true 'federalism', this thesis takes the well-held view that the Union is at least a "species of federalism" - as McKay argues - and will not delve heavily into this particular discussion.

Source: McKay, D. (1999), Federalism and European Union: A Political Economy Perspective, Oxford University Press, UK, page 22.

${ }^{61}$ European Economic Community (March 25th 1957), The Treaty of Rome, page 2, available: http://ec.europa.eu/archives/emu_history/documents/treaties/rometreaty2.pdf 62 McKay, D. (1999), Federalism and European Union: A Political Economy Perspective, page 19.

${ }^{63} \mathrm{~A}$ much earlier representation of contrasting approaches towards European integration as a set of 'visions' was presented by Leon Lindberg in 1963. Lindberg's classifications differ from those in this thesis as he focussed only on pro-EU aims and did not seek to explain a 'Hard' Eurosceptic view on integration (though such an ideology was less popular during the years of 'permissive consensus' [see below] in which he was writing). He provides four broad visions - Integration as political unification, as economic unification, as economic and political cooperation and as free trade - and list a number of political parties and interests under the relevant groupings.

For more detail on Lindberg's visions see: Lindberg, Leon N. (1963), "The Political Dynamics of European Economic Integration", in: Eilstrup-Sangiovanni, M. (ed) (2006) Debates on European Integration, Palgrave Macmillan, Basingstoke, page 131.
} 


\section{2.i Germany's Europe: A coalition for consolidation}

The two dominant visions of the EU are federalist in nature. ${ }^{64}$ Both view the creation of the EMU under Maastricht as a major step towards deeper integration and eventual political unity. ${ }^{65}$ Supporters of both visions are active in promoting an ever closer union, though their plans for an ideal political and economic union in Europe contrast considerably.

Germany's influence in Europe is unmatched by any other member state, nor any other single political actor. The continent's most populous nation has been instrumental in the formation of the European Union: as Moravcsik argues, the most significant steps taken towards the creation of a European 'community' and political union have been engineered through a series of grand bargains between France and Germany. ${ }^{66}$ As such, the German vision for Europe has gained prominence, and acted as a particularly difficult obstacle for those with opposing agendas. Germany's Europe is best described as a centre-right, economically liberal 'coalition for consolidation'. The most dominant historical explanations offered to explain the German position towards an ever closer union come under two main themes: the nation's desire to discover a peaceful and prosperous Europe in the wake of reunification, and the creation of European monetary stability based on its deeply embedded 'ordoliberal' economic principles.

Germany has been an enthusiastic supporter of European integration from the very beginning of the project. ${ }^{67}$ After World War II, integration provided an unlikely vehicle for international recognition. Following the fall of the Berlin Wall and the reunification of Germany in 1990, foreign observers' concerns that a unified

\footnotetext{
${ }^{64}$ While both of the established pro-European visions are described here as federalist, there are different degrees of integration supported by each. Due to its commitment to political and economic unification, the Social European vision could be reasonably described as more closely reflecting the traditional understandings of federalism.

65 Umbach, G. and Wessels, W. (2008), "The Changing European Context of Economic and Monetary Union: 'Deepening', 'Widening', and Stability', in The Euro at 10: Europeanization, Power and Convergence (ed. Dyson, K.), Oxford University Press, UK, page 54.

${ }^{66}$ Moravcsik, A. (1998), The Choice for Europe: Social Purpose and State Power from Messina to Maastricht, page 4.

${ }^{67}$ Walsh, H. A. (2004), "Unified Germany: The Desire for Stability and the Need for Change”, in Europe Today, (ed. Tiersky, R.), Rowman \& Littlefield Publishers, MD, page 235.
} 
Germany might be less committed to Europe were proved to have been unfounded. ${ }^{68}$ Instead, the desire to further this recognition simply served to increase. According to Klaus Goetz, multilateralism - and the belief in the great value of the European political project - had become part of the German political elites' "genetic code" .69

This genetic code has greatly influenced the German approach towards economic integration and the creation of the single currency. The decision to embrace the euro, requiring Germany to give up the deutsche mark, was a deeply unpopular decision, in many respects due to the currency's association with the Wirtschaftswunder (economic miracle) of the post-war period. ${ }^{70}$ However, German public opinion was pulled away from the anxiety created by the deutsche mark's demise through a recognition of the symbolic importance the euro had acquired in the process of European economic and political unification. ${ }^{71} \mathrm{~A}$ passive but growing domestic consensus has since formed to support the fundamental 'rightness' of the euro as a political project ${ }^{72}$, due in part to its impact on post-war peace and prosperity. ${ }^{73}$

The ordoliberal dominance of German economic policy since the 1950s has had perhaps the biggest impact on the stability-based vision of Europe shared by Germany and its allies. Ordoliberalism - the German form of a 'social free market' or government-guided capitalist economy - became the dominant economic orthodoxy in West Germany under the influence of Finance Minister Ludwig Erhard after World War II. ${ }^{74}$ Drawing on the historical lessons of Weimar hyperinflation (post WWI) and of Nazi tyranny, ordoliberalism called for a limited but strong state that would deliver both economic stability and open, competitive markets. ${ }^{75}$ This

\footnotetext{
68 Ibid.

${ }^{69}$ Ibid.

${ }^{70}$ Dyson, K (2008), "Germany: A Crisis of Leadership in the Euro Area”, in: Dyson, K. (ed) The Euro at 10: Europeanization, Power and Convergence, page 160.

${ }^{71}$ Ibid, 161.

72 Ibid, page 133 .

73 Ibid, page 161.

74 David Henderson (2008), “German Economic Miracle”, available: http://www.econlib.org/library/Enc/GermanEconomicMiracle.html 75 Dulien, S and Guérot, U (2012), "The Long Shadow of Ordoliberalism: Germany's Approach to the Euro Crisis", page 2, available:
} 
approach to economic management found favour amongst the people and became intrinsically associated with the strong growth and low rates of inflation and unemployment that characterised the Wirtschaftswunder between the late 1940s and early $1970 s^{76}$

Ordoliberal economic orthodoxy has continued to influence both German domestic policy and the approach of successive governments towards Europe. The German influence over the creation of the monetary union can be described as an 'uploading' or 'binding in' of its policy preferences and institutional arrangements. ${ }^{77}$ Rules-based fiscal policy coordination in the Euro Area was secured in large part due to the activism of the Bundesbank in its preparations for the euro, especially through the 'Germanic' design of the ECB and its monetary policy.78 A reframing of the EMU in ordoliberal discourse thus took place. This was mostly allowed due to the dependence of the euro area's reputation on the performance of the German economy: the "centre of gravity" for Europe. ${ }^{79}$ A tacit sponsoring of ordoliberalism or at least a lack of opposition against this economic orthodoxy - on the part of centre-left and left-wing German political parties, combined with the inability of French and southern European economic models to resonate to the same extent, also left Europe without a legitimate alternative to the prevailing design of the EMU. ${ }^{80}$

As Chancellor from 2005, Angela Merkel gave top priority to fiscal consolidation in Europe. Germany had lost a certain amount of prestige on the Continent due to its economic woes and flaunting of the fiscal rules in the SGP it was so instrumental in creating. ${ }^{81}$ Merkel sought to restore Germany's reputation while using Europe as a chance to display her governing competence to the German electorate. ${ }^{82}$ The consolidation drive was not simply about pandering to a receptive German audience however. The Chancellor had found many friends in her pursuit of stability and

http://www.ecfr.eu/content/entry/the_long_shadow_of_ordoliberalism_germanys_approach_to_th e_euro_crisis

${ }^{76}$ David Henderson (2008), "German Economic Miracle"

77 Dyson, K (2008), “Germany: A Crisis of Leadership in the Euro Area”, page 136.

78 Ibid.

${ }^{79}$ Dyson, K (2008), “Germany: A Crisis of Leadership in the Euro Area”, page 132.

${ }^{80} \mathrm{Ibid}$, page 136.

81 Morris, R. et al (2006), “The Reform and Implementation of the Stability and Growth Pact", page 18.

82 Dyson, K (2008), "Germany: A Crisis of Leadership in the Euro Area", page 152. 
competitiveness in Europe during, particularly, her first term as leader. Merkel's vision was supported by the European Commission under both President Romano Prodi, and his successor José Manuel Barroso. ${ }^{83}$ Furthermore the consolidation coalition prior to the crisis encompassed northern European countries such as Finland and Belgium, as well as gaining the support of Luxembourg's Prime Minister Jean-Claude Junker, one of the prime architects of the Maastricht Treaty. Alongside various centre-right politicians and leaders around Europe, the Germanled alliance, to a significant extent, earned the backing of the largest political group in the European Parliament - the centre-right EPP-ED group - between 2004 and 2009.

However, the most crucial support for the German vision was found through the powerful alliance with France. While long-time French president Jacque Chirac had been criticised for his inability to maintain the Franco-German motor on European integration through his relationships with chancellors Kohl and Schroeder ${ }^{84}$, he enjoyed a strong bond with Angela Merkel in his final few years in charge, describing Germany's economic leadership as a "magnificent example." 85 The election of conservative Nicolas Sarkozy to the French Presidency in May 2007 resulted in a close relationship between the economically like-minded leaders and the Merkozy pact thereafter served to entrench the stability-based approach towards an ever closer union as the dominant vision in Europe.

\section{2.ii The European Left: Finding Social Europe}

The second of the dominant visions for the European Union, and the rival school of thought to the German-led consolidation coalition, is the ambition for a federal 'United States of Europe' marked by a fiscal and re-distributive transfer union. While Germany and its allies could be described as promoters of more conservative movements towards further economic integration - following their success in

\footnotetext{
${ }^{83}$ Romano Prodi (February $15^{\text {th }}, 2000$ ), "Shaping the New Europe", speech to the European Parliament, available: http://europa.eu/rapid/press-release_SPEECH-00-41_en.htm ${ }^{84}$ Reuters (May 3rd, 2007), "Chirac bids adieu to Merkel on final foreign trip", available: http://www.reuters.com/article/2007/05/03/us-france-elections-chirac-germanyidUSL0358245620070503 85 Ibid.
} 
embedding centre-right, liberal economic principles into the monetary union and Maastricht convergence criteria - the coalition's opponents seek an alternate view of 'more Europe', based on a more radical approach to economic and social policy. The pro-integration forces on the European Left - described interchangeably in this thesis as Social Europeans and as simply the European Left - are seeking a restoration of the European Social Model and the creation of a redistributive 'welfare state of welfare states' in order to overcome imbalances within the union. ${ }^{86}$ These two inter-related themes provide the background for the Social European vision of Europe.

The European Social Model is based on the recognition that social justice can, and should, contribute to economic efficiency and progress. ${ }^{87}$ The foundation of the Social Model can be traced to a "coevolution" between social democracy and European integration that, since the 1950s in some parts of Europe, sought to combat both Euroscepticism and the perceived 'capitalist club' dominance over European integration. ${ }^{88}$ However, unlike with the German ordoliberal foundations of the stability-based vision for Europe, there was a certain lack of consistency in attitudes towards integration among left-wing European parties, many of which remained in opposition for the majority of the post-war period due to the dominance of Christian Democratic parties over European politics. ${ }^{89}$ Some scholars such as Andre Sapir argue that there is no one European Social Model, but a number of variants across regions of Europe. ${ }^{90}$

Nevertheless, the move towards an ever closer union with the Treaty of Rome and creation of the common market heightened the enthusiasm towards solidarity on the

\footnotetext{
${ }^{86}$ Discussion or analysis of eurosceptic individuals, member states, political parties and groups of left-wing/socialist persuasion will be categorised as outside of the 'European Left' when necessary to avoid any confusion.

${ }^{87}$ Hemerijck, A. (2002), “The Self-Transformation of the European Social Model(s)", in: Esping, Andersen, G (ed) Why We Need a New Welfare State (ed. Esping, Andersen, Gosta), Oxford University Press, UK, page 173. ${ }^{88}$ McGowan, F. (2001), “Social Democracy and the European Union”, in: Mertell, L. (ed) Social Democracy: Global and National Perspectives (ed. Martell, L), Palgrave, NY, page 81.

${ }^{89}$ Liddle, R. (2008), "Is this the death of social democracy in Europe?" In: Lodge, G. et al (ed) Public policy research, Volume 15, Issue 3, page 111. ${ }^{90}$ Sapir, A. (2006), "Globalization and the Reform of European Social Models", in: Cini, M. et al (ed) Journal of Common Market Studies, Blackwell Publishing, Oxford, page 375.
} 
European Left. Further to this, the post-war period - characterised by the mostly Keynesian 'mixed' economic policy approach ${ }^{91}$ prescribing high levels of public investment and social protection - brought about a prolonged boom period in Europe, effective redistribution and a convergence of economic performance among states unlike anywhere else in the world. ${ }^{92}$

While Maastricht continued the evolution towards political unification on the continent, the creation of an EMU so heavily influenced by liberal economic principles and a stability pact characterised by fiscal rules and sanctions, threatened member states' protection of the Social Model. The Left's efforts to retain such a model at the European level were scuppered by a lack of action on the institutional front: whereas economic and monetary rules had been set in stone, directives for social protection were mentioned, but not mandated, in the post-Maastricht treaties..$^{93}$ The relative dismissal of social values contrasted with what many on the Left felt to be in the essence of being 'European' ${ }^{94}$ Social Europeans often argue that the generosity of the social model is what makes Europe different from any other region of the world. It is Europe's "attitude towards social solidarity" that creates a distinct identity from Asia and America. ${ }^{95}$

The European Left's commitment to protecting the Social Model leads onto the other primary and inter-related motivation behind their vision for Europe: namely its desire to create an egalitarian European welfare state through the foundation of a redistributive fiscal union. Those who share this vision see strong welfare states as "non-negotiable European realities" that define the people of the Union. ${ }^{96}$ However, the success of the right in dismantling welfare states through the free-market

\footnotetext{
${ }^{91}$ J. Bradford Delong (1997), “Post-WWII Western European Exceptionalism: The Economic Dimension", University of California at Berkely, available: http://www.j-bradforddelong.net/econ_articles/ucla/ucla_marshall2.html

92 Ibid.

${ }^{93}$ Taylor-Gooby, P and Larsen, Trine P. (2004), "New Risks at the EU Level; A Spillover from Open Market Policies?" In: Taylor-Gooby, P. (ed) New Risks, New Welfare: The Transformation of the European Welfare State, Oxford University Press, UK, page 181.

${ }_{94}$ Reid, T.R. (2004), The United States of Europe, Penguin, NY, page 150.

$95 \mathrm{Ibid}$, page 151.

${ }^{96} \mathrm{Ibid}$, page 150.
} 
structural adjustment period of the 1980s and 1990s, and the inability of the left to counteract this, ${ }^{97}$ have led Social Europeans to look towards Europe as their true solution to the welfare state.

Former French Prime Minister Lionel Jospin articulated the Social European vision by arguing for a Europe that "refuses to divorce economic prosperity from social progress"98 and for the acknowledgement of a European 'art de vivre' whereby a range of societal rights and freedoms are protected by the common whole. ${ }^{99}$ However, the Left in Europe feels as though the rights of citizens under the welfare state have been eroded under the EMU. The Maastricht criteria, it says, has forced countries to introduce policies designed to control public expenditure, particularly in the social field. ${ }^{100}$ Social Europeans claim the market-centric approach to economic integration has resulted in, and will continue to cause, more inequality among member states and European peoples. ${ }^{101}$

Moreover - while member states' abilities to react to social pressures have been constrained by an EMU based on strict fiscal rules - traditional welfare state taxation, spending and redistribution have remained largely outside the EU's domain. ${ }^{102}$ Social Europeans - who believe the extensive disparities in welfare among European regions becomes less and less acceptable as member states become more integrated are turning to Europe to defend their social commitments by altering the emphasis on stability and competitiveness. They believe a European "federation of nation states" with a much greater level of fiscal policy coordination and a co-ordination of taxes and benefits through collective agreements or an EU transfer body is the best way to restore and enhance the social model which is so crucial to their European vision. ${ }^{103}$

\footnotetext{
${ }^{97}$ Liddle, R. (2008), "Is this the death of social democracy in Europe?" Page 113.

${ }_{98}^{98}$ Jospin, L. (2002) My Vision of Europe and Globalization, Policy Network, London, UK, page 16.

99 Ibid, page 15.

100 Taylor-Gooby, P. et al (200), European Welfare Futures: Towards a Theory of Retrenchment, Polity Press and Blackwell Publishing, Cambridge, UK, page 159.

${ }^{101}$ Fouarge, D. (2004), Poverty and Subsidiarity in Europe: Minimum Protection from an Economic

Perspective, Edward Elgar Publishing, Cheltenham, UK, page 71.

102 Taylor-Gooby, P and Larsen, Trine P. (2004), “New Risks at the EU Level”, page 204.

${ }^{103}$ Ibid.
} 
Social Europeans today are made up predominantly by social democratic, centre-left or left-wing political forces including politicians in member state governments, MEPs and many in union movements across the continent. The $21^{\text {st }}$ century has brought with it a stronger consensus among social democratic parties as to the desirability of European integration, and the need for a federal, 'social' Europe.104 Prior to the crisis, supporters of this vision acted as the main counterweight to the institutional strength behind the German-led consolidation coalition. However, while there were a number of advocates for this vision at the beginning of the $21^{\text {st }}$ century among the 11 centre-left EU leaders, by 2008 only three prime ministers could be considered social democratic. ${ }^{105}$ Additionally, the left bloc in the powerstrapped European Parliament was inferior to the centre-right and liberal political groups sponsoring the ordoliberal economic orthodoxy of the EMU.

The European vision for social and economic solidarity had traditionally been an idea which had to a certain extent separated the southern states of Europe from the north. ${ }^{106}$ Despite the fact that there were only governments of the left in power in Spain and Portugal among the southern European member states prior to the GFC, the common Mediterranean approach to the welfare state and to economic integration in Europe meant that attitudes towards solidarity and the Social European vision were always largely positive in the region. ${ }^{107}$

\section{2.iii The Eurosceptic vision: 'No' to more Europe}

The expansion of European integration has, at each stage since the Community was formed, brought with it an outspoken opposition. The level, strength and cohesiveness of the Eurosceptic movement across the continent has fluctuated greatly since the 1950s, with the manifestation of certain 'sticking points', as well as the gradual enlargement of the Union after Maastricht playing a big part in the timing of anti-European fervour. While Euroscepticism has often been based on a

\footnotetext{
104 McGowan, F. (2001), "Social Democracy and the European Union", page 82. ${ }^{105}$ Liddle, R. (2008), "Is this the death of social democracy in Europe?" Page 112. 106 Rupnik, J (2006), “The European Union's Enlargement to the East and Solidarity”, in: Michalski, K. (ed) What hold Europe together? Central European University Press, Budapest, page 87. 107 Ibid.
} 
combination of socio-cultural, political and identity-related factors ${ }^{108}$, the foundation of the EMU served to shift the debate towards concerns over economic integration, where a vision for Europe based on the member states' retention of fiscal and monetary sovereignty was enhanced.

Although much of the literature surrounding Euroscepticism focuses on the postMaastricht period, its historical foundations lie in earlier stages of integration. ${ }^{109}$ The early period of anti-European sentiment was predominantly elite-driven and mostly nation-specific. ${ }^{110}$ Between the 1950s and 1990s, a 'permissive consensus' over integration based mostly on positive feelings over national economic performance ${ }^{111}$ shielded the influence of Eurosceptic minorities in a number of member countries. Opposition to integration swelled for the Social Democrats in Germany alongside the Gaullists in France in the 1950s; the Greek nationalists under Prime Minister Andreas Papandreou in the 1980s; and significantly in the UK under a Labour government seeking renegotiation in the mid-'70s, as well as under Margaret Thatcher's conservatives in the late 1980s. ${ }^{112}$

It has been argued that Euroscepticism prior to Maastricht was not particularly consequential, due to the fact that the European project at the time more closely resembled an international organisation than any form of political union. ${ }^{113}$ However it influenced the integration process as sceptics such as Charles De Gaulle were able to keep the transferral of powers to Europe in check, through early French dominance over the Community. ${ }^{114}$ While many modern Eurosceptics will find common ground with the Gaullists over the commitment to nation states, the term

\footnotetext{
108 Serrichio, F. et al (2013), "Euroscepticism and the global financial crisis", page 109 Vasilopoulou, S. (2013), "Continuity and change in the study of Euroscepticim: Plus ca change?" In: Cini, M. et al (ed) Journal of Common Market Studies, Volume 51, issue 1, Blackwell Publishing, UK page 158 .

110 Ibid.

111 Serrichio, F. et al (2013), "Euroscepticism and the global financial crisis", in: Cini, M. et al. (ed) Journal of Common Market Studies, Volume 51, issue 1, Blackwell Publishing, Oxford,page 53. 112 Vasilopoulou, S. (2013), "Continuity and change in the study of Euroscepticim: Plus ca change?" pages 158-159.

113 Ibid, page 159.

114 Ibid.
} 
'Eurosceptic' itself was born in Britain in the mid-1980s. ${ }^{115}$ This came during a period in which increased anxiety over the European project was fuelled by fears over the move towards a political and economic union, as well as Thatcher's nationalist rhetoric. ${ }^{116}$

The Iron Lady's interventions have played a big part in the nature of Euroscepticism in Britain today. However, it is true that the anti-integration phenomenon is not based on one ideology, political motive or historical understanding alone: rather, different individuals and groups within and between nations, political parties and protest movements under the Eurosceptic banner, hold a range of ideals for what 'Europe' should look like and to what extent a community should exist. ${ }^{117}$ This thesis touches on the development of a 'Eurosceptic vision' that seeks retrenchment from the powers given to Brussels coinciding with further involvement of national parliaments in European-wide decision-making. While some actors who support this vision would go as far to threaten a potential withdrawal from the EU, others are primarily focused on preventing the move towards an ever closer union.

The signing of the Maastricht Treaty allowed Eurosceptics to argue that the project had gone too far. They found a lot of support for this argument as the embedded nature of Euroscepticism in the integration process was revealed during the 1990s. ${ }^{118}$ The openly demonstrated desire on behalf of the political elites to transfer national competencies to the European level - in areas traditionally considered to belong to the realm of national politics such as foreign policy, citizenship and currency - had a

\footnotetext{
${ }^{115}$ Harmsen, R. and Spiering, M. (2005), Euroscepticism: Party Politics, National Identity, and European Integration, Rodopi Publishing, Amsterdamn, page 16.

116Vasilopoulou, S. (2013), "Continuity and change in the study of Euroscepticim: Plus ca change", page 158 .

117 For the sake of this thesis, the 'Eurosceptic vision' encompasses both 'hard' and 'soft' Euroscepticism, unless expressly separated in the text. Both forms oppose the status quo movement towards ever closer union but differ in the extent to which nations should pull away from the EU. This is best explained by Berglund et al. who distinguish "principled opposition to European integration" from "a sense that 'national interest' is currently at odds with the EU's trajectory". They do however note that in reality, the border between the two groupings is blurred and that some political actors defy classification.

Source: Berglund, S. et al (2006), The Making of the European Union: Foundations, Institutions and Future Theories, Edward Elgar Publishing, Cheltenham, UK, page 148.

118 Ibid, page 159.
} 
significant impact over popular opinion on integration. ${ }^{119}$ The negative referendum outcome in Denmark and the razor-thin 'yes' to Maastricht in France were followed by a series of EU opt-outs of social and economic integration for Britain, Ireland, Denmark and Sweden. ${ }^{120}$

It had become clear post-Maastricht that the public differentiated between political and economic integration and, to an increasing degree, did not favour the latter. ${ }^{121}$ Furthermore, Eurosceptics began to deride the EU for its 'democratic deficit' as they rallied against moves to take power away from national parliaments. ${ }^{122}$ The most common academic explanations for Euroscepticism include fears of losing national identity, a lack of trust in political institutions (extending to Europe) and as a "touchstone of dissent."123 However, the surge of Euroscepticism following the formation of the EMU casts doubts over justifications that downplay the role of economic rationale in anti-integration sentiment. The best analysis comes from McLaren, who concludes that two distinct paths to Euroscepticism - cultural threat and economic loss - are joined by the feeling of institutional distrust. ${ }^{124}$ She notes that levels of trust in both national and supranational institutions tend to go together, but that citizens' greater knowledge of their national governments leads to a 'better the devil you know' attitude, to the clear detriment of the EU.125

Euroscepticism fluctuated well above pre-Maastricht levels throughout the first decade of the $21^{\text {st }}$ century as 'no' votes in treaty referendums in France, the Netherlands and Ireland (twice) served to intensify the debate over the desired nature of Europe. However, it is important not to overstate the level of distaste for integration across the continent, while recognising the relative isolation of Euroscepticism to certain regions. The average proportion of European citizens against EU membership (between member states) reached a high of close to 18 per

\footnotetext{
119 Ibid.

${ }^{120}$ Ibid, page 160.

121 Serrichio, F. et al (2013), "Euroscepticism and the global financial crisis", page 53.

122 Vasilopoulou, S. (2013), "Continuity and change in the study of Euroscepticim: Plus ca change", page 159 .

123 Serrichio, F. et al (2013), "Euroscepticism and the global financial crisis", page 54.

${ }^{124}$ Hooghe, L. and Marks, G. (2007), "Sources of Euroscepticism", in Acta Politics, Volume 42, Palgrave Macmillan, page 123.

${ }^{125} \mathrm{Ibid}$, page 124.
} 
cent in 2007, and was 14 per cent in 2007 prior to the GFC. ${ }^{126}$ In the same year 58 per cent of those surveyed said membership in the EU was a good thing. While this represents a sizeable gap in pro and anti-EU sentiment across the Union, the picture has been much less clear cut in countries with traditionally high levels of Euroscepticism. Over 20 per cent opposed membership in the UK, Sweden, Finland and Austria in 2007, and in Britain it was only slightly below the proportion of respondents that supported it. ${ }^{127}$

Prior to the Eurozone crisis those supporting the Eurosceptic vision and seeking to block the move towards an ever closer union could see an opportunity to exploit wavering public sentiment towards the EU and its institutions. The most powerful voice against the EUs move towards an ever closer union since Maastricht has predictably been Britain. Tony Blair's opportunistic efforts to push his country towards adopting the euro came up against stern opposition in the form of an unreceptive Treasury, doubtful Chancellor of the Exchequer in Gordon Brown,128 and an even-less-negotiable state of public opinion. While the Labour government was in office, attitudes towards the single currency had remained predominantly negative coinciding with a whole scale lack of interest in the EU. ${ }^{129}$ Policies towards the EU subsequently became ever more negative with Brown replacing Blair in 2007 as Labour leader and PM.

But it wasn't only the UK drifting further towards a vision demanding less Europe. Seen predominantly as a 'British disease' during the expansion process of the 1990s ${ }^{130}$, levels of scepticism over the project of an ever closer union had firmed up in a number of other places prior to the beginning of the crisis. Views on the euro and further integration in Sweden were similar (if not slightly less severe), while governments in the Czech Republic, Finland and Denmark supported the vision to

\footnotetext{
126 Serrichio, F. et al (2013), "Euroscepticism and the global financial crisis", page 57.

127 Ibid, page 58.

${ }^{128}$ Buller, J. and Gamble, A. (2008), "Britain: The Political Economy of Retrenchment", in: Dyson, K. (ed) The Euro at 10: Europeanization, Power and Convergence, page 265.

${ }^{129}$ European Commission (2003), Eurobarometer 60: Public Opinion In the European Union, page 36.

130 Torreblanca, J. and Leonard, M. (2013), “The Continent-Wide Rise Of Euroscepticism”, European Council on Foreign Relations Policy Memo, London, UK, page 1, available: http://www.ecfr.eu/publications/summary/the_continent_wide_rise_of_euroscepticism207
} 
block an ever closer union while protecting national parliamentary sovereignty in a range of areas including fiscal, and sometimes monetary, policy. ${ }^{131}$ Despite this, there is little doubt that prior to the onset of the EU's first genuine economic crisis, the Eurosceptic vision was losing out to its competitors. The balance of power in European politics was in the hands of the Merkozy pact and the federalist base in Brussels. While Eurosceptic political parties existed in Germany and certainly in France, they were typically extremists who garnered low levels of support in national elections and thus had little influence over the nature of policies towards European integration (with the erstwhile exception of Jean-Marie Le Pen's National Front in France). ${ }^{132}$ This was also the case in many other European member states.

\section{2.iv Where to with the crisis?}

This second section of this chapter has explained the makings of three competing visions for Europe, as well as outlining their levels of support and relative strength prior to the start of the Eurozone crisis. The remainder of this thesis will seek to evaluate how major events in European governance and politics impacted on these competing approaches towards integration.

There are a number of assumptions that were made in European economic discourse about the likely impact of such a devastating crash. This chapter has already discussed the competing explanations for both the eventuation of the crisis and the creation of heavy economic imbalances within the Union. According to the conclusions summarised above either the naïve and incomplete design of the EMU, or the profligate fiscal behaviour of Europe's peripheral states were to blame for the state the Eurozone found itself in come 2010. But how would these explanations and the on-going effects of the economic devastation affect the success of the three overarching visions for the future of Europe?

As the severity of the crisis hit home in Europe, and the possibility of a Greek default remained on the table, the chance of a euro breakup was being talked up. This

\footnotetext{
131 Ibid, page 2.

132 Berglund, S. et al (2006), The Making of the European Union: Foundations, Institutions and Future Theories, page 153.
} 
represented the dream for 'hard Eurosceptics' searching for a return to entirely national dominion over all economic and social policy. ${ }^{133}$ Some commentators and academics believed breakup was a real possibility. As early as October 2008, Martin Feldstein listed a range of reasons a country might want to leave the EMU, in the wake of the effects of the GFC. He felt it was a genuine possibility that an economically strong country's desire for tighter monetary policy or the fear of moves towards a redistributive taxation union could lead governments to believe they were better off outside the single currency. ${ }^{134} \mathrm{He}$ also noted the possibility of weaker countries seeking exit, due to institutional constraints preventing Keynesian stimulus policies or the possibility of self-interested politicians exploiting anti-euro attitudes to move away from the EMU. ${ }^{135}$ In early 2010, prominent economist Paul Krugman claimed that Greece's economic situation could become so bad were it to default that the rationale for staying within the single currency may simply dissipate. ${ }^{136}$

However, the idea of a breakup of the euro, labelled "absurd" by ECB president Jean-Claude Trichet ${ }^{137}$ and "unlikely" and "overhyped" by the European Parliament ${ }^{138}$, was not a particularly popular idea in the minds of most academics and economists in 2010. It was, for the most part, a concept pushed by Eurosceptic forces in the media - such as in Britain's Daily Telegraph ${ }^{139}$ and the tabloids - seeking to counter the numerous calls for economic governance reform as a means to solve the crisis. While some dismissed claims that more Europe was needed to save the ailing Eurozone economy and prevent such a crisis from happening again, the

\footnotetext{
133 Ibid.

134 Feldstein, Martin (2008), "The Breakup of the Euro Area: Comment", NBER paper, available: http://www.nber.org/feldstein/breakupofeuroarea.html

135 Ibid.

136 Paul Krugman (April 28 th, 2010), "How Reversible Is the Euro?" available:

http:// krugman.blogs.nytimes.com/2010/04/28/how-reversible-is-theeuro/? php=true\& type $=$ blogs\& $r=0$

137 Adam Kritzer (March 24th, 2010), "A Break-Up of the Euro?" available:

http://www.forexblog.org/2010/03/a-break-up-of-the-euro.html

138 Whelan, K. (June $\left.8^{\text {th }}, 2010\right)$, The Euro, the ECB, and the Sovereign Debt Crisis, European Parliament,

Brussels, page 5. Available online:

http://www.europarl.europa.eu/activities/committees/studies.do?language=EN

139 Daily Telegraph contributors such as Roger Bootle Daniel Hannan (among others) have advocated for the breakup of the EU.
} 
prevailing feeling was that status quo Europe was the loser as something surely had to change.

The last six months of 2011 involved a constant stream of negative news for the European economy. Following a second Greek bailout, fears that Spain and Italy would be the next in line to receive assistance would not go away as the Italian Parliament passed an austerity budget set to save $€ 50$ billion by 2013. ${ }^{140}$ Throughout September and October, anxiety in Europe over the debt crisis heightened considerably. British Foreign Secretary William Hague labelled the Euro a "burning building with no exits" at a time when it seemed events were spiralling out of control. ${ }^{141}$ In order to put the fire out, policy-makers in Europe set upon improving the effectiveness of the EU and its institutions. The debate over the right vision for Europe in the midst of the crisis had just begun: was this the end for the federal, German-led liberal economic dominance over the Union? Or did the crisis provide the chance for the consolidation-coalition to re-emphasise the need for a more disciplined and stable political union? Some believed a radical change in economic governance was the only way forward. It was social and economic "federalism or bust" for Europe. ${ }^{142}$ The political debates, disagreements, compromises and collapses over a three-year period of reform would reveal much about the 'soul of Europe' moving into the future.

140 "Italy debt crisis: Austerity Bill sparks Rome clashes", available: http://www.bbc.co.uk/news/world-europe-14923915 (Accessed: May 30th, 2013). 141 "William Hague: Euro is a burning building", available: http://www.bbc.co.uk/news/uk-politics15098567 (Accessed: 30

142 Phillips, L. (2010) "Working the night-shift in the German austerity sweatshop - A primer on the crisis: Eurozone crash vs. United States of Europe" 


\section{The Fiscal Compact: Shaping the 'Austerity Union'}

When European leaders met on December the $8^{\text {th }}, 2011$ in Brussels for the latest episode in a long series of intergovernmental summits on the future of the Eurozone, most were late to arrive. The journey to Brussels had been made via Marseille, where Merkel, Sarkozy et al stopped off at the $20^{\text {th }}$ annual congress of the European People's Party, to placate the fears of centre-right politicians over a potential breakup of the Eurozone. ${ }^{1}$ They were also looking to draw attention away from externally expressed concerns: the US Government's demand that Europe get its act together and the threat of Standard \& Poor's to not only downgrade the EU's credit rating, but to do likewise for 15 of 17 Eurozone countries. ${ }^{2}$ Plans to strengthen fiscal surveillance and increase sanctions over profligate state spending were bound to be met well by the conservative audience in Marseille but earlier reports that a deal would not be close until Christmas served to increase the anxiety level of European parliamentarians. Merkel and Sarkozy upped the stakes by arguing that this was indeed a 'do or die' summit. On the other hand, Commission President José Manuel Barroso sought to bring a sense of calm to proceedings, "I believe this is possible... leadership is about making what is possible indispensable," he said. ${ }^{3}$

This chapter will discuss the most major piece of economic governance reform since the start of the Sovereign Debt Crisis: the Fiscal Compact. It will first examine the contention surrounding moves to enforce the pact within EU treaties and the failure of Britain to gain its own concessions in the agreement. It will note that the veto issued by David Cameron did not represent an overall victory for the Eurosceptic vision and likewise a loss for federalism, rather it predictably isolated the UK from Europe with little to show for it. Secondly, the chapter will chart the evolution of the European 'debt-brake', before evaluating how the European Left was thwarted in its scattered attempts to defeat a treaty which showed the strong influence held by the German-led consolidation coalition over the direction of economic reform.

\footnotetext{
${ }^{1}$ CBS news (December 8th, 2011), "EU leaders seek concensus; S\&P ups pressure", available: http://www.cbsnews.com/8301-500395_162-57339145/eu-leaders-seek-consensus-s-p-ups-pressure/ 2 Ibid.

${ }^{3}$ Ibid.
} 


\subsection{To treaty or not to treaty: All for one and one for all?}

The 27 leaders' meeting at the European Council HQ on this Thursday evening was preceded by a smaller meeting between Council President Herman Van Rompuy and the big three - Cameron, Sarkozy and Merkel - whose competing demands looked to be one of the main obstacles to a significant agreement being reached in Brussels. ${ }^{4}$ The French and Germans disagreed over whether a treaty change was necessary in order to form a legitimate pact, with Merkel steadfastly refusing to accept that any other option would be sufficient. ${ }^{5}$ Britain's primary concern was the preservation of the city of London as the European hub for financial services and Cameron was willing to do just about anything to protect his nations' interests in negotiations.

The French had been reticent over treaty change as they foresaw a series of difficulties in implementing such a reform. They worried about the expected involvement of European parliamentarians and the likelihood of referenda in several member states, which could cause significant difficulty. ${ }^{6}$ By the time negotiations got underway in Brussels, Sarkozy's government had decided to bow to their German allies on the necessity of a treaty. They were, however, unconcerned about the possibility of a treaty that did not include all 27 members - a preference for which Germany had advocated stridently - with some observers arguing such an approach was a means of alienating Britain from proceedings. ${ }^{7}$ The relationship with the UK government was at a low point, as French officials decried the hypocrisy of David Cameron seeking special protection for London while singing the praises of the single market. ${ }^{8}$

\footnotetext{
${ }^{4}$ Nicholas Watt and David Gow (December 9th, 2011), “EU summit: treaty changes on agenda as leaders meet", available: http://www.theguardian.com/world/2011/dec/08/treaty-changes-on-eusummit-agenda

${ }^{5}$ Ibid.

${ }^{6}$ Charles Grant (November 30th, 2011), "The French learn followership", available: http://www.cer.org.uk/insights/french-learn-followership

${ }_{7}$ Nicholas Watt and David Gow (December 9th, 2011), “EU summit: treaty changes on agenda as leaders meet"

${ }^{8}$ Charles Grant (November 30th, 2011), "The French learn followership"
} 
The French had actually long felt that a treaty among the 17 Eurozone countries alone might be the best course of action. Nicolas Sarkozy revealed his desire for a 'two-speed' Europe a month prior to the December Summit by arguing that true reform in the wider 27-member EU was not really possible and that, "in the end, clearly, there will be two European gears: one gear towards more integration in the euro zone and a gear that is more confederal in the European Union". ${ }^{9}$ Despite favouring the two-speed approach, Sarkozy clearly had less time for the views of those outside the Eurozone. He shouted down the plea of Danish Prime Minister Helle Thorning-Schmidt to enforce treaty changes at the level of 27 during the summit, saying, "You're an out, a small out, and you're new. We don't want to hear from you" ${ }^{10}$

Angela Merkel and Germany, on the other hand, believed the best way to achieve legitimate and legally binding economic governance reform in the EU was to have a full treaty change at the level of 27. She had been pushing a revision to the Lisbon treaty whereby national governments ceded more of their fiscal sovereignty to EU institutions, or at least would provide Brussels with more supervisory powers over member states' economies:11 "If we are talking about more Europe, more commitment and more ability for Europe to act, then we need to make sure that the conditions and pre-conditions are set out in the Treaties," the German leader argued. ${ }^{12}$

Meanwhile, David Cameron had reportedly indicated to his MPs prior to the conference that he expected Britain to gain major concessions in the negotiations over a new fiscal agreement. Whether he was kidding himself, bluffing other European leaders or simply presenting an air of confidence to placate Eurosceptic

\footnotetext{
${ }^{9}$ The Economist (November 10 th , 2011), "Two-speed Europe or two Europes?", available: http://www.economist.com/blogs/charlemagne/2011/11/future-eu

${ }_{10}$ Alex Parker and Geroge Barker (December 16 th 2011), "False assumptions underpinned British strategy", available: http://www.ft.com/intl/cms/s/0/6c5e100e-27ee-11e1-a4c400144feabdc0.html\#axzz1gyA9tA00

${ }^{11}$ Euractiv (September $8^{\text {th }}$, 2011), “Merkel calls for treaty change after positive court ruling", available: http://www.euractiv.com/euro-finance/merkel-calls-treaty-change-posit-news-507457 12 Euractiv (October 6 $\left.{ }^{\text {th }}, 2011\right)$, “Merkel: EU Treaty change should not be taboo", available: http://www.euractiv.com/future-eu/merkel-eu-treaty-change-taboo-news-508159
} 
colleagues, by the time an agreement was reached there was no doubting the union had found itself a new black sheep and the Eurosceptic vision had taken a hit.

\section{1.i The British Veto}

The optimism shown by Barroso and others leading up to the summit was vindicated in the early hours of Friday morning, the $9^{\text {th }}$ of December. European leaders were happy to leave Brussels with a roadmap for fiscal reform but the outcome came with a major setback. British Prime Minister David Cameron announced that he could not accept the terms of the agreement, thus issuing a veto which would prevent a united 27-member state pact and a thorough, legitimate alteration to the Lisbon Treaty. ${ }^{13}$

David Cameron had been fighting a European war at home against the increasingly Eurosceptic Conservative party rank-and-file, which urged their leader to oppose the terms offered at the summit unless special protection for the City of London could be obtained. The UK's demands did not go down well in Brussels. Cameron had sought considerable safeguards for London's financial services to be written into the treaty, including a demand that any transfer of power from a national regulator to an EU regulator would be subject to a veto, that the European Banking Authority remain in London and that the Treaty should block the ECB from ruling that all eurodenominated transactions take place within the Eurozone. ${ }^{14}$ The UK was essentially seeking a 'double-lock' mechanism over financial regulation, whereby London's prominence in this sector would be specifically recognised in the Treaty change and the Government would have the chance to refer any proposals it considered

\footnotetext{
${ }^{13}$ Nicholas Watt (December 9th, 2011 ), "Eurozone countires to go it alone with new treaty that excludes Britain", available: http://www.theguardian.com/business/2011/dec/09/eurozonecountries-treaty-exclude-britain

${ }_{14}$ Nicholas Watt et al. (December 9th, 2011 ), “David Cameron blocks EU treaty with veto, casting Britain adrift in Europe", available: http://www.theguardian.com/world/2011/dec/09/davidcameron-blocks-eu-treaty
} 
discriminatory to the European Council where it could block legislation with a veto. ${ }^{15}$

The UK's demands were partially based on the usual British Eurosceptic fear of ceding legislative control to Brussels. They were more concerned, however, that the Treaty changes would benefit the struggling Eurozone countries far more than those outside of the common currency. Close to 50 proposals to regulate the financial sector were in the offing 16 , including the broadly popular financial transactions tax (FTT), with Cameron and his cabinet allies suspecting an attempt from the Eurozone countries to pounce on Britain's competitive advantage in the sector. In the lead up to the summit, the importance of financial services to the UK's economy was highlighted by an open letter from $30 \mathrm{MPs}$ and Lords to The Telegraph arguing that an EU-wide FTT would "inflict enormous damage on Britain's economic interests" and that the Government needed to take "strong action" to overcome the "present drift (threatening) both British jobs and Exchequer revenues". ${ }^{17}$ There were widespread concerns in Westminster that the importance of the financial sector to the UK economy was being underplayed on the Continent. While some reports suggested that financial services made up only a small part of the economy, to the extent that it was perhaps not worth issuing a veto over, others claimed that the industry accounted for 10 per cent of Britain's GDP and generated over $£ 50$ billion in annual tax receipts while making up 36 per cent of the EU's wholesale financial industry. ${ }^{18}$

The primary elements of the proposed changes had little impact on Cameron's decision to veto, as it was well known in Europe prior to the summit that the UK had no intention of ceding control over its economic governance and being bound by the fiscal provisions in the treaty. The obligations contained within the agreement were

\footnotetext{
${ }^{15}$ Booth, S. et al (2011) Continental Shift: Safeguarding the UK's financial trade in a changing Europe, Open Europe, London, page 4, available: http://www.openeurope.org.uk/Content/Documents/Pdfs/continentalshift.pdf 16 Ibid.

17 Open Europe (December $8^{\text {th }}$, 2011), “30 MPs and Lords back our proposal for 'emergency brake' on financial services", available: http://www.openeuropeblog.blogspot.co.nz/2011/12/30-mps-andlords-back-our-proposal-for.html 18 Ibid.
} 
principally designed to coordinate and regulate fiscal policy within the Eurozone and contracting parties outside of the single currency would not be required to adhere to the provisions unless they declared an intention to be bound by them. ${ }^{19}$ Many believed Cameron had issued an unnecessary veto to cover for his inability to gain concessions. ${ }^{20}$ The Government was also lambasted for alienating itself from Europe and deserting their allies in such a time of need. Liberal Democrat politicians Lord Oakeshott and MEP Chris David derided David Cameron's move as "very dangerous", arguing he had "kicked (the European leaders) in the teeth" and cut Britain off from its "main trading partners... main allies (and) main friends." ${ }^{21}$ The Tories were unlikely to have been surprised by the level of criticism coming their way following the veto, however. There had been some reports prior to the summit that Cameron and his team had been hoping for some sympathy in their stance from the likes of Poland, Romania, Sweden and the Netherlands, all of whom were considered wary of a fragmented union resulting from the talks in Brussels. ${ }^{22}$ Furthermore, it was felt that given Cameron's stature as one of the 'big three' in the room, he may have been capable of using whatever goodwill he had to engineer the inclusion of a moderate measure to protect Britain's financial services. ${ }^{23}$

As it turned out, David Cameron and his government had limited goodwill going in to the summit. While many European leaders had fallen in behind Chancellor Merkel's demand that a Treaty be agreed among all 27 member states, the suggestion that the UK might veto without the inclusion of British-specific provisions caused frustration and dismay among the stakeholders. Polish Prime Minister Donald Tusk criticised those countries that were willing to put their national interest ahead of the needs of the union, saying it was a "devilish attitude...

\footnotetext{
${ }^{19}$ Michael Dougan and Michael Gordon (May 22nd, 2012), “Written evidence - Foreign Affairs Committee, UK Parliament", available:

http://www.publications.parliament.uk/pa/cm201314/cmselect/cmfaff/87/87we18.htm

20 Ibid.

${ }^{21}$ BBC (December 9th, 2011), "BBC Newsnight", available: http://www.youtube.com/watch?v=99DfZ98sEXI

22 Open Europe (December $\left.8^{\text {th }}, 2011\right)$, "What could Cameron hope for", available: http://www.openeuropeblog.blogspot.co.nz/2011/12/what-could-cameron-hope-for.html ${ }^{23}$ Ibid.
} 
(that could) lead to the ruin of the European community." 24 President-elect of the European Parliament Martin Shultz warned that any deal that involved horsetrading to meet country-specific demands could risk a larger fragmentation than the union was already exposed to. He suggested the leaders should perhaps think about “a 26-1 solution." 25

In the days following the December $9^{\text {th }}$ agreement, the UK's demands were publically dismissed out of hand. French President Nicolas Sarkozy claimed David Cameron's proposal was "unacceptable" as "a good part of the worries of the world comes from the deregulation of financial services". ${ }^{26}$ José Manuel Barroso said the protocol Cameron asked for "presented a risk to the integrity of the internal market" and thus made compromise impossible. ${ }^{27}$ He also implicitly criticised the British approach to the summit by stating his pleasure that "most member states made it clear that they do not want to circumvent the community method and the European institutions." 28 While the Cameron veto was predictably praised by a number of business leaders in London, the reaction from the Continent was one of disappointment in the inability to reach a 27-member agreement, and dissatisfaction with the UK over its self-interested demands.

The Prime Minister had hoped to use the threat of a veto to secure safeguards for the City of London but the momentum towards a fiscal pact due to the continued poor economic performance in the euro area and the billing of the negotiations as 'the summit to save the Eurozone', meant it was always unlikely leaders would look upon the UK's demand for protection with enough sympathy to compromise over core elements of the agreement. Cameron's tactics likely did more to hurt than help

\footnotetext{
${ }^{24}$ Open Europe (December $8^{\text {th }}$, 2011), "EU vs Eurozone: who said what ahead of the summit?" Available: http:/ / www.openeuropeblog.blogspot.co.nz/2011/12/eu-vs-eurozone-who-has-beensaying-what.html

25 Ibid.

${ }^{26}$ Nicholas Watt (December 9th, 2011), "Eurozone countires to go it alone with new treaty that excludes Britain"

${ }^{27}$ European Parliament (December 13th, 2011), "Counclusions of the European Council meeting [8-9 December], Debates - Plenary", available: http://www.europarl.europa.eu/sides/getDoc.do?pubRef=-//EP//TEXT+CRE+20111213+ITEM$005+\mathrm{DOC}+\mathrm{XML}+\mathrm{V} 0 / /$ EN\&language $=\mathrm{EN}$

${ }_{28}$ Ibid.
} 
advocates of less Europe. Instead of forming an alliance with sympathetic states over the extended reach of Brussels, the British demands came across as a self-interested stunt.

\subsection{A line in the sand: European Schuldenbremse}

The task set down at the Euro Summit of October 26, 2011 - to build a stronger economic union - was a target laid down before European leaders, on this occasion without a clear proposal or direction. While there were seemingly no formal papers making the rounds across the continent in the latter months of 2011, a Germaninspired budgetary-crackdown for the euro members was the main idea in question. Such an idea took very much the same approach as that endorsed by leaders through the signing of the Six-Pack. The first reform to economic governance of note - set to officially come into force in December 2011 - introduced six 'legislative acts' aimed primarily at ensuring a stricter implementation of the SGP. ${ }^{29}$ This would be achieved by making it harder for Eurozone countries to ignore warnings from the Commission; by fining misbehaving governments for the release of fraudulent statistics; by requiring that member states' budgets converge towards countryspecific medium-term objectives; and by applying the Excessive Deficit Procedure to debt above 60 per cent of GDP.

While there were a few notable holdups ${ }^{30}$, the new legislation passed with strong approval from the vast majority of political actors in Brussels - and from the member states - as leaders desperately sought to stop the Eurozone economy from bleeding out. Moreover, the process re-emphasised the extent to which power in the EU lay with Germany and its allies supporting the consolidation-centric vision for Europe. Despite this success, few European policy-makers believed the Six-pack rules could by themselves restore the state of the Union. Instead, they were seen as just a 'first step' in the process of reform. While Angela Merkel urged the adoption of stronger powers for the EU to act against fiscal profligates, Guy Verhofstadt -

\footnotetext{
${ }^{29}$ Verhelst, S (2011), The Reform of European Economic Governance: Towards a Sustainable Monetary Union? Academia Press, Gent, Belgium, page 39.

30 Euractiv (September 29th, 2011), "EU ratifies crisis makeover to Stability and Growth Pact", available: http://www.euractiv.com/euro-finance/eu-ratifies-crisis-makeover-stab-news-507996
} 
leader of the liberal European Parliament group ALDE - argued the agreement should make up only part of a future "comprehensive framework for economic governance and growth". ${ }^{31}$

Mid-way through 2009, before the Sovereign Debt Crisis had even begun in earnest, German legislators passed a bill that would require the country to run a fiscal deficit of no more than 0.35 per cent of GDP, with deficits becoming completely illegal from the year 2020.32 A year later, with economic conditions consistently worsening and public debt blowing out to previously unimaginable levels, the Germans would ask their European brothers and sisters to follow suit. Finance Minister Wolfgang Schäuble's suggestion predictably received a mixed reaction across the Continent, but was quickly backed by the Austrian Government and more importantly found favour with Nicolas Sarkozy. ${ }^{33}$ This was truly a sign of the times - an acknowledgement of the need for desperate measures - as a constitutional balanced budget provision, known as Schuldenbremse in Germany, would have almost certainly sent European leaders up the walls if it were proposed a mere 12 months earlier.

Merkel and Sarkozy had previously joined forces over the idea of a European Schuldenbremse prior to negotiating the March 2011 agreement for the Euro Plus Pact: a watered down set-back for the Franco-German crackdown on fiscal profligacy, with the 'debt-brake' taken off the table. Both leaders stayed true to the principle however, and returned with another proposal for constitutionally mandated balanced budgets five months later. After talks in Paris on August 17th, Merkel and Sarkozy expressed their desire to strengthen the euro by introducing the debt-brake, asking all 17 countries of the single currency to "adopt the golden rule in writing in

\footnotetext{
31 Ibid.

32 Wolfgang Munchäu (June 21st, 2009), "Berlin weaves a deficit hair-shirt for us all”, available: http://www.ft.com/intl/cms/s/0/4e63cb22-5e8b-11de-91ad-00144feabdc0.html\#axzz2fDIzjxi7 33 Ibid.
} 
their Constitutions, the rule that national budget laws are aimed at achieving a balanced budget. "34

While the idea copped criticism from certain quarters of the European media, it emerged that both Italy and Spain would support the mechanism, with the Berlusconi government already having announced a national policy to add a similar amendment to its constitution, and with Spain agreeing upon the necessity for such a move for the sake of the Eurozone. ${ }^{35}$ The support from the two largest southern European countries, not often seen as natural allies to the Franco-German alliance, was crucial following earlier pronouncements of support from the likes of Poland and Austria. ${ }^{36}$ By the time the 'Summit to end all summits' came around on the $8^{\text {th }}$ of December, Schuldenbremse had sustained momentum, and Council President Herman Van Rompuy had put the proposal on the table. The support from all ends of Europe over such a stringent budgetary measure underlined the extent to which the ordoliberal orthodoxy had remained in the ascendancy through the early crisis years. Countries with high levels of debt such as Italy and Spain felt it was futile to go up against the powerful austerity-inspired Franco-German engine under the control of the Merkozy pact.

A report from Van Rompuy, leaked to the media prior to the summit, set down two possible avenues to move towards a "new fiscal compact". ${ }^{37}$ The debt-brake amendment could be added via a "substantial revision" of Protocol No. 12 of the TFEU - the excessive deficit procedure - by way of an "obligation for euro area Member States to reach and maintain a balanced budget over the economic cycle". ${ }^{38}$

\footnotetext{
34 Open Europe (August 17th, 2011), "The day after the night before", available: http://www.openeuropeblog.blogspot.co.nz/2011/08/day-after-night-before.html ${ }_{35}$ Andrew Watt (August 26 $6^{\text {th }}, 2011$ ), "Inane in Spain: debate on terms of debt brake begins", available: http:// www.social-europe.eu/2011/08/inane-in-spain-debate-on-terms-of-debt-brake-begins/ ${ }^{36}$ Leigh Phillips (February 23rd, 2011), "Poland backs Franco-German pact, but wants in on talks", available: http://euobserver.com/economic/31861 (Poland) and, Daniel Schäfer and Ben Hall (May $\left.16^{\text {th }}, 2010\right)$, "Berlin calls for Eurozone budget laws", available: http://www.ft.com/intl/cms/s/0/5ff35db4-6117-11df-9bf0-00144feab49a.html\#axzz2ShRBzjot (Austria).

${ }^{37}$ Van Rompuy, H. (6 December, 2011) Towards a Stronger Economic Union - Interim Report, Brussels, page 2, available: http://blogs.ft.com/brusselsblog/files/2011/12/INTERIM-REPORT-FINAL-6-12. $\mathrm{pdf}$ 38 Ibid, page 3.
} 
The amended Protocol would "also include the obligation for euro area Member States to include such a rule in their national legal systems, preferably at constitutional or equivalent level". ${ }^{39}$ Van Rompuy felt the way to enforce this was through the Court of Justice having "jurisdiction to control the transposition of this rule at a national level" and that the rule be complemented by automatic correction mechanisms (automatic increases in revenues and reductions in expenditure to aid states to meet the provision). ${ }^{40}$ The firm backing of a European Schuldenbremse from Van Rompuy followed on from José Manuel Barroso's open support for the FrancoGerman plan in August ${ }^{41}$, leaving no doubt to the weight of institutional support behind this fundamental fiscal crackdown.

On December 9th, following the lengthy negotiations, the 17 Euro Area heads of state and Council President Herman Van Rompuy released statements decreeing the success of the Summit in producing "a move towards a stronger economic union". ${ }^{42}$ The agreement on the debt-brake required that "general government budgets shall be balanced or in surplus" and that this rule would be "deemed respected if... the annual structural deficit does not exceed 0.5 per cent of nominal GDP". ${ }^{43}$ The obligations for states to introduce the rule into their national constitutions - verified by the European Court of Justice (ECJ) - and to enable automatic correction mechanisms were also written into the text. ${ }^{44}$ While the stable 0.5 per cent deficit requirement was more lenient than in the German Schuldenbremse, it was barely so, and it certainly did not appear a let-off for Eurozone members considering almost all states were running budget deficits at a considerably higher level than $0.5 \%$ of GDP.45 Due to the expressed 'veto' from the UK and the resulting "absence of

\footnotetext{
39 Ibid.

40 Ibid.

41 Stefan Simons and Carsten Volkery (August 18, , 2011), "'Pure Symbolism': The Great Debt-Brake Swindle", available: http://www.spiegel.de/international/europe/pure-symbolism-the-great-debtbrake-swindle-a-781069.html

42 European Council (December 9, 2011), Statement by the Euro Area Heads of State or Government, available: http://www.consilium.europa.eu/uedocs/cms_data/docs/pressdata/en/ec/126658.pdf, page 1.

43 Ibid, page 3.

44 Ibid.

45 Eurostat, "Government revenue, expenditure and main aggregates" (last update: May 14th, 2014), available:
} 
unanimity among the EU Member States", the text noted that the fiscal compact would be brought in via an intergovernmental agreement to be signed in March. ${ }^{46}$

There was a slightly surprising momentum for the balanced budget provision, giving the impression that the new fiscal rule would go through seamlessly and without too much protest. Despite the controversy of such a strict imposition on states, the feeling was that the economic situation in Europe was so dire that drastic action had to be taken. However, the failure of the pact to prevent national referenda and a shift in political sentiment in France with the election of Francois Hollande as President, meant the ratification of the Fiscal Compact would require much more than a mere tying up of loose ends.

\subsection{Blocking the pact: Sovereign democracy and the European left}

Herman Van Rompuy had confidently predicted the Fiscal Compact would receive near unanimous support when it came to signing the agreement into law. "26 leaders are in favour of this effort," he said after the December agreement. "They recognise the euro is a common good." 47 The former Belgian Prime Minister was however, a little too quick to assume such an unbridled success. Immediately after the December Summit it had become clear that several countries felt they would need to consult their national parliaments prior to signing the Treaty. ${ }^{48}$ While this would be a formality for most, the fact that many of the non-Euro area countries had not quite jumped into the agreement with the gusto of the leading players inside the Eurozone raised further concerns for the pact's legitimacy, against the backdrop of whispers over the creation of a multi-speed Europe.

http://appsso.eurostat.ec.europa.eu/nui/submitViewTableAction.do;jsessionid=9ea7d07d30d6e9d8f 9fbb7f54a8d9711ae083b1cfcec.e34OaN8PchaTby0Lc3aNchuNa3uQe0

${ }^{46}$ European Council (December 9, 2011), Statement by the Euro Area Heads of State or Government, page 7.

${ }^{47}$ Herman Van Rompuy (December 9th, 2011), Remarks of Herman Van Rompuy, President of the European Council, following the meeting of the European Council, page 1, available:

http://www.consilium.europa.eu/uedocs/cms_data/docs/pressdata/en/ec/126712.pdf

${ }^{48}$ Euractiv (December 15th, 2011), "Europe's new treaty: Towards a multi-speed Union", available: http://www.euractiv.com/future-eu/europes-new-treaty-multi-speed-u-linksdossier-509753 
In the days and weeks following the December summit, Poland, the Czech Republic, Sweden and Denmark were all cautiously holding fire on supporting the treaty, with many of those countries expressing fears that the new powers given to Brussels to police national budgets would be binding to signatories outside of the Eurozone. ${ }^{49}$ The Prime Minister of the Czech Republic criticised the vague nature of the deal and said: "It would be politically short-sighted to come out with strong statements that we should sign this piece of paper." 50 Doubts over Sweden and Denmark would prove unwarranted as their parliaments approved the adoption of the Fiscal compact fairly comfortably. ${ }^{51}$ The Czech Republic though, initially refused to join the pact, as the government feared a loss of fiscal sovereignty and was unable to secure the concession of a seat at the newly created bi-annual Eurozone summits. ${ }^{52}$

The real threats to Europe's 'stability union'53 were however in the Eurozone, in Ireland and increasingly in France. In the days after the December agreement, it quickly became clear that the Irish public would demand a referendum on the Fiscal Compact and that the Government would find it difficult not to oblige them. The two main opposition parties - Fianna Fáil and Sinn Féin - demanded Taoiseach (Prime Minister) Enda Kelly put the new treaty to a popular vote, a move which some felt would almost certainly lead to an Irish rejection of the pact. ${ }^{54}$ In late February, days before the Fiscal Compact was to be signed by 25 countries including Ireland, Kelly announced that a referendum would indeed be held before the treaty

\footnotetext{
${ }^{49}$ Kate Mackenzie (December 14 $\left.4^{\text {th }}, 2011\right)$, "EU treaty hopes come under strain", available: http://ftalphaville.ft.com/2011/12/14/798121/eu-treaty-hopes-come-under-strain-2/ 50 Ibid.

51 EUbusiness (31 ${ }^{\text {st }}$ May, 2012), "Denmark and Sweden ratify EU fiscal pact", available: http://www.eubusiness.com/news-eu/denmark-sweden-debt.gs6 and Warsaw Business Journal (February 2nd, 2012), "Poland on course to ratify EU fiscal compact", available: http://www.wbj.pl/article-61981-poland-on-course-to-ratify-the-eus-fiscal-compact.html ${ }^{2}$ EUobserver (January 30th, 2012), "Czech Republic stays out of new fiscal treaty", available: http://euobserver.com/tickers/115079

${ }^{53}$ Honor Mahony (September 7th , 2011), "Merkel outlines steps to 'stability union'", available: http://euobserver.com/political/113550

${ }^{54}$ Joshua Chaffin et al. (December 13 ${ }^{\text {th }}, 2011$ ), "EU treaty hopes come under strain", available: http://www.ft.com/intl/cms/s/0/3d75ccb8-25b5-11e1-856e00144feabdc0.html?siteedition=intl\&siteedition=intl\#axzz1gUv1tigO
} 
was ratified in the Republic. ${ }^{55}$ The decision came as a surprise in certain quarters as it was assumed the government was doing everything it could to argue against the legal necessity of ratification via a popular vote. However the Attorney General had decided that 'on balance' the calls for a referendum were legitimate, despite the intergovernmental nature of the treaty. ${ }^{56}$ The initial reaction across the Continent was one of quiet disappointment as treaty protagonists had felt that the pact was designed in order to avoid such a referendum from taking place. ${ }^{57}$ Leftist Republican and leader of the opposition Gerry Adams confidently predicted the treaty would be defeated and the government embarrassed but the vote was set to be close. ${ }^{58} \mathrm{~A}$ January poll suggested the treaty would narrowly pass with 40 Per cent of those questioned saying they would vote 'yes'. Another 36 per cent opposed the treaty, while a quarter of voters were undecided. ${ }^{59}$

On May 31st, the referendum passed as 60 per cent voted to ratify the Fiscal Compact. ${ }^{60}$ For once, the 'no' campaign in Ireland had failed the first time around. The collective sigh of relief from Brussels and Berlin could almost be heard across the Continent, not least due to the fact that there would be no need for any offering of concessions to Ireland on this occasion. While a third abstaining nation would have been far from ideal, and put more pressure on Europe's power-brokers over the pact's legitimacy, there had been a consensus growing that a 'no' vote in Ireland would do the Republic more harm than it did to the EU. ${ }^{61}$ However, while many of the objections cited throughout the referendum process in Ireland were not over details of the Fiscal Compact itself, the calls from anti-treaty campaigners to

55 Thejournal.ie (February 28 2 th 2012 ), “Government confirms referendum on EU fiscal compact treaty", available: http://www.thejournal.ie/government-confirms-referendum-on-eu-fiscalcompact-treaty-368394-Feb2012/

${ }^{56}$ Ibid.

57 Joshua Chaffin et al. (December 13"th 2011), "EU treaty hopes come under strain" 58 James O'Shea (February 28 $8^{\text {th }}, 2012$ ), "Irish must hold referendum on new European treaty", available: http://www.irishcentral.com/news/Irish-must-hold-referendum-on-new-Europeantreaty-140758663.html

${ }^{59}$ Euractiv (February 29th, 2012), "Ireland calls referendum on EU fiscal treaty", available: http://www.euractiv.com/euro-finance/ireland-calls-referendum-eu-fisc-news-511184 ${ }^{60}$ The Economist (June 2nd, 2012), "Irish ayes: Ireland's referendum on the fiscal compact", available: http://www.economist.com/blogs/newsbook/2012/06/irelands-referendum-fiscal-compact ${ }^{61}$ Bruton, J. TD (March 26, 2012) The Fiscal Compact Treaty - The Choice The Irish People Have To Make, speech to the Malahide branch of Fine Gael, available: http://transatlantic.saisjhu.edu/publications/articles/Bruton\%20Irish\%20Referendum.pdf 
renegotiate the terms of the agreement reflected a growing surge of displeasure with the deal among the political left in Europe.

After the final details of the Fiscal Compact were set down in January, the European Trade Union Confederation (ETUC) had summoned a meeting of Union leaders from across Europe in Brussels to protest the terms of the agreement. ${ }^{62}$ In a declaration released on January $25^{\text {th }}$ the ETUC fiercely criticised the treaty for its "more of the same" approach which led Europe down the path of austerity and budgetary discipline "giving absolute priority to rigid economic rules at a time when most economies are still weak and unemployment intolerably high". ${ }^{63}$ The Union leaders demanded a wide-ranging European treaty on economic governance include a stronger mandate for the ECB as a lender of last resort, an EU-wide financial transaction tax, a partial pooling of debt through Eurobonds, a wage safeguard clause, a social progress protocol and significant protocols to safeguard growth. ${ }^{64}$ Furthermore they condemned Germany and its allies for imposing "wrong and socially harmful" initiatives on other European countries. ${ }^{65}$

The Irish 'no' campaign opposed the treaty along similar lines. As the Irish had initially vetoed the treaties of Nice and Lisbon, in 2001 and 2008 respectively, there was optimism on the Left for a repeat with the Fiscal Compact. The Socialist Party expressed the Social European view perfectly. "The European political, financial and business establishment want to enshrine in law across Europe the type of policy response to the crisis that we have already seen fail across Europe", they said. ${ }^{66}$ They also claimed that the need to meet a 0.5 per cent structural deficit target would mean an additional $€ 6$ billion in extra cuts to the Irish budget, only adding to the

\footnotetext{
${ }^{62}$ Euractiv (January 26 $6^{\text {th }}, 2012$ ), "Trade unions plan pan-EU action against fiscal compact", available: http://www.euractiv.com/socialeurope/trade-unions-plan-pan-eu-action-news-510386

${ }^{63}$ European Trade Union Confederation (January 25th, 2012) ETUC declaration on the Treaty on stability, coordination and governance in the economic and monetary union, page 2, available:

http://www.etuc.org/IMG/pdf/EN-Declaration-on-the-new-treaty_FINAL.pdf

${ }^{64} \mathrm{Ibid}$, pages 1-2.

$65 \mathrm{Ibid}$, page 1.

${ }^{66}$ Breakingnews.ie (May 15t, 2012), "Socialist Party launch 'No' campaign on Fiscal Compact", available: http:/ / www.breakingnews.ie/ireland/socialist-party-launch-no-campaign-on-fiscalcompact-549755.html
} 
austerity already imposed on the Irish people following the recession and an EUIMF sponsored bank bailout. ${ }^{67}$

Treaty detractors were watching the Irish vote closely, as a no vote was set to inflame opposition to austerity across the continent, particularly in Greece, Italy and Spain. It was thought such a result could lead to referenda being held on the treaty in other countries. 68 Of great importance to the 'no' campaign in Ireland were the political developments in France. Anti-austerity campaigners were imploring the Irish public to believe that a rejection of the treaty could lead to its re-negotiation, and the encouraging rhetoric coming from their socialist comrades in France acted as the prime selling point for this plea. The ploy certainly worked for many austeritysceptics. One Irish voter told the Guardian on referendum day that a no vote would give Hollande "more leverage to renegotiate the treaty's terms and broker a better outcome for peripheral EU states like Ireland". She argued that it also would send "a crucial signal to Eurocrats across the continent that the Irish people are unwilling to accept the stultifying and unyielding austerity they are currently subject to" ${ }^{69}$

May the $6^{\text {th }}, 2012$ was a strong day for the European Left, hailed as the moment Greek and French voters rejected German-led austerity and the "fragile political consensus" in Europe was dealt a serious blow. ${ }^{70}$ The Greek elections had been catastrophic for PASOK and New Democracy, the country's two-largest parties, both of which were pro the EU bailouts. Benefitting from their slide were smaller parties, particularly the fiercely anti-austerity Radical Left Coalition (SYRIZA) which gained a stunning 17 per cent of the vote. ${ }^{71}$ Meanwhile, France had deposed Nicolas

\footnotetext{
67 Ibid.

68 Brady, H. (May 2012), “Ireland's fiscal treaty referendum: (More) fear and loathing in the eurozone?" Briefing note - Centre for European Reform, page 3, available: http://www.cer.org.uk/sites/default/files/publications/attachments/pdf/2012/bn_ireland_fiscal_ 11may12-5070.pdf

${ }^{69}$ Graeme Wearden (May 31 st, 2012), "Eurozone crisis live: Ireland votes on EU fiscal treaty", available: http://www.theguardian.com/business/2012/may/31/eurozone-crisis-irelandreferendum

${ }^{70}$ Noah Barkin (May 6th, 2012), "Analysis: Greek, French voters reject German-led austerity", available: http://www.reuters.com/article/2012/05/06/us-europe-electionsidUSBRE8450CY20120506

${ }_{71}$ Brady, H. (May 2012), Ireland's fiscal treaty referendum: (More) fear and loathing in the eurozone? Page 3.
} 
Sarkozy and elected Francois Hollande, the country's first Socialist President in 16 years. While the Greek vote was a considerable cause for concern for stability and consolidation in Europe, the definitive end to the Merkozy pact presented a more immediate worry for Brussels and Germany regarding the Fiscal Compact. With the agreement freshly signed in March but likely to be months away from ratification, the approach of Hollande to the treaty was seen as a key element of its success.

During a campaign centred on opposition to the austerity measures forced upon the French people by Sarkozy and Merkel, Hollande had vowed to renegotiate the Fiscal Compact should he be elected as President. ${ }^{72}$ The Socialist candidate had expressed vehement opposition to the agreement in December 2011, arguing that its consolidation-centric approach to the debt crisis would drag Europe's fragile economy back into a prolonged recession. ${ }^{73}$ A French-led effort to radically reform the Fiscal compact was exactly what Merkel, Van Rompuy and company did not need as they waited for 12 Eurozone states to push the treaty through their respective ratification processes before the new fiscal rules would officially come into play. For the first time since the onset of the crisis, Merkel as the leader of the largest and most powerful European nation did not have a strong ally in the leader of the second largest and second most powerful European nation. The potential for a serious disruption to the status quo could explain why the German Chancellor openly supported Nicholas Sarkozy during the French presidential election campaign, an extremely rare intervention from a head of state into another nation's electoral politics. ${ }^{74}$

While Social Europeans were looking to pull together an anti-austerity coalition from across the continent to unite against the Fiscal Compact, they had also found a few unlikely friends. Investment fund managers with their eyes fixed on the European bond markets were concerned after the December 2011 agreement, citing a

\footnotetext{
${ }^{72}$ Euractiv (April 4" $4^{\text {th }}$ 2012), "Hollande starts to backtrack on EU fiscal treaty", available: http://www.euractiv.com/future-eu/hollande-initiates-turn-eu-fiscal-treaty-news-511971 73 Ibid.

${ }^{74}$ Bruce Crumley (February 7th, 2012), “Why Did Merkel Endorse Sarkozy's French Presidential ReElection Bid?", available: http://world.time.com/2012/02/07/why-did-merkel-endorse-sarkozysfrench-presidential-re-election-bid/
} 
lack of foresight in the treaty, "There's no vision for what the Eurozone is going to look like in three years' time," said Mohamed El-Erian of Pacific Investment Management in an interview with the BBC. ${ }^{75}$ Paul McNamara - investment director at asset management group GAM - articulated a response to the December summit that social democrats would have been proud of, arguing that, "we need a fiscal union to accommodate a monetary union, but what we've got looks much more like an austerity union."76

An 'austerity union' was the type of reform that would turn the hand of economic agencies which had previously been so committed to prudence and stability. Standard \& Poor's denounced the EU's approach to the crisis, claiming that the agreement did not supply enough resources for the region to overcome its economic woes and argued that, "reform based on a pillar of fiscal austerity alone risks becoming self-defeating". ${ }^{77}$ Moreover, while the IMF and OECD had praised the European approach to the crisis throughout 2011, concerns began to be expressed once the full details of the pact had emerged, and as the Eurozone economy continued to stutter midway through 2012. Both organisations noted the importance of matching debt reduction with pro-growth strategies. The IMF called for much greater fiscal integration and expressed concerns for the struggling peripheral European economies, suggesting a more "supportive financial and growth-friendly environment" ${ }^{78}$ The OECD warned the prevailing approach risked causing a "vicious circle, involving high and rising sovereign indebtedness... excessive fiscal consolidation and lower growth".${ }^{79}$ These statements may not have been the rallying call for a rejection of the pact its opponents were looking for, but they certainly

\footnotetext{
${ }^{75}$ BBC (December 9th, 2011), “BBC Newsnight"

${ }^{76}$ Ibid.

77 Andrew Rettman (January 14th, 2012), “US agency drops bombshell on EU anti-crisis plan", available: http://euobserver.com/economic/114885

${ }^{78}$ IMF (July 16 th, 2012), World Economic Outlook Update, Washington D.C., USA, page 7, available: http://www.imf.org/external/pubs/ft/weo/2012/update/02/pdf/0712.pdf

${ }^{79}$ Larry Elliott (May 22nd, 2012), "Strict austerity risks derailing global economic recovery, warns OECD", available: http://www.theguardian.com/business/2012/may/22/europe-crisis-drag-onglobal-economy
} 
signalled a sentiment shifting gradually away from the existing "pre-occupation with deficits and debt" .80

\subsection{A ratified Fiscal Compact: Why the Left failed}

When Finland's ratification of the Fiscal Compact became official on the first day of 2013 , the pact gained its $12^{\text {th }}$ member and entered into European law. From the first real draft proposed by Herman Van Rompuy in early December 2011 to the signing of the intergovernmental treaty in March 2012, the Fiscal Compact had been rushed through at an atypically impressive rate for the EU. This reflected the desperation from Berlin, Paris and Brussels in the latter months of 2011 - against the backdrop of a seriously ailing economy in the region - to save the Eurozone from its almost unimaginably high indebtedness, its (rumoured) possible breakup and perhaps most importantly, the scorn of the financial markets. While the path of consolidation led by Merkel certainly provided positive benefits for her domestic popularity 81 , electoral politics came into play with the progression of the Fiscal compact in more ways than one. With French Presidential frontrunner Francois Hollande expressing his distaste for the pact in its early days, Berlin and Brussels would have sensed the best way to avoid a true political scrap over the signing of the agreement was to get it done prior to the French election, as Nicolas Sarkozy was still on hand as a prominent driver of the reform. The momentum towards the treaty's ratification was delayed only through the middle months of 2012: minor problems passing the pact through legislation in Finland and Poland, the hiccup of a referendum in Ireland and sustained protests from French socialists came months after the agreement had been signed by 25 member states, putting the Left firmly on the back foot in an effort to re-write the treaty.

There were four main factors in the European Left's failure to block the Fiscal Compact's implementation: efficiency and practicality, states' fears that rejecting the

\footnotetext{
80 McArdle, P. (2012), The Euro Crisis - The 'Fiscal Compact and Fiscal Policy', page 5, available: http://www.iiea.com/publications/the-euro-crisis-the-fiscal-compact-and-fiscal-policy 81 Wolfgang Munchau (September 23rd, 2013), "The economic consequences of Merkel mark three", available: http:// www.ft.com/intl/cms/s/0/c8fb3de8-243e-11e3-890500144feab7de.html\#axzz2hNsAy5e9
} 
pact would do more harm for them than good, the feeling that the revised rules would change very little in practice, and the numerical and institutional power behind Germany's ordoliberal orthodoxy.

\section{4.i A starting point to ease fears}

The doomsday scenarios were laid down with the December 2011 meeting labelled the "summit to save the Eurozone". 82 The need to ease global fears about the future of the EU was abundantly apparent, including to those states frustrated by German dominance over legislative change and to those states forced to impose harsh austerity policies on their people in order to receive loans from European bailout funds and stay inside the single currency.

The statement released by Eurozone leaders following the December summit made this necessity clear, asserting that "the stability and integrity of the Economic and Monetary Union and of the European Union as a whole require the swift and vigorous implementation of... moves towards a genuine 'fiscal stability union'". 83 The agreement in December was in large part an effort to convince international allies and the financial markets that the Eurozone was very much getting its act together. ${ }^{84}$

From the December agreement, there was an attempt by advocates of further fiscal tightening to allay the fears of the pact's sceptics by selling the agreement as a first step of many: a base to work from for the Eurozone. In order to achieve at least a Eurozone-wide agreement over the Fiscal compact, Berlin and Brussels had to consider somewhat of a carrot and stick approach in the negotiations. While the stick was further budgetary belt tightening, the carrot was the promise of more integration in the future, enhanced cooperation and shared responsibility. The pact

\footnotetext{
82 Sébastian Seibt (December $5^{\text {th }}, 2012$ ), "Another emergency summit to save the Eurozone", available: http://www.france24.com/en/20111204-another-emergency-summit-save-eurozone

${ }_{83}$ European Council (December 9, 2011), Statement by the Euro Area Heads of State or Government, page 2.

84 BBC (December 9th, 2011), "BBC Newsnight", available:

http://www.youtube.com/watch?v=99DfZ98sEXI
} 
was seen as a step on the road to fiscal union ${ }^{85}$, and while this may have contributed to the Eurosceptic-prone Czech Republic's decision not to sign the agreement, ${ }^{86}$ governments frustrated by the feeling of a 'German solution' to the crisis were reassured by the possibility of more fundamental structural change for the Eurozone.

Van Rompuy's draft noted the prospect of tax coordination, financial integration and perhaps even debt mutualisation. He outlined the trade-off by arguing that "longer term reforms... must be combined with immediate action [bolded in-text] to forcefully address current market tensions." 87 José Manuel Barroso summed up the expectation of continued moves towards the ever closer union stating that, "It is indeed very important that Member States agreed on a fiscal compact, but let me say that this is not enough... our citizens expect from us: a Europe of responsibility, yes but also a Europe of solidarity; a Europe of stability, yes, but also a Europe of growth and employment." 88

\section{4.ii The danger of saying no}

Perhaps the most significant reason the Fiscal compact was ratified amid the protest and proclamations of re-negotiation was the uncertainty a rejection of the pact was set to create for any state that did not join. The crucial question in the Irish referendum was whether the fear of the potential repercussions of a 'no' vote would trump the anger felt by the public at the constant wave of austerity since the crisis had begun. ${ }^{89}$ In France, Francois Hollande's fear was that alienating his country's closest and most powerful ally in the EU might do more harm than the good of standing by his word on re-negotiation and placating the angry left-wing of the French Socialist Party.

\footnotetext{
${ }^{85}$ McArdle, P. (2012), The Euro Crisis - The 'Fiscal Compact and Fiscal Policy', page 1.

${ }^{86}$ Valentina Pop (February 1st, 2012), "Fiscal treaty stirs political disputes in EU countries", available: http://euobserver.com/economic/115090

87 Van Rompuy, H. (6 December, 2011) Towards a Stronger Economic Union - Interim Report, page 4.

${ }^{88}$ European Parliament (December 13, th, 2011), "Conclusions of the European Council meeting [8-9

December], Debates - Plenary", available:

http://www.europarl.europa.eu/sides/getDoc.do?pubRef=-//EP//TEXT+CRE+20111213+ITEM$005+\mathrm{DOC}+\mathrm{XML}+\mathrm{V} 0 / / \mathrm{EN} \&$ language $=\mathrm{EN}$

${ }^{89}$ Brady, H. (May 2012), Ireland's fiscal treaty referendum: (More) fear and loathing in the eurozone? Page 4.
} 
In both cases, fear did reign over anger. For Ireland, the Fiscal Compact was almost entirely an economic animal. Frustrated by the bulk of the $€ 85$ billion bailout being directed towards the nation's failing banks, voters wanted to know whether the agreement would enforce more-of-the-same austerity or, on the other hand, whether rejecting it would lead the country back into a deep recession. The 'yes' campaigners, including both coalition parties in government and the main opposition party Fianna Fail, argued that being outside of the Fiscal compact would actually mean more austerity for Ireland as the government would be forced into borrowing further, at extraordinarily high rates, 90 and cutting expenditure in order to raise money to protect the economy against future crises. ${ }^{91}$ This would be the byproduct of the provision within the treaty excluding non-signatories from claiming funds under the ESM bailout facility. The 'no' campaigners argued that claims of a possible economic meltdown following a rejection of the pact were grossly overstated. ${ }^{92}$

The Irish voted in favour of joining the treaty as the 'yes' side had been able to convince the voters of the economic perils of being excluded. While the certainty of being disqualified from the ESM - which also influenced the decisions of other bailout recipients and peripheral states such as Portugal, Italy and Spain to join the Fiscal compact - played a role, the prospect of being cut out of the single currency altogether was certainly a factor. While a provision to remove a country from the Eurozone was not included in the treaty, many argued it would be politically untenable for a nation to stay within the single currency if they were to reject the agreement. ${ }^{93}$

Although there was a sense that the European Left were all keeping tabs on each other - from the Socialists in France to the 'no' campaign in Ireland, to the opposition in Germany and to the austerity-weary marchers in Greece, Spain and Italy - there was little doubt that the real leverage for change lay away from the high-profile

\footnotetext{
${ }^{90}$ Bruton, J. TD (March 26, 2012) The Fiscal Compact Treaty - The Choice The Irish People Have To Make

91 Ibid.

92 Breakingnews.ie (May 1', 2012), "Socialist Party launch 'No' campaign on Fiscal Compact"

93 Valentina Pop (January 17th, 2012), "Finnish Minister pours cold water on fiscal treaty"
} 
referendum in Ireland. The government in Ireland had insisted that the Eurozone would go on without them and that a 'no' vote would derail not the EU but simply the Republic itself. ${ }^{94}$ The same could not be said for France, where opponents of the agreement had more leverage than its detractors anywhere else on the Continent. Despite Francois Hollande's animosity towards the agreement however, it became clear shortly before the first round of the presidential elections in April that the Socialist candidate would take a step back and put up little fight over the core contents of the treaty. ${ }^{95}$ His tune had changed significantly since the previous December when he had vowed to oppose the pact even if it meant alienating Germany and engaging in a time-consuming legal battle. ${ }^{96}$

Hollande's compromise solution - to add pro-growth mechanisms to the existing treaty - achieved mixed success. While there was no re-write to the Fiscal compact treaty, Eurozone leaders passed a $€ 130$ billion 'growth pact' in late June 2012, inspired by the new President's plan to use mostly unspent EU funds for job creation and growth. ${ }^{97}$ However, backbench parliamentary Socialists in France refused to see the June pact as an adequate counterbalance to the Fiscal Compact and vowed to protest and vote against ratification. The Fiscal Compact was ratified comfortably in the French parliament but it was done so amid controversy and Hollande's falling popularity. ${ }^{98}$

The French President's claim of a victory in passing the treaty through parliament alongside the addition of the growth pact appeared hollow considering his initial contempt for the agreement. His fear of losing influence in Europe, as his performance in domestic poll results continued to slide, acted as the primary motivator for the U-turn towards ratification. A week after his approval rating had reached a low of 43 per cent, Hollande announced the "sweeping majority" vote for

\footnotetext{
${ }_{94}$ Bruton, J. TD (March 26, 2012) The Fiscal Compact Treaty - The Choice The Irish People Have To Make

${ }^{95}$ Euractiv (April 4 $\left.4^{\text {th }}, 2012\right)$, "Hollande starts to backtrack on EU fiscal treaty"

96 Ibid.

${ }^{97}$ Benjamin Fox (October 10th, 2012$)$, "Hollande faces down EU fiscal pact rebels", available: http://euobserver.com/political/117815

${ }_{98}$ Euractiv (October 1 $\left.1^{\text {st }}, 2012\right)$, "French protest austerity measures, EU fiscal pact", available: http://www.euractiv.com/euro-finance/french-protest-austerity-measure-news-515087
} 
ratification would "give France a bigger voice (and) enable us to forge ahead with the rebuilding of Europe that I have committed to since my election." 99

Countries that held reservations over the treaty on non-ideological grounds also fell in line due to the fear of losing influence. Poland led a small group of non-euro member states which had hoped to attend the bi-annual Eurozone summits set up as part of the agreement. The country with the largest EU population centre outside of the Eurozone was the only nation to threaten not to join the pact if excluded from the talks, with Polish Prime Minister Donald Tusk deriding a fiscal agreement which threatened to cause "the division of Europe into two clubs". ${ }^{100}$ However, the Fiscal Compact was finally passed through the Polish parliament in February 2013 after the new EU Budget had seen the country become the largest beneficiary, receiving $€ 106$ billion. ${ }^{101}$ Poland had "won the financial battle for the next seven years like no other country in Europe," claimed a satisfied Tusk. ${ }^{102}$

\section{4.iii A new treaty of few restrictions and few real changes}

Herman Van Rompuy had declared the Fiscal Compact an agreement of "more fiscal discipline; more automatic sanctions; stricter surveillance," but there were mixed feelings within the Eurozone over the true significance of the reform with many believing the new 'fiscal rule' championed by Brussels and Berlin would not radically alter nations' budgetary requirements as suggested. Austerity-weary member states signing up to the pact made two main assumptions to come to this conclusion.

The first assumption was that the term 'structural' included in the provision for limited deficits would protect them against the kind of strict scrutiny over balancing the fiscal ledger that the debt-brake rule implied at first glance. The Irish government argued that the Fiscal Compact would not, in fact, prevent countries from running budget deficits during recessions and that the 0.5 per cent limit took

\footnotetext{
99 Ibid.

100 Andrew Rettman (January 19th, 2012), "Poland renews attack on Eurozone-only summits", available: http://euobserver.com/economic/114945

101 Warsaw Business Journal (February 2nd, 2012), "Poland on course to ratify EU fiscal compact" 102 Ibid.
} 
into account the normal up and down cycles in the economy. ${ }^{103}$ This was partly a ploy by the government to refute claims made by several economists that the pact would completely rule out Keynesian counter-cyclical measures to address an economic downturn. ${ }^{104}$ However, there was validity to the government's argument as they correctly noted that a structural deficit is "an estimate of what the deficit or surplus would have been if economic conditions were normal". ${ }^{105}$

The second factor pointing towards a more lenient-than-advertised agreement was in the confusion over the precise role of the European Court of Justice in punishing states for profligate fiscal management. The treaty text states under Article 8 that if the European Committee or a "Contracting Party" (member state signatory to the pact) decide that a state has failed to comply with Article 3(2) it may bring the matter before the ECJ and the Court's judgement on proceedings will subsequently be considered binding. ${ }^{106}$ Article 3(2) says that the fiscal rule must take effect in the national law of the Contracting Parties, "at the latest one year after the entry into force of this Treaty through provisions of binding force and permanent character" ${ }^{\prime 107}$ The fact that Article 8 refers back to compliance with Article 3(2) as opposed to Article 3(1), under which point (a) states clearly "the budgetary position of the general government of a Contracting Party shall be balanced or in surplus" leaves member states struggling with fiscal deficits more than enough scope to argue that their only responsibility to the terms of the treaty itself is to pass the debt-break through national law, and not to actually adhere to it.

Commentators responding to the treaty did not miss this contentious point. The Social Europe Journal claimed the Fiscal Compact was "Much ado about nothing"108,

\footnotetext{
103 Bruton, John TD (March 26, 2012) The Fiscal Compact Treaty - The Choice The Irish People Have To Make.

104 Ibid.

105 Ibid. see: http://glossary.reuters.com/index.php?title=Structural_Deficit for a supporting definition of 'Structural Deficit'.

106 Treaty on Stability, Coordination and Governance in the Economic and Monetary Union, Article 8(1), last updated: January 22, 2013, available: http:/ / europeancouncil.europa.eu/media/639235/st00tscg26_en12.pdf, page 16.

107 Ibid, Article 3(2), page 12.

108 Sebastian Dullien (January 17th , 2012), “The 'Fiscal Compact': Much ado about nothing”, available: http://www.social-europe.eu/2012/01/the-fiscal-compact-much-ado-about-nothing/
} 
Pat McArdale of the Institute of International and European Affairs argued the agreement barely deviated from the revised SGP109 and Sebastian Dullien of the European Council on Foreign Relations maintained that it was not completely clear "whether the Fiscal Compact will be de facto more binding than the Six-pack, should national governments later decide that they do not want to follow $i^{\prime \prime} .110$ Additionally, while it was considered a coup for Merkel, Sarkozy et al. to have potential foes Spain and Italy fall in line with the concept at such an early stage, it was noted that it was unlikely either of these countries would approach a debt-break by the letter of the law. ${ }^{111}$ After all, in 2011 Italy and Spain held budget deficits of 4.5 per cent and 9.7 per cent respectively ${ }^{112}$ and they could take solace in the fact that under the limits of the SGP 23 of 27 states had been in the excessive deficit procedure, with very few of those actually punished. ${ }^{113}$ In the end, member states uncertain over the direction being advocated by the consolidation coalition could feel a reasonable sense of confidence that enforcement procedures would become tied up in either confrontation over definitions or a legal battle over the role of the ECJ.

\section{4.iv No safety in numbers}

The sturdiest nail in the coffin for the European Left's campaign against the Fiscal Compact came in the brutal reality that both power and numbers in the EU were against the movement. The 'Big Three' were reduced to a big two after the UK veto but it was Germany and France that led the way for greater fiscal discipline in the union and the implementation of this through a revised or new treaty. Of the remaining member states, all large countries had centre-right governments and only

\footnotetext{
109 McArdle, P. (2012), The Euro Crisis - The 'Fiscal Compact and Fiscal Policy'.

110 Sebastian Dullien (May 1st, 2012), "Reinventing Europe: Explaining the Fiscal Compact", available: http://ecfr.eu/content/entry/commentary_reinventing_europe_explaining_the_fiscal_compact 111 Stefan Simons and Carsten Volkery (August 18 ${ }^{\text {th }}, 2011$ ), "'Pure Symbolism': The Great Debt-Brake Swindle"

112 "Italy Government Budget", available: http://www.tradingeconomics.com/italy/governmentbudget and "Spain Government Budget", available:

http://www.tradingeconomics.com/spain/government-budget (both accessed: August 20"th 2013). 113 McArdle, P. (2012), The Euro Crisis - The 'Fiscal Compact and Fiscal Policy', page 6
} 
three - Austria, Belgium and Denmark - had Socialist ones. ${ }^{114}$ While a few noises of discontent were made in non-euro Denmark, little genuine resistance was put up by any of the three. ${ }^{115}$ This lack of material strength in the Council represented a major hurdle for Social Europeans.

In Brussels, a commitment to consolidation supported the Franco-German approach to the crisis. While the Commission often advocated a slightly more even handed approach than Merkel, Sarkozy and Van Rompuy, Barrosso was completely on board with the immediate need for a 'stability union.' Even the often awkward European Parliament - essentially powerless to block the treaty under its terms barely put up a fight against the Fiscal Compact. A motion to oppose treaty, citing its inability to "address the main elements that led to the crisis, namely the liberalisation, deregulation and over-reliance on financial markets" and admonishing the "imposition of neoliberal policies" only garnered the support of the vastly outnumbered left flank of the parliament. ${ }^{116}$ Meanwhile, the head of the ECB, Mario Draghi, stuck to an inexorably ordoliberal line throughout the Fiscal Compact's ratification process. He argued that despite severe budgets cuts deepening the recession in certain countries of the euro, the only way to maintain the integrity of the EMU was to persevere with fiscal adjustment. ${ }^{117}$

Shriti Vadera, a former Labour Minister in the UK government led by Gordon Brown, reacted to the Fiscal Compact draft by claiming the EU had "produced a toolkit with only one tool in it, which is austerity."118 The unfortunate reality for the Left was that there was just no significant force to lead the charge against such austerity and articulate this belief. With Francois Hollande's accession to the head of French politics there came hope for change: an expectation that an austerity-only

\footnotetext{
114 Valentina Pop (March 19th, 2012), "Hollande 'not alone' in bid to re-open fiscal treaty", available: http://euobserver.com/political/115625

115 Ibid.

116 European Parliament (January 16 th , 2012), "Resolution on the conclusions of the European Council meeting [8-9 December 2011] on a draft international agreement on a Fiscal Stability Union", available: http:// www.europarl.europa.eu/sides/getDoc.do?type=MOTION\&reference=B7-20120012\&language $=\mathrm{EN}$

117 Valentina Pop (April 25th, 2012), "Draghi urges Eurozone not to give up on austerity", available: http://euobserver.com/economic/116030 118 BBC (December 9th 2011$)$, "BBC Newsnight"
} 
response would was no longer a given. However, much like the IMF's admission in January 2013 that they had got it wrong on consolidation - underestimating the effect of severe budget cuts on growth and economic development ${ }^{119}$ - Hollande's challenge proved to be too little and too late to truly impact the direction of the new Fiscal compact.

\subsection{Conclusion}

The pact has been ratified by 27 of 28 European countries, with the UK remaining the only holdout. While the British veto left Berlin and Brussels frustrated in their attempts to rubber stamp the stability treaty into EU law, it has been one of the most significant developments in economic governance reform since the collapse of the global economy in 2008 and the onset of the Sovereign Debt Crisis. Just how significant it will be remains to be discovered, most likely through the courts, although signs point to a more lenient impact than what was intended. Whether or not the Fiscal Compact truly was a step on the road to fiscal union and what this union would look like were the more pertinent questions to come from the agreement.

The European Left tried, and failed, to get in the way of the Fiscal compact. Ultimately, however, calls to renegotiate the treaty were not heeded as Social Europeans struggled against the weight of institutional power behind the ordoliberal orthodoxy, while feeling pressure from Brussels to act urgently. Furthermore, there were legitimate concerns within sceptical member state governments, that a failure to sign on would result in an effective excommunication from the head table in the Council. Though some believed the treaty did little more than reinforce the status quo, this would be a telling development in itself. The Fiscal Compact was the most controversial and meaningful economic agreement since the SGP and it delivered a defeat to the European Left's vision for greater solidarity. The pact displayed the sheer strength behind the consolidation coalition during the early stages of crisis reform and the prospect of a future for Europe under an 'austerity

119 Blanchard, O. and Leigh, D. (2013), Growth Forecast Errors and Fiscal Multipliers, IMF Working Paper, page 5, available: http://www.imf.org/external/pubs/ft/wp/2013/wp1301.pdf 
union' represented a chilling concern for opponents. However, as the following chapter shows, opponents of the status quo were about to regain a sense of initiative through its approach to the Two-Pack proposals in the coming months, with a remarkably timely shift in the political climate resetting the stage for debate. 


\section{Caught in the Changing Winds: A Reprieve for Social Europe}

As the European economy dipped into a deeper crevasse and the outside world demanded leaders get their act together in the lead up to the December $8^{\text {th }}$ showdown summit, José Barroso and his Commission could at least claim they had been busy laying some groundwork for reform. With the Six-Pack about to officially enter into force, a proposed legislative add-on - the 'Two-Pack' - was tabled, two weeks prior to the 'summit to end all summits'. The proposal would not be at the forefront of the leaders' minds heading into Brussels: the need to resolve the many awkward and significant political issues involved in the Fiscal Compact negotiations meant the Two-Pack would be very much consigned to legislators respective 'deal with it later' filing systems. Months later, when the whole European political establishment did come to deal with the Two-Pack in earnest, they were to discover that tension over the proposed reform brought with it the baggage of an increasingly divided Europe.

This chapter is divided into two main sections: the first details the largely austeritybased Commission Two-Pack proposal, before examining how the May 2012 shift in the political climate led to a drawn-out and fraught negotiation process between member states and the European Parliament. The second section discusses the development of the on-going debate around Eurobonds. Here it is argued that the ability of the European Parliament and other actors to keep the issue well and truly on the table has led to a victory for the European Left, and a renewed emphasis on the need for an alternative approach to economic reform. The momentum created by Left towards the adoption of Eurobonds and the concessions gained in the final Two-Pack agreement act as two factors in a swing back towards the Social European vision from the status-quo ordoliberal dominance. 


\subsection{The Two-Pack: more of the same?}

The original proposal for the Two-Pack was set down by the Commission on November the $23^{\text {rd }}$, 2011. While the Six-Pack was designed primarily to crack-down on fiscal profligacy in the Eurozone and achieve more macro-economic convergence within the Union, the Two-Pack was mostly about oversight. The Commission stated in their release of the proposal that there was "a need for euro area Member States to go beyond the Six-Pack" and thus unveiled "two new Regulations aimed at further strengthening the surveillance mechanisms in the euro area." ${ }^{1}$ Like the Six-Pack, the add-on reform targeted Europe's misbehavers, and came during a period when the 'bailout states' were struggling mightily to get their heads anywhere close to the surface. Greece, Ireland and Portugal were all about to set new record levels of public debt - Greece's a staggering 170 per cent of GDP - and the remaining nonbailout PIIGS nations, Spain and Italy, would suffer the same dubious distinction at the conclusion of $2011 .^{2}$ Growth in the euro area as a whole had been negative in the second half of the year, leading observers to forget about the positive indicators from the same time 12 months prior to this. ${ }^{3}$

Barroso and his Commission clearly felt as though the fiscal sustainability stick had not hit the toiling periphery states hard enough, and to address this some good oldfashioned parenting was required from Brussels. The proposal introduced two separate regulatory reforms. The purpose of the first was to set "common provisions for monitoring and assessing draft budgetary plans", while also ensuring member states' correction of excessive deficits. ${ }^{4}$

The monitoring requirements included the introduction of a common budgetary timeline, whereby euro area Member States would be required to present a draft budgetary plan with independent macroeconomic forecasting for the following year

\footnotetext{
${ }^{1}$ European Commission (November,2011), MEMO/11/82, “Economic governance: Commission proposes two new Regulations to further strengthen budgetary surveillance in the euro area", Brussels, available: http://europa.eu/rapid/press-release_MEMO-11-822_en.htm 2 "Government Debt to GDP", available: http://www.tradingeconomics.com/countrylist/government-debt-to-gdp (Accessed: May 16 th 2014).

3 "Euro Area GDP Growth Rate", available: http://www.tradingeconomics.com/euro-area/gdpgrowth (Accessed: May 16 $6^{\text {th }}, 2014$ ).

${ }^{4}$ Ibid.
} 
to the Commission on October $15^{\text {th }} .5$ This was an initiative that did not radically alter the existing approach to fiscal governance in the Eurozone, especially considering the fact that co-ordination of budgetary reporting had already been set up in a similar form by the SGP and European Semester. The significant addition made by the 'monitoring and assessing' regulation was in the new power given to the Commission to require member states to revise their draft budgetary plans, should they show serious non-compliance with the SGP. 6 The proposal essentially allowed the Commission to clamp down on any attempt by a member state government to renege on their deficit and debt requirements and turn their nose up until the unruly government decided to play ball. Moreover, the draft plans would also be assessed by other euro area member states in the Eurogroup before they could become law, ${ }^{7}$ "increasing peer pressure" from other member states. ${ }^{8}$

The second of the Two-Pack's regulatory reforms was more explicitly directed at the PIIGS and other states either experiencing or threatening record levels of debt. ${ }^{9}$ Brussels' prescription for these member states was enhanced surveillance - more kindly described in the release as 'graduated monitoring'10 - the sanctioning of which would be entirely at the discretion of the Commission. The surveillance carried out with assistance from the ECB - would involve an obligation on member states to adopt measures to address sources of instability, as well as regular review missions, and the provision of more detailed financial sector data on request. ${ }^{11}$

The means by which a country would "address the source of instability" would be decided through a European Council recommended macro-economic adjustment programme. ${ }^{12}$ If, then, the Council found that a nation had not complied with the requirements set out in this programme, financial assistance being received under

\footnotetext{
${ }^{5}$ European Commission (March 14th, 2012), "Six-pack? Two-pack? Fiscal compact? A short guide to the new EU fiscal governance", available:

http://ec.europa.eu/economy_finance/articles/governance/2012-03-14_six_pack_en.htm

${ }^{6}$ European Commission (March 14th, 2012$)$, "Six-pack? Two-pack? Fiscal compact?"

7 European Commission (November, 2011), MEMO/11/82.

8 European Commission (March 14 $\left.{ }^{\text {th }}, 2012\right)$, “Six-pack? Two-pack? Fiscal compact?

9 Ibid.

${ }^{10}$ European Commission (November, 2011), MEMO/11/82.

11 European Commission (March 14th, 2012), “Six-pack? Two-pack? Fiscal compact?

12 Ibid.
} 
the EFSF (or later the ESM) could be threatened. ${ }^{13}$ While the carrot and stick approach to EU-mandated financial assistance was nothing new, the significance of the second regulation in the Two-Pack was to put Europe's trouble-making economies on constant alert and subject to the strictest scrutiny. Once it became time to debate the initiatives, both supporters and detractors of the tabled reforms agreed that they were in large part about securing greater powers for the Commission. With EU finance ministers set to discuss the proposals in February 2012, an EU diplomat argued the Two-Pack constituted "an important power of appreciation" given to the Commission, which would put countries at risk of financial implosion "in front of their responsibilities."14 MEPs sceptical about the level of Commission power emphasised the need to heavily involve the European Parliament - and member state in question - over the provision of adjustment programmes, due to concerns over a lack of "proper democratic oversight" included in the proposals. ${ }^{15}$ For its part, the Commission admitted that the surveillance process had already been "considerably improved with the Six-Pack" but argued the add-on reforms would give the Parliament's executive body "the powers needed" to more closely monitor Europe's fiscal and financial villains. ${ }^{16}$

The Two-Pack proposal put forward by Barroso and the Commission - which, unlike the Fiscal Compact, was only designed for member states in the Eurozone ostensibly appeared to be simply another chapter in the European handbook on fiscal discipline. If passed, the unprecedented powers handed to the Commission were to be used to more effectively to keep tabs on the struggling member states threatening the stability of the euro area, and to demand these countries change their ways by accepting structural reform. As such, the prevailing flavour of economic governance reform in the EU looked unlikely to be compromised by the proposals.

\footnotetext{
${ }^{13}$ European Commission (March 14th, 2012), “Six-pack? Two-pack? Fiscal compact?

14 "Ministers debate new EU powers over national budgets", available:

http://www.euractiv.com/euro-finance/ministers-debate-new-eu-powers-n-news-511005 (Accessed: May 26th, 2014).

${ }^{15}$ Green economic affairs spokesperson Phillippe Lamberts (Belgium), source: EurActiv (June 14th, 2012), "MEPs give green light to negotiate new fiscal discipline package", available: http:// www.euractiv.com/euro-finance/meps-give-green-light-negotiate-news-513286

${ }^{16}$ European Commission (November, 2011), MEMO/11/82.
} 
Critics of Europe's 'Austerity union', cemented by the Fiscal Compact agreement, would not have felt appeased in the slightest by the core elements of the latest effort with Germany's influence felt once more. However, the Commission's decision to accompany the proposals with a 'Green Paper on the feasibility of introducing Stability Bonds' was to change the nature of the discussion altogether.

Two months prior to the Two-Pack proposals, President Barroso announced that the Commission was to study and present possible options for a Eurobonds scheme. ${ }^{17}$ In an address in front of the European Parliament in the wake of further economic turmoil in Europe, Barroso had made it abundantly clear that deeper integration of euro area economic and budgetary policies was a vital part of the solution. In a clear break from his earlier consolidation-laden tone, he reiterated this belief two weeks later in his State of the Union Address by maintaining that "once the euro area is fully equipped with the instruments necessary to ensure both integration and discipline, the issuance of joint debt will be seen as a natural and advantageous step for all."18

The Commission presented three options for the adoption of "Stability Bonds" alongside the Two-Pack proposals on November $23^{\text {rd }}$. These varied based on different degrees of "substitution of national issuance" - in other words, the extent to which bonds would be delivered via a European body as opposed to by individual member states' governments - and on "the nature of the underlying guarantee" (which and how many member states would be liable for funding this debt). ${ }^{19}$ The options ranged from ambitious to conservative and reflected an acknowledgement within the European community that Eurobonds were very much a risk versus reward prospect. While Option 1 - the most all-encompassing and ambitious approach - was to have "very strong potential effects on stability and

\footnotetext{
${ }^{17}$ José Manuel Barroso (September 14 ${ }^{\text {th }}$, 2011), “Speech by President Barroso to the European Parliament during the debate on the economic crises and the euro", available: http://europa.eu/rapid/press-release_SPEECH-11-572_en.htm 18 José Manuel Barroso (September 28th, 2011), "European renewal - State of the Union Address 2011", available: http://europa.eu/rapid/press-release_SPEECH-11-607_en.htm ${ }^{19}$ European Commission (November 23rd, 2011), MEMO/11/820, “European Commission Green Paper on the feasibility of introducing Stability Bonds", Brussels, available: http://europa.eu/rapid/press-release_MEMO-11-820_en.htm
} 
integration" yet "pose a relatively high risk of moral hazard", Options 2 and 3 were set up to reduce moral hazard, either by limiting the substitution of issuance or lessening liability for the member states, thereby also reducing the positive effects on overall financial stability and integration.

The Green paper also commented on concerns around the potential for change to the EU treaties, in the case of the adoption of "Stability Bonds". The Commission noted that bonds issued "with joint liability and several guarantees would be incompatible with the current 'no bailout' provision". ${ }^{20}$ This would have been the case for both the ambitious and moderate options, leaving the "relatively rapidly deployable"21 conservative option as the easiest, but most incomplete, way forward. While the Green Paper also presented a list of pros and cons for the implementation of mutualised debt and provided a level of clarity for policymakers on the levels of risks and benefits involved in each of the options presented, the Commission decided against making any clear recommendation as to the way forward. Instead it decided to launch "a broad consultation" on the issue, stating that all "possible advantages, challenges, options and operational terms require careful consideration." 22

There was undoubtedly merit in the Commission's decision not to hedge its bets without the involvement of the member states and the European parliament but the move represented a back-down from Barroso's lofty rhetoric only several weeks beforehand. In his State of the Union Address, the President had emphasised the need for immediate action: "we can do a lot within the existing Treaty of Lisbon" he said, "and there is no excuse for not doing it, and for not doing it now". ${ }^{23}$ Furthermore, the decision to label the options by the compromise term "Stability Bonds", rather than Eurobonds, sent a clear message to observers that the Commission had somewhat buckled under institutional pressure in Brussels, or had at least experienced cold feet. Explicitly or otherwise, Barroso appeared to have felt

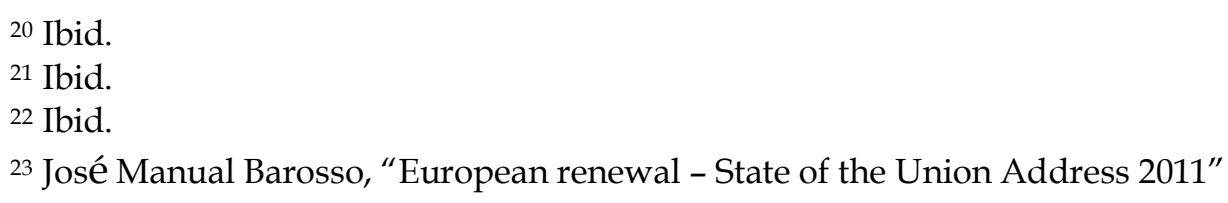


the stern disapproving gaze from Berlin. Nevertheless, the Commission's Green Paper had helped to create a renewed momentum for a debate on Eurobonds, particularly as it wasn't the only proposal of its kind to be released to the world at the conclusion of 2011. Days prior to the presentation of the Green Paper, the German Council of Economic Experts (GCEE) proposed a new twist on Eurobonds, named the European Redemption Pact, in its annual report. ${ }^{24}$ The GCEE - an academic body made up of five members designed to advise German policymakers on issues of economic policy ${ }^{25}$ - created "a novel solution to the crisis" by outlining a plan for the partial and temporary pooling of European debt.

The economic advisors in the GCEE sought to emphasise the differentiation between their proposal and a fully-fledged plan for Eurobonds by positioning their initiative as an intermediate option between greater fiscal discipline and the expansion of a transfer union. Its aim, were the proposal be put in place, would be to "ease down the current unsustainable levels (of debt) while implementing credible fiscal reform policies in all Eurozone nations."26 It would do this by using a "common consolidation pact and binding national debt caps" in order to bring national debt levels below the 60 per cent of GDP limit prescribed by the SGP, while also giving the participating states "the opportunity to finance themselves to a limited extent via a fund for which all are jointly liable." 27 This 'limited extent' referred to the provision that member states would only be able to refinance via the funding mechanism below the level of a 60 per cent national debt-to-GDP ratio. In other words, governments would have to ensure that the debt they had amassed on their own stayed strictly at or below the 'brake'.

\footnotetext{
${ }^{24}$ German Council of Economic Experts (18 ${ }^{\text {th }}$ November, 2011), "Third Chapter: Euro Area in Crisis" in Assume Responsibility for Europe: Annual Economic Report 2011/12, Economic Development Federal Statistics Office, Wiesbaden, available: http://www.sachverstaendigenratwirtschaft.de/schuldentilgungspakt.html?L=1

${ }^{25}$ Objectives and tasks - German Council of Economic Experts, available: http://www.sachverstaendigenrat-wirtschaft.de/ziele.html?\&L=1 (Accessed: May 26 th, 2014). ${ }^{26}$ German Council of Economic Experts (November 9th, 2011), "A European Redemption Pact", in Vox-EU online, available: http://www.sachverstaendigenratwirtschaft.de/fileadmin/dateiablage/Pressemitteilungen/A_european_redemption_pact.pdf ${ }^{27}$ GCEE (18 $8^{\text {th }}$ November, 2011), "Third Chapter: Euro Area in Crisis"
} 
While the GCEE stated that the strings attached to the pact - including an approximate time limit for the scheme of 25 years - equated to a "decisive difference from the idea of Eurobonds", the advisors were fully aware that a plan to save the Eurozone from imploding would not work without a convincing demonstration that solidarity would prevail. ${ }^{28}$ This could only be done "through strong countries lending their reputation... to member countries facing a liquidity crisis." The experts' plan to pool joint liability in the trillions of Euros was undoubtedly "a grand scheme (requiring) bold action and a long term commitment to the Eurozone." 29

\section{1.i The European Parliament's power-play}

The Commission's proposed regulations on enhanced surveillance and budgetary oversight had little trouble getting by European finance ministers in February 2012. The Council set out its common position for negotiation with the Parliament on February $21^{\text {st }}, 30$ with its amendments making no noteworthy changes to Barroso's proposals. ${ }^{31}$ Passing the Two-Pack through the European Parliament turned out to be an entirely different story.

The Two-Pack first came before MEPs in the Economic and Monetary Affairs Committee in mid-May 2012, almost six-months after the Commission had made its proposals. While this break in the process was not particularly out of the ordinary, it was a delay that the European Left seized upon with glee. The European Parliament's left-wing could see three important developments in their favour as they prepared to negotiate the terms of the agreement: the renewed discussion over Eurobonds brought about by the Commission and the GCEE reports, the failure of austerity focused response to the crisis to turn around the European economy, and

\footnotetext{
${ }^{28}$ GCEE (November 9th, 2011), “A European Redemption Pact"

29 Ibid.

${ }^{30}$ Council of the European Union (February 21st, 2012), "Council agrees on second economic governance package", Press release 6624/12, Brussels, available: http://www.consilium.europa.eu/uedocs/cms_data/docs/pressdata/en/ecofin/128085.pdf ${ }_{31}$ De la Parra, S. (2013) The two-pack on economic governance: an initial analysis, European Trade Union Institute, available: http://www.etui.org/Publications2/Background-analysis/The-two-pack-oneconomic-governance-an-initial-analysis
} 
most significantly, a shift in the political climate, brought about by socialist triumphs in the French and Greek elections. ${ }^{32}$

While it was difficult to criticise the lack of progress made under economic governance reforms to date - only the Six-Pack had come into force at this point Social Europeans could point to a broader failure in the austerity-dominated response to the crisis, whether enforced through bailout conditions or within the members states themselves. By May 2012, Euro area unemployment had ticked above 11 per cent ${ }^{33}$ - a record high - and Europe's periphery economies were mostly contracting 34 , fuelling fears that under the existing approach, any sort of meaningful recovery would be years away. At the same time, the Eurobonds Green Paper released by the Commission alongside the Two-pack proposals gave the Left a blueprint-of-sorts for an alternative approach, or at least options to re-ignite the debate over a more collective attitude towards reform. Of more significance was the GCEE's report. The fact that these five academics tasked with advising Europe's biggest roadblock to the mutualisation of debt - the German government - had declared the importance of collective responsibility with such vigour, meant that European socialists had an unlikely ally and a stronger base from which to debate.

Despite these meaningful developments, it was more the results of the recent French and Greek national elections which had given the European Left momentum and presented the socialist-led parliamentary faction in Brussels with an opportunity to change the debate. Both the upsurge in support for the leftist coalition SYRIZA in Greece and victory for Socialist Francois Hollande in France had been inspired by fierce campaigns against domestic and European-wide austerity (see Chapter 2), and like-minded MEPs were more than ready to exploit this.

The left-wing political groups in the Parliament, namely the Socialists and Democrats (S\&D), Greens-European Free Alliance (Greens-EFA) and the European

\footnotetext{
32 Ibid.

33 "Euro Area Unemployment Rate", available: http://www.tradingeconomics.com/euroarea/unemployment-rate, (Accessed: 31 $1^{\text {st }}$ May, 2014). 34 "GDP Growth Rate", available: http:/ / www.tradingeconomics.com/country-list/gdp-growth-rate, (Accessed: 31 $1^{\text {st }}$ May, 2014).
} 
United Left-Nordic Green Left (EUL/NGL), saw the Commission's proposals as "focusing only on the austerity and discipline side". ${ }^{35}$ Claiming that "the world was a different place when the Commission made its proposals" 36 , the Socialists asked for the vote in the Economic and Monetary Affairs Committee to be postponed, on the very day it was due to take place. ${ }^{37}$ The opportunistic move was made only a week after the polls had closed in France and Greece, as the European Parliament's largest left-wing group insisted that changes in the EU's political landscape required the radical revision of certain Two-Pack provisions. ${ }^{38}$. Conversely, the leader of the European Peoples' Party (EPP) and centre-right faction within the Committee, JeanPaul Gauzès, demanded that the vote on the Parliament's amended Two-Pack proposals go ahead as scheduled. Gauzès cited the need for the legislation to enter into force as quickly as possible while brushing off the Left's delaying tactics. "Changes in the political environment happen all the time", he said 39 Ultimately, the S\&D group could not gain enough support in their bold attempt to capitalise on the change in the political winds and it was decided by a very narrow margin that the vote should go ahead on May $14^{\text {th }} .40$

Despite their failure to block the vote, the Socialists received more support in their opposition to the overall nature of the Commission's Two-Pack proposals. The Parliament's third largest political group - the centrist Alliance of Liberals and Democrats for Europe (ALDE) - crucially backed up the S\&D MEPs in their criticisms of an 'austerity-only' approach. ${ }^{41}$ In the lead-up to the drafting of

\footnotetext{
35 De la Parra, S. (2013) The two-pack on economic governance: an initial analysis.

${ }^{36}$ European Parliament (May 15th, 2012), “Fiscal Policy: Growth dimension and control of new Commission powers needed", press release, available:

http://www.europarl.europa.eu/committees/en/econ/press-releases.html?action=10

37 De la Parra, S. (2013) The two-pack on economic governance: an initial analysis.

38 Ibid.

${ }^{39}$ European Parliament (May 15th, 2012), “Fiscal Policy: Growth dimension and control of new Commission powers needed"

4021 MEPs in the Committee decided in favour of the vote being held as scheduled, with 19 voting against and 3 abstaining.

Source: European Parliament (June 7th, 2012) “Economic governance "two pack" - Q\&A", available: http://www.europarl.europa.eu/news/en/newsroom/content/20120607BKG46436/html/Economic-governance-two-pack-QA

${ }^{41}$ European Parliament (March 7th, 2013), "Economic governance "two-pack" background note", available: http://www.europarl.europa.eu/news/en/newsroom/content/20130304BKG62046/html/Economic-governance-two-pack-background-note
} 
amended proposals, a rift between the left-bloc (including ALDE) and the right-bloc in Brussels compromised the passage of the Pact. The main issue was whether the legislation should be restricted only to fiscal rules preventing excessive deficits and enforcing reforms in 'programme countries' or whether it should include mechanisms for solidarity and further economic integration in the Eurozone. ${ }^{42}$ The configuration of coalitions between the parliamentary groups provided no clear majority on the matter either way, which initially made the impasse all the more difficult.

In spite of the Socialists' risky late-in-the-game tactics, amended texts for both of the Commission's proposed regulations were passed by the Committee. ${ }^{43}$ A number of alterations were asked for by the two opposing Committee Rapporteurs in Gauzès and S\&D MEP Elisa Ferreira and, unsurprisingly, it was Ferreira's amended draft on "common provisions for monitoring and assessing draft budgetary plans" which demanded more. ${ }^{44}$

The Socialists' response had inserted a number of amendments under three themes. First of all, the text sought to place limits on the Commission's power by emphasising a transparent and democratic budgetary oversight process through which other parties would be able to engage. Secondly, considerable protections for growth, key sectors such as health and education, and national institutions like wage formation practices were set down to prevent Commission and Council-mandated cuts having a negative effect. Finally, and most significantly, Ferreira's draft ambitiously asked for the creation of a European Redemption Fund, a roadmap for the introduction of Eurobonds and a proposal for a European growth facility from the Commission (see Table One for more detail). ${ }^{45}$ The Portuguese MEP argued for

\footnotetext{
42 Ibid.

${ }^{43}$ European Parliament (June 7th, 2012) "Economic governance "two pack" - Q\&A"

${ }^{44}$ A rapporteur is an MEP elected by his or her colleagues within a parliamentary committee to draft a report based on a particular Commission proposal or other document, and subsequently report back to the committee or plenary regarding the findings/arguments of the report.

For a further explanation of this role see: European Parliament (July 27th, 2006), "A 'rapporteur' - the person who presents reports to Parliament", available:

http://www.europarl.europa.eu/sides/getDoc.do?type=IMPRESS\&reference $=20060725$ STO09938\&language $=\mathrm{EN}$

${ }^{45}$ European Parliament (June 7th, 2012) “Economic governance "two pack" - Q\&A"
} 
the amendments on the basis that there was "no evidence showing the effectiveness of rules-based fiscal frameworks in supporting sound and sustainable fiscal policies", and that the current consolidation-based approach to economic governance by itself would "only lead to a prolonged recession within the Euro area." 46

On the other hand, the amended text put forward by Jean-Paul Gauzès for the regulation on member states in severe financial difficulties largely maintained the spirit of the Commission's proposal. ${ }^{47}$ This was expected in a sense, as Gauzès' EPP (the largest group in Parliament) and the British Tory Party-dominated European Conservatives and Reformists (ECR) had been outspoken in their support for the austerity-heavy response to the crisis. In fact the centre-right's proposals actually sought to further increase the Commission's powers by implementing a reversed qualified majority voting (RQMV) rule for the Council. Thus when the Commission was to recommend correction measures or require debt reduction plans for member states, their decisions would be considered adopted unless they were explicitly opposed by a majority of the Council. ${ }^{48}$

Due to the very difficult passage of the amended Two-Pack proposals through the Economic and Monetary Affairs Committee, MEPs decided that in order to gauge the level of support in the house, the texts would be put to a vote in the Plenary. While this action was not constitutionally necessary, there was a clear strategy on the part of European politicians to boost support and provide Parliament with a strong mandate going into negotiations with the Council..$^{49}$ On the $13^{\text {th }}$ of June, Parliament approved both texts by overwhelming majorities: Gauzès resolution received 471 votes for, 97 against, with 78 abstentions while Ferreira's text gained 501 affirmative votes, with 138 against and 3 abstentions. ${ }^{50}$ MEPs - particularly on the left - were

\footnotetext{
${ }^{46}$ European Parliament - Committee on Economic and Monetary Affairs (March 13"th, 2012),

"Amendments 47-287, Draft report Elisa Ferreira", available:

http://www.europarl.europa.eu/meetdocs/2009_2014/documents/econ/am/895/895611/895611en . $\mathrm{pdf}$

${ }_{47}$ European Parliament (June 7th, 2012) “Economic governance "two pack" - Q\&A"

48 Ibid.

${ }^{49}$ De la Parra, S. (2013) The two-pack on economic governance: an initial analysis.

${ }^{50}$ EurActiv (June 14 $\left.{ }^{\text {th }}, 2012\right)$, “MEPs give green light to negotiate new fiscal discipline package”
} 
full of praise for their achievement. ALDE Group President Guy Verhofstadt said the proposal represented "the first time... a structural solution (is) on the table" 51 while the Greens claimed the result to be a "milestone"52 that set out "a clear and constructive alternative to the failed one-sided austerity, which has characterised the response to the economic crisis so far." 53 Socialist leader Hannes Swoboda went as far to suggest the proposals put forward were "the core of a fiscal union". ${ }^{4}$ MEPs in the EPP believed the Two-Pack provided the EU with the necessary tools to further scrutinise fiscal behaviour in the member states, but, like their centre-left counterparts, they also praised the agreement for its level of compromise. Clearly feeling as though the proposals included strong elements to allow the Commission and Council to keep profligate states in check, the EPP stressed that it would fully support the principle of a redemption fund, should it be backed up by analysis from the Commission. ${ }^{55} \mathrm{As}$ delegates prepared for negotiations with the Council, there was a feeling that the impressive result in the plenary had sent a strong signal of togetherness in the Parliament.

\section{1.ii Passing the pact: battle lines drawn}

There had been a degree of bullishness from MEPs over the chances of agreeing the bulk of their Two-Pack proposals with the Council. This was helped by a belief on the Left that some of the bigger, more powerful member states were altering their positions in regard to the original Commission proposal and the general direction of economic governance reform. ${ }^{56}$ Hannes Swoboda confidently asserted that the Council had been "shifting its position on how much austerity is needed." 57 There was an acceptance among those on both sides in the Parliament, and from outside

\footnotetext{
${ }^{51}$ EUobserver (June 13'th 2012), "MEPs agree proposal towards 'fiscal union'”, available: http://euobserver.com/economic/116608.

52 Ibid.

${ }^{53}$ EurActiv (June 14 $4^{\text {th }}, 2012$ ), "MEPs give green light to negotiate new fiscal discipline package"

${ }^{54}$ EUobserver (June 13 $\left.3^{\text {th }}, 2012\right)$, "MEPs agree proposal towards 'fiscal union'”

${ }^{55}$ European Parliament (May 15th, 2012), “Fiscal Policy: Growth dimension and control of new Commission powers needed"

${ }^{56}$ S\&P group leader Hannes Swoboda claimed his own country Austria was one of the member states wavering over the austerity-first approach to the crisis. Source: EurActiv (June 14th 2012), "MEPs give green light to negotiate new fiscal discipline package"

${ }^{57}$ European Parliament (May 15th, 2012), “Fiscal Policy: Growth dimension and control of new Commission powers needed"
} 
observers, that much would depend on the wider political context when it came to negotiations with the member states. ${ }^{58}$

Passing the Two-Pack into law turned out to be far from plain sailing for Europe's political players. When an agreement was finally reached nine months after the plenary vote, Parliament had failed to force through any major changes to Brussels ordoliberal approach (see Table One). The text largely reflected Europe's existing line of attack: more scrutiny over national budgets and stricter fiscal rules for misbehaving members, with a twist in the greater level of power and influence given to the Commission. Moreover, none of the European Parliament's truly controversial proposals had been accepted as member states successfully fought to avoid the inclusion of a European Redemption Fund, an expensive 'growth facility' and a promise to introduce Eurobonds. However, while the European Left could be forgiven for feeling unsatisfied with the final result, the process had highlighted the extent to which the nature of European economic reform negotiations were changing, against the backdrop of a more austerity-sceptical EU.

The European Parliament negotiators had gone into discussions with EU finance ministers knowing their proposals for greater economic solidarity - and particularly for joint debt liability - were set to cause a stir. This was quickly confirmed by the reaction of some member states to Parliament's draft texts. It became immediately apparent that the Council would largely stick to the position it had formed months earlier in February, as Germany and its allies in the Council remained unimpressed by the idea of introducing any sort of Euro area debt redemption scheme. ${ }^{59}$ Furthermore, many held reservations over the use of the Two-Pack to promote growth and investment, rather than simply shore up fiscal rules and oversight mechanisms in the Eurozone. ${ }^{60}$ With MEPs holding their corner, negotiations throughout 2012 proved to be mostly fruitless. Only 10 days after the Presidency of the Council had informed ministers that it was very close to reaching an agreement

\footnotetext{
58 EUobserver (June 13 ${ }^{\text {th }}, 2012$ ), "MEPs agree proposal towards 'fiscal union'”

59 European Parliament (March 7th, 2013), "Economic governance "two-pack" background note" 60 Ibid.
} 
on the Two-Pack ${ }^{61}$, talks were suspended in mid-December, primarily at the insistence of Socialist, Green and Liberal MEPs who continued to demand provisions for a redemption fund to balance out the austerity-centric regulations agreed to by the Council, which they believed simply served to reinforce the status quo. ${ }^{62}$ After talks had resumed in early 2013, MEPs expressed their frustration by what some believed to be member state arrogance in the negotiation process. Sven Griegold, of the Greens, said the hold-up was due to the Council's belief that it could simply show up with its decision and force Parliament into submission. ${ }^{63}$ However, Parliament continued to demand concessions.

When a deal was agreed in February, despite remaining true to the spirit of the Commission's original proposals, the legislation did include a number of noteworthy concessions offered to Parliament and the European Left. MEPs had managed to temper the advancement of austerity-focused national budgetary surveillance by ensuring that Commission-mandated reform for struggling economies would not hurt national healthcare and education, and that national institutions such as wage practices would be protected. Furthermore, deficit reduction timetables would be applied with more flexibility in exceptional circumstances thanks to the Parliament's efforts in negotiations (see Table One). ${ }^{64}$ The most significant of the concessions for the future of Europe however, was the commitment by the Commission to study the "feasibility" of introducing Eurobonds and a debt redemption fund and report back to the Parliament on its findings by

\footnotetext{
${ }^{61}$ Cyprus Presidency of the European Union (December 4th 2012), “Press release - 'Two-Pack' and Single Supervisory Mechanism closer to a final agreement", available:

http:// www.cy2012.eu/index.php/en/news/press-release-two-pack-and-single-supervisorymechanism-closer-to-a-final-agreement

62 De la Parra, S. (2013) The two-pack on economic governance: an initial analysis

${ }^{63}$ Ian Wishart (January 30th 2013 ), “MEPs and member states clash over financial rules - concern over Council's approach to negotiations", available: http://www.europeanvoice.com/article/meps-andmember-states-clash-over-financial-rules/

${ }^{64}$ As indicated in Table One, one of the two main Parliament proposals under the regulation regarding enhanced surveillance for member states in serious financial difficulty - Reversed qualified majority voting in the Council on national budgetary reform - was approved in the process and became part of the Two-Pack legislation. The other major amendment in the Gauzès text - bankruptcy protection for member states facing default - was not approved amidst fears it would cause alarm in financial markets.

Source: EUobserver (June 13" th 2012), "MEPs agree proposal towards 'fiscal union'".
} 
early $2014 .{ }^{65}$ While this was derided by some observers as a back-down from MEPs ${ }^{66}$ and merely appeared to kick the proverbial can down the road, it would serve to keep the issue of Eurobonds on the debating table, and slowly but surely up the pressure on Brussels to find a legitimate alternative to the consolidation's existing approach to European economic reform.

The amendments successfully inserted into the text by Parliament showed MEPs had been able to exert a far-greater level of influence over the Two-Pack legislation than in any of the previous economic governance reforms combined. They had been aware of their superior position of strength prior to the talks. Following the landslide plenary vote in June 2012, a Parliament official expressed his belief that debt mutualisation could legitimately be on the table for the first time: "before Hollande's vote, I would have said the redemption fund was just a negotiating chip they would let drop. But now the political winds have changed." 67 Despite this, there was no redemption fund, nor a 100 billion growth provision carved into the final Two-Pack text, both of which had been so vociferously fought for by the Left. The noninclusion of the most controversial proposals set down by Parliament could be put down to three main factors: the need for efficient reform, material power in the Council and a less accommodating than expected political climate at the time.

With the Six-Pack and the Fiscal Compact already agreed prior to the adoption of this particular piece of legislation, efficiency was seen in this case by some as a secondary concern: an attitude which undoubtedly contributed to the lengthy delay in producing an agreement on the Two-Pack. Despite this, with the Eurozone economy still failing to gain ground during the summer and spring of 2012, the call for further action from member state governments and the international community unsurprisingly led to a feeling of urgency in Brussels. In October - with

\footnotetext{
${ }^{65}$ European Parliament (January 16 $\left.{ }^{\text {th }}, 2013\right)$, “Texts adopted - feasibility of introducing Eurobonds", available: http:// www.europarl.europa.eu/sides/getDoc.do?pubRef=-//EP//TEXT+TA+P7-TA2013-0018+0+DOC+XML+V0//EN

${ }_{66}$ De la Parra, S. (2013) The two-pack on economic governance: an initial analysis

${ }^{67}$ EUobserver (June 13 $3^{\text {th }}, 2012$ ), "MEPs agree proposal towards 'fiscal union'”
} 
unemployment at a record $11.6 \%$ high and rising 68 - the European Council demanded legislators find an agreement before the end of the year.

The problem for the European Left, led by Elisa Ferreira and the Socialists insisting upon more economic solidarity, was that urgency of any sort over the Two-pack seriously compromised the likelihood of their success. It had been well understood on both sides of the political fence for some time that the introduction of a joint debt liability scheme would never be an overnight phenomenon in Europe. Thus it followed: should a genuine proposal be put on the table, the terms involved in adopting such a long-term solution would require stringent and detailed debate. While the main aspects of the Two-Pack set down by the Commission were consistent with the existing reforms to economic governance, the creation of a redemption fund would represent a considerable break from this pattern and the Left needed as much time as it could get to rally support for such a fundamental shift.

Both the redemption fund proposal put forward by the GCEE and the Commission's Green Paper on Eurobonds noted that these options were unlikely to be set in stone in the short-term. Crucially, during tripartite negotiations with Parliament and the member states, the Commission said it would not be able to put a legitimate proposal for Eurobonds in place by the end of 2013. ${ }^{69}$ This was a curious admission by the Commission, especially since they had produced their Green Paper on the issue around a year prior to the impasse in negotiations. Perhaps the greater 'efficiency concern' for the Left was in another idea highlighted by the Green Paper: that the introduction of a comprehensive debt mutualisation scheme would very likely have to involve treaty change at the EU level. Most parties were, again, in agreement over this inconvenient fact. As was the case with the Fiscal Compact (see Chapter 2), the need to make changes to the EU treaties was bound to scare off some and not concern others. However such a move would necessarily involve significant

\footnotetext{
68 Julia Kollewe and Phillip Inman (October 31'st, 2012), "Eurozone unemployment hits new high", available: http://www.theguardian.com/business/2012/oct/31/eurozone-unemployment-recordhigh-eurostat

${ }^{69}$ European Parliament (March 7th, 2013), "Economic governance "two-pack" background note"
} 
political wrangling and add a - mostly unwanted - extra layer alongside further delays to the debate.

While José Manuel Barroso and his Economic Affairs Commissioner Oli Rehn may have felt unable to produce a passable proposal for a mutual debt issuance scheme within the timeframe for agreeing the Two-Pack, much of their decision not to push for its inclusion was down to insufficient support for Eurobonds in the powerful Council. ${ }^{70}$ The Commission quite simply did not want to lose face at this stage when they knew there was a strong antagonism towards the issue in some of the member states. This was most especially the case for Germany, which led a group of countries fervently opposed to any form of mutualised debt. ${ }^{71}$ The same could be said of the Socialists attempts to have a $€ 100$ billion 'growth fund' inserted into the Two-Pack agreement. The priorities of centre-right finance ministers in Northern Europe were still centred around tightening the fiscal straightjacket on misbehaving members. It was clear that the shift in the political climate was more ably exploited in the European Parliament than in the Council: the massive majority of the plenary voting for a more fundamental shift in economic governance reform could not translate to a group where a qualified majority is needed and decisions of such importance are rarely ever taken if not through unanimity. ${ }^{72}$

Finally, over the latter months of 2012, the political climate had become somewhat less advantageous for the bold reform asked for by the Left. Francois Hollande had made big waves at his first European Summit in late May, following his momentous election win two weeks earlier. ${ }^{73}$

\footnotetext{
${ }^{70}$ De la Parra, S. (2013) The two-pack on economic governance: an initial analysis.

${ }^{71}$ Germany's opposition to Eurobonds, and the dwindling coalition against debt mutualisation, will be examined in detail in the following section.

Source: Benjamin Fox (12 ${ }^{\text {th }}$ February, 2013), "Deal near on Eurozone economic governance laws, says Rehn", available: http://euobserver.com/news/119023

72 "The Union's decision making procedures - Extension of qualified majority voting" (accessed: June 9th, 2013), available: http://europa.eu/scadplus/constitution/majority_en.htm

${ }^{73}$ Carsten Volkery (May 24 $\left.4^{\text {th }}, 2012\right)$, "France Dominates EU Summit: Hollande Steals the Show from Merkel", available: http://www.spiegel.de/international/europe/euro-bond-discussion-dominateseuropean-union-summit-a-834865.html
} 


\begin{tabular}{|c|c|}
\hline \multicolumn{2}{|c|}{ Table One: The Two-Pack - what made it in } \\
\hline Parliament's draft ${ }^{74}$ & Final version ${ }^{75}$ \\
\hline \multicolumn{2}{|c|}{$\begin{array}{c}\text { Proposals from Elisa Ferreira - S\&P76 } \\
\text { Common provisions for monitoring and assessing draft budgetary plans }\end{array}$} \\
\hline $\begin{array}{l}\text { Limit Commission power through 'delegated } \\
\text { acts' }\end{array}$ & Rejected \\
\hline $\begin{array}{l}\text { Protect national practices and institutions } \\
\text { such as wage formation }\end{array}$ & $\begin{array}{l}\text { Approved - "the need to respect national } \\
\text { practices and institutions" (Art. 1, Para 3) }\end{array}$ \\
\hline More veto checks for MEP on Commission & Rejected \\
\hline $\begin{array}{l}\text { Opportunities for parties to engage in } \\
\text { economic dialogues on points of contention }\end{array}$ & $\begin{array}{c}\text { Approved - provides scope for discussion } \\
\text { between Council, Commission, Parliament, } \\
\text { IMF, ECB and member states over enhanced } \\
\text { surveillance (Art. 3) }\end{array}$ \\
\hline $\begin{array}{l}\text { Encourage the involvement of national social } \\
\text { partners and civil society organisations }\end{array}$ & $\begin{array}{l}\text { Partially Approved - "Recognising the role of } \\
\text { social partners at EU level" (Articles } 1 \text { and } 6 \text { ) }\end{array}$ \\
\hline $\begin{array}{l}\text { Commission's expanded powers should not } \\
\text { be used to hinder economic growth }\end{array}$ & $\begin{array}{c}\text { Partially approved - “Economic partnership } \\
\text { programmes must identify priorities for } \\
\text { enhancing competitiveness and long-term } \\
\text { growth" (Art. 7) }\end{array}$ \\
\hline $\begin{array}{c}\text { Requested significant cuts for 'programme } \\
\text { countries' should not hurt education and } \\
\text { healthcare }\end{array}$ & $\begin{array}{l}\text { Approved - "Taking account of the financial } \\
\text { requirements to continue undertaking } \\
\text { 'fundamental policies', such as education and } \\
\text { healthcare" (Art. 6, Para 5) }\end{array}$ \\
\hline $\begin{array}{l}\text { Deficit reduction timetables applied more } \\
\text { flexibly in exceptional circumstances }\end{array}$ & Approved \\
\hline Creation of a European Redemption Fund & Rejected \\
\hline Introduction of Eurobonds & $\begin{array}{l}\text { Rejected - Commission to study "feasibility } \\
\text { of introducing Eurobills" and debt } \\
\text { redemption fund. }\end{array}$ \\
\hline $\begin{array}{l}\text { Creation of a } € 100 \text { billion European Growth } \\
\text { facility }\end{array}$ & Rejected \\
\hline \multicolumn{2}{|c|}{$\begin{array}{c}\text { Proposals from Jean-Paul Gauzès - EPP } \\
\text { Provisions for enhanced surveillance on member states in severe financial difficulty }\end{array}$} \\
\hline $\begin{array}{l}\text { Mechanism to allow for a national default } \\
\text { and US Chapter 11-style bankruptcy } \\
\text { protection }\end{array}$ & Rejected \\
\hline $\begin{array}{c}\text { Increased Commission powers by } \\
\text { introducing Reversed Qualified Majority } \\
\text { Voting for the Council on debt reduction } \\
\text { plans }\end{array}$ & Approved \\
\hline
\end{tabular}

${ }^{74}$ European Parliament (June 7th , 2012) "Economic governance "two pack" - Q\&A"

${ }^{75}$ European Parliament (March 7th, 2013), "Economic governance "two-pack" background note"

76 While the amendments made by Parliament to the original Commission proposal totalled more than the proposals included in Table One, many can be included under one umbrella. For example, there were several amendments built-in to the Ferreira text that focussed on further opportunities for parties to engage in economic dialogue in regard to Commission decisions and points of contention. 
However, the French President's standing in Europe appeared to be on a slow but steady decline throughout the remainder of the year as he pulled back from initial plans to re-negotiate the Fiscal Compact treaty while experiencing falling domestic popularity (see Chapter 2). The Two-Pack legislation in itself had also inspired less protest and fervour amongst Europe's disenfranchised than preceding chapters of economic governance reform. While the European Left had managed to rally together a number of demonstrations against the Fiscal Compact in early 201277, the reforms enhancing fiscal surveillance and increasing budgetary oversight failed to gain much publicity. This was perhaps a result of the Two-Pack legislation being sold as an 'add-on' to the already agreed Six-Pack. There were also fewer public recriminations offered by the various parties during the negotiation period in this case, as the Parliament and Council jostled predominantly behind closed-doors in order to concede as little as possible in the final text, which undoubtedly contributed to a much less vitriolic response from opponents to austerity. This combination of factors did Social Europeans no favours in their efforts to forcefully place their mark on another significant piece of economic governance reform.

\subsection{Edging towards Eurobonds: does 'no' mean 'no' for the Right?}

The passing of the Two-Pack had seen the European Parliament become more involved in economic governance reform than at any point during the debt crisis. Despite this, it could scarcely be argued that the concessions gained in the final text had truly represented a turning point in the EU's political economy. The view of the author of this thesis is that it was not the outcome of the Two-Pack negotiations, but the ability to maintain and elevate the debate surrounding Eurobonds that became the primary achievement of the European Left. This allowed Social Europeans to gain a foothold in the discussion surrounding further economic reform and push the debate away from a heavily austerity-centric approach.

The idea of mutualising European debt had been slated as a potential recovery mechanism, and future anti-crisis protection tool, at a very early stage in the reform

77EurActiv.com $\left(26^{\text {th }}\right.$ January, 2012) " Trade unions plan pan-EU action against fiscal compact", available: http://www.euractiv.com/socialeurope/trade-unions-plan-pan-eu-action-news-510386 
process. A number of proposals were put forward as full-scale panic was setting in over the European economy during 2009 and the early months of 2010. The first idea to receive considerable coverage was the 'Blue Bonds' proposal issued through the Brussels-based economic think tank Bruegel. The paper, authored by Jacques Delpha and Jakob von Weizsäcker, distinguished itself from earlier versions by partially pooling European liabilities while ring-fencing higher levels of debt to remain in the hands of individual member states. ${ }^{78}$ The proposal acted as a precursor to the GCEE's call for a European Redemption Fund, as it introduced the notion of incentivising sustainable national economic policies by collectivising debt below 60 per cent of GDP, while punishing countries on "reckless borrowing path(s)" above this level through the unavoidably higher interest rates on remaining debt. ${ }^{79}$ The Blue Bonds proposal would join the GCEE report and the Commission's Green Paper as oft-cited reference points for supporters of Eurobonds during an on-going debate which was to intensify as the economic governance reform process moved along.

\section{2.i Why Eurobonds? The anti-austerity balancing tool}

The Eurobonds issue has come to epitomise the two sides of the European economic debate and the battle between the two competing visions for an ever closer union. The Left's on-going frustration at the austerity-first approach to reform was well expressed by Green MEP Marijie Cornelissen in the lead up to Parliament's battle with the Council over Eurobonds in 2012. Cornelissen noted that the existing approach to economic legislation belied the divergence in viewpoints within the political machinery in Brussels and beyond, and called for Europe to reconcile its two faces by basing reform not only on reducing costs "but also (on) enhancing welfare." 80 The Dutch MEP claimed the tension between ministers within the EU institutions was not being addressed by the European Council, which had "mainly

\footnotetext{
78 Delpha, J. and von Weizsäcker, J. (2010), The Blue Bond Proposal, Bruegel policy brief issue 2010/03, Brussels, page 4. Paper, available: http://www.bruegel.org/publications/publicationdetail/publication/403-the-blue-bond-proposal/

${ }^{79} \mathrm{Ibid}$, page 2.

80 Marijie Cornelissen (28 th February, 2012), "Europe needs to reconcile its two faces", available: http://euobserver.com/opinion/115391
} 
ignored most of the messages coming from those dealing with employment and social affairs, and only endorsed the ones proclaiming fiscal stability." 81 Moreover, she correctly pointed out that proposals within the governance structure for launching a "social recovery" had been vague and "merely repeated former commitments" ${ }^{82}$ This was in sharp contrast to the binding commitments made to tougher rules on budgetary discipline across the EU. ${ }^{83}$

Throughout the reform process, the introduction of Eurobonds had been seen by many as a potential method of balancing out new austerity-centric economic legislation. The basic effect of such a scheme would be to lessen the debt burden on the peripheral European economies battling to stay afloat, by allowing them to participate in a collectivised system where at least a good proportion of their liabilities would be guaranteed by all of the Eurozone countries. Whether the scheme was to be applied presently or only for future debt, the hope is it would pave the way towards recovery for struggling member states, while lessening the economic imbalances within the EU. Supporters of debt mutualisation argue it would prove effective in a number of ways:

a) Lowering the cost of borrowing for indebted states:

The creation of a Eurobond would significantly lower interest rates for highly indebted member states thereby lowering the cost of borrowing. The bond yield resulting from a total or partial pooling of European debt would likely even be lower than the weighted average of national yields. ${ }^{84}$ Currently, high yields are preventing southern member states from accessing capital and from investing public funds to stimulate their ailing economies. ${ }^{85}$ Eurobonds would give struggling countries the

\footnotetext{
${ }^{81}$ Ibid.

82 Ibid.

${ }^{83}$ Ibid.

${ }^{84}$ Delpha, J. and von Weizsäcker, J. (2010), The Blue Bond Proposal, page 2.

${ }^{85}$ Collignon, S. (2011), Eurobonds: the financial equivalent of the single currency - briefing note, European Parliament, Brussels, page 22, available:

http://www.europarl.europa.eu/document/activities/cont/201103/20110316ATT15716/20110316A TT15716EN.pdf
} 
ability to ease down current levels of unsustainable debt and provide easier and cheaper access to the financing of budgetary stimulus programmes. ${ }^{86}$

b) Increasing liquidity in the Euro area

A Eurobond would be a highly liquid asset with a large volume of available debt. Countries like Greece have become at risk of being insolvent, as a lack of liquidity in national bonds (alongside the high rates of risk) has led investors to pull out of periphery bond markets. ${ }^{87}$ However, a Eurobonds scheme would allow struggling countries to issue bonds in a highly liquid and safe market in which investors' confidence would be restored, due to the reassurance that the stronger economies would be forced to foot the bill should the issuing country default. ${ }^{88}$ Moreover, the amount of debt available would help the Euro's rise as a "second global reserve currency", rivalling the US Treasury bond. ${ }^{89}$

c) Providing incentives for fiscal discipline

The introduction of Eurobonds would provide countries with high debt levels the incentives to become more fiscally disciplined, in order to be eligible for the scheme. As most of the serious proposals being discussed come with conditions attached based around adherence to existing or new fiscal rules, this would also help to reestablish the credibility of the SGP, as well as fiscal rules set down in the other strands of European economic governance laws. ${ }^{90}$ Additionally, the incentives for fiscal stability could be reoriented "away from the dubious 'stick'-based system of fines and sanctions and towards a 'carrot'-based system of benefits for those states that can prove themselves to be fiscally sound." 91

\footnotetext{
${ }^{86}$ De Grauwe, P. and Mosen, W. (2009), Gains for All: A proposal for a common Eurobond, page 3.

87 Collignon, S. (2011), Eurobonds: the financial equivalent of the single currency

88 EUCE North Carolina (2012), "Policy Area: Eurobonds", EU Briefings May 2012, University of North Carolina at Chapel Hill, available: http://europe.unc.edu/wpcontent/uploads/2013/08/Brief1205-eurobonds.pdf, page 4.

${ }^{89}$ Delpha, J. and von Weizsäcker, J. (2010), The Blue Bond Proposal

90 Delpha, J. and von Weizsäcker, J. (2010), The Blue Bond Proposal

${ }^{91}$ EUCE North Carolina (2012), “Policy Area: Eurobonds”, EU Briefings May 2012, page 6.
} 
d) Mitigating the 'flight to safety' syndrome

As well as easing investors' concerns by providing additional liquidity, Eurobonds would also mitigate against the 'flight to safety syndrome' that currently disrupts the European bond markets. ${ }^{92}$ The likes of Greece and Ireland are often shut out of the financial markets as their debt is viewed as too risky. ${ }^{93}$ As a result buyers seek out safer bonds in Germany and, to a lesser extent, France. If the divided debt or Blue and Red bond proposals were put in place, markets would define the boundary between safe and risky assets in terms of debt level as opposed to nationality. Investors would thus be able to move their money into higher quality debt in the same country rather than needing to look towards a different country altogether. ${ }^{94}$

e) Aiding the banking system and the private sector.

A joint liability scheme would improve financial market stability and as a result allow the ECB to focus on the overall functioning of monetary policy operations. ${ }^{95}$ Eurobonds would also provide a source of more robust collateral for all banks in the Euro area, reducing their vulnerability to deteriorating credit ratings in poorly performing member states. ${ }^{96}$ Without the fear of 'liquidity bottlenecks ${ }^{97}$, banks would be more able to fund private investment, which would in turn help to create economic growth..$^{98}$ The private sector could benefit further from the introduction of Eurobonds, especially if their design was along the lines of the EU 'project bonds' proposed by José Barroso, which would be used to create public-private partnerships to increase the number of growth-spurring investments. ${ }^{99}$

\footnotetext{
${ }_{92}$ De Grauwe, P. and Mosen, W. (2009), Gains for All: A proposal for a common Eurobond, page 3. 93 Ibid.

94 EUCE North Carolina (2012), "Policy Area: Eurobonds", page 5.

${ }^{95}$ Schwarzer, D. (2014), "The European Parliament and Eurobonds: Keeping the debate going", in: Strengthened, sidelined and caught in compromise - The $7^{\text {th }}$ EP from a German perspective, Stiftung Wissenschaft und Politik - German Institute for International and Security Affairs, Berlin, page 20, available: http://www.swp-

berlin.org/fileadmin/contents/products/arbeitspapiere/SWP_Report_NEJDI_VoteWatch_Europe_E P_elections.pdf ${ }^{96}$ European Commission (November 23rd, 2011), “European Commission Green Paper on the feasibility of introducing Stability Bonds"

${ }^{97}$ A liquidity bottleneck is a sudden drying up or loss of liquidity.

98 Collignon, S. (2011), Eurobonds: the financial equivalent of the single currency, page 21.

${ }^{99} \mathrm{Ibid}$, page 10.
} 
Other important advantages to creating a debt mutualisation scheme have been occasionally put forward by advocates. These include the prevention of disruptive speculative attacks on financially struggling countries ${ }^{100}$, increasing the integrity of a monetary union which arguably does not currently meet the criteria for an optimum currency area (as noted in Chapter 1) and the restoration of trust in the EU between member states, within financial markets and between citizens. ${ }^{101}$

\section{2.ii The German-led opposition: a risk too great}

The debate over Eurobonds has been at times at the fringes during economic governance reform, and at other times placed front-and-centre by opponents to the existing ordoliberal orthodoxy. Throughout the entire process however, the introduction of any debt mutualisation scheme has been met by resolute opposition from one key source: Angela Merkel and the German Government. While Germany under Merkel has been rhetorically supportive of more integration in the EU and the idea of an altogether closer union, this sense of collective spirit has never threatened to extend to compromise in the realm of economic policy, particularly in regard to Eurobonds. 102 The dichotomist approach that characterises the consolidation coalition's vision for integration was captured in 2012 with Wolfgang Schäuble's pleas for "bigger steps in the direction of a fiscal union"103 complemented by Merkel's refutation of the merits of debt mutualisation, stating that Eurobonds were "exactly the wrong answer to the current crisis" and would turn Europe into "a debt union and not a stability union."104

A proposal for Eurobonds put forward by then-Luxembourg Prime Minister JeanClaude Junker and Italian Finance Minister Giulio Tremonti received a frosty reception from Germany and its allies in the European Council at the summit in

\footnotetext{
100 Beetsma and Mavromatis (21 st December 2012), “Eurobonds: The design is crucial”, available: http://www.voxeu.org/article/eurobonds-design-crucial

101 Ibid.

102 Chapter five will explore Germany's historic and present day commitment to a closer European Union and draw conclusions on its effect on the political future of the continent.

103 EurActiv (October 16 $\left.{ }^{\text {th }}, 2012\right)$, "Schäuble urges big leap forward on 'fiscal union'”, available: http://www.euractiv.com/future-eu/schaeuble-urges-big-leap-forward-news-515438 104 EUCE North Carolina (2012), "Policy Area: Eurobonds", page 6.
} 
December 2010.105 Opponents claimed, and continue to claim, that any joint liability scheme would result in punishing the fiscally sound 'non-crisis countries' while rewarding less responsible governments by allowing them to continue profligate spending patterns. ${ }^{106}$ In more detail, the primary arguments used to counter the issuance of Eurobonds are as follows:

\section{a) Creating moral hazard}

A pooling of sovereign debt would create moral hazard and lead to a free-riding problem. ${ }^{107}$ Increasing the availability of bonds and lowering interest rates would not encourage struggling member states to become more fiscally disciplined, rather it would provide the likes of Greece, Portugal, Ireland and Italy with fewer incentives to conduct sustainable fiscal policies, thus resulting in greater levels of spending and higher amounts of debt in 'crisis countries'. ${ }^{108}$ Even some advocates for Eurobonds admit that the conversion of national debt into joint debt poses enormous moral hazard concerns. These concerns may not be simply allayed by creative construction of a mutualisation scheme that divides debt into European and national tranches, as the interest rate on the guaranteed component of the debt would be largely insensitive to an individual debt increase. ${ }^{109}$ This would therefore fail to create an incentive for countries to stop borrowing at unsustainable levels, something which most proposals are trying to achieve.

b) Anti-re-distribution: hurting fiscally responsible governments

A debt redemption or Eurobonds plan would re-distribute resources away from countries with sound public finances towards countries which have failed to keep their books balanced or their debt levels in check. This would result in the taxpayers

\footnotetext{
105 Erik Jones (2011), “In defence of Eurobonds”, in E! Sharp magazine - March-April issue, available: http://www.jhubc.it/facultypages/ejones/eurobond.pdf 106 Ibid. 107 Schwarzer, D. (2014), “The European Parliament and Eurobonds: Keeping the debate going”, page 20.

108 De Grauwe, P. and Mosen, W. (2009), Gains for All: A proposal for a common Eurobond, page 3.

109 Beetsma and Mavromatis (21 st December 2012), "Eurobonds: The design is crucial"
} 
of countries such as Germany becoming liable for other countries' debt.110 Furthermore, Germany would not benefit from the low Eurobond interest rate as Bund yields have been comparatively low to what is likely to be offered under a joint liability scheme. 111 The German Finance Ministry has estimated that the country would pay an extra 80 basis point premium over present rates, at a cost of $€ 20-25$ billion over the next 10 years. ${ }^{112}$

c) Eurobonds place within the economic governance structure

A joint debt structure would not fit well into the existing European economic governance framework. A consensus exists among Eurobond detractors, particularly in northern Europe, that the imposition of fiscal discipline is the way to solve the crisis (as has been outlined in this thesis). ${ }^{113}$ Any sensible preconditions for the issuance of Eurobonds have not been met and a sustainable fiscal framework must first be put in place to avoid the issues of moral hazard and free-riding. ${ }^{114}$

d) Constitutional concerns and the 'no bailout' clause

The idea of Eurobonds raises concerns over democratic accountability and constitutional legitimacy. ${ }^{115}$ Many, if not most, versions of joint liability schemes that have been put forward would likely require a change to EU treaties (some supporters of mutualisation agree). A Eurobonds scheme would necessarily involve the removal or adaptation of the 'no bailout' clause - preventing fiscal transfers between sovereign nations - under which so much European economic reform has been based. ${ }^{116}$ The German constitution, and likely some other national

\footnotetext{
110 Benjamin Fox (20th February, 2012), "EU deal on Eurozone rules after MEPs back down on debt fund", available: http://euobserver.com/economic/119129

111 The 'Bund' is the national bond issued by the Deutsche Bundesbank (German central bank), source: http://www.investopedia.com/terms/b/bund.asp

112 EUCE North Carolina (2012), "Policy Area: Eurobonds", page 6.

113 Ibid, page 4.

114 Schwarzer, D. (2014), “The European Parliament and Eurobonds: Keeping the debate going”, page 20.

115 Ibid.

116 Ibid.
} 
constitutions, would also have to change in order to reverse limits on competence transfers and shared liability laws. ${ }^{117}$

\section{2.iii The tide had changed: just a matter of time}

The German resistance to Eurobonds has been equal parts about power, ideology and self-interest, as it has been about Angela Merkel's government's concerns for the future of the Eurozone. Germany has led a stern and uncompromising opposition to Eurozone debt mutualisation throughout the Sovereign Debt Crisis, but it looks unlikely to be enough: it seems that at some point over the next few years, Germany will have to compromise to an extent they have not yet experienced during the reform process and take the plunge on some form of debt pooling scheme. At the time of the European Parliamentary elections in 2014, the move towards Eurobonds was looking increasingly inevitable, whether their introduction would be two, five or 10 years away. In order to explain why this is the case, the rest of this section will examine how Eurobonds shifted from being an unpopular proposal in 2010, to a means of alternative reform firmly supported in many quarters today. Subsequently, Chapter Four will discuss how Eurobonds and other priorities for the Left continue to play a crucial role in Germany's struggle between its commitment to an austeritybased European economy and its desire to hold the union together.

Germany's dismissal of debt mutualisation had been long known prior to the wave of proposals for implementing Eurobonds were released and increasingly put under the microscope as the crisis wore on. The well-understood "fact of life"118 for austerity antagonists was that the German commitment to sound money, price stability and fiscal conservatism is deeply rooted and certainly not a historical anomaly (see Chapter 1). ${ }^{119}$ Many of the proposals took the German position into account, seeking to find a compromise that would not necessarily place the bill for Europe's economic recovery firmly at the feet of Merkel's government. Early in the

\footnotetext{
117 Ibid.

118 De Grauwe, P. and Mosen, W. (2009), Gains for All: A proposal for a common Eurobond 119 Open Europe (November 23rd, 2011), "Eurobonds or ECB... Either way Germany has to pay the bill", available: http://openeuropeblog.blogspot.co.nz/2011/11/eurobonds-or-ecb-either-waygermany-has.html
} 
reform process, Merkel was not short of allies in her position on Eurobonds. In fact during 2010 and throughout most of 2011, there seemed little appetite for the idea: the presidents of the Council and ECB, as well as the leaders of Europe's two biggest nations after Germany - France and Italy - all publicly refuted suggestions that a collectivised debt issuance scheme should be part of the package to save Europe. In late 2011, Herman Van Rompuy stated his belief that the time was not right for such a move and that further budgetary convergence and more rigorous stability mechanisms were the way to solve the crisis. ${ }^{120}$ Italian Prime Minister Mario Monti claimed that levelling interest rates through joint bond issuance gave "the wrong signal"121 to struggling member states while Nicholas Sarkozy balked at the idea, arguing that "countries should be given responsibilities, not have them taken away."122

The views of Europe's most powerful policy-makers were unsurprising, given the faith most of the political elite had placed in increasing fiscal oversight and enhancing consolidation as the key components to solving the crisis. In producing their proposal for a redemption fund, the GCEE noted in late 2011 that the respective positions on the issue appeared to be "almost impossible to reconcile" with "proponents of solidarity stunned that their Eurozone peers let them stand in the rain even at the risk of their own peril". ${ }^{123}$ Other supporters lamented prior to the French presidential election that the German opposition to collective liability appeared “insurmountable". ${ }^{124}$

The real turning point for Eurobonds came, again, with Francois Hollande's electoral victory, and it was clear the mood had changed when the French President departed from his first EU summit in late May 2012. While the issue had been reignited by the Commission's Green Paper - Barroso had come to the party on Eurobonds following

\footnotetext{
120 Terrance Roth (August 22nd, 2011), "Van Rompuy cautions against Euro Bonds", available: http://online.wsj.com/news/articles/SB10001424053111903461304576522352217712220

${ }^{121}$ Leigh Phillips (November 25th, 2011 ), "Italy sides with Germany against eurobonds", available: http://euobserver.com/economic/114403

122 Thelocal.de (December 10th, 2010$)$, “Merkel and Sarkozy team up against Eurobonds", available:

http://www.thelocal.de/20101210/31735

123 GCEE (November 9th, 2011), "A European Redemption Pact"

124 EUCE North Carolina (2012), “Policy Area: Eurobonds”, page 6.
} 
his earlier timidity ${ }^{125}$ - and the GCEE report in the latter months of 2011, the European Left needed a champion for change. Hollande had given the anti-austerity movement in Europe a powerful voice, and his activism on economic reform extended into the realm of debt mutualisation.

Despite German insistence that Eurobonds would not be on the table for discussion prior to the Summit ${ }^{126}$, Hollande ensured the EU leaders' meeting on May 23rd was dominated by the issue. The French president's vision for growth in the Eurozone very much included the creation of a joint debt mechanism and with supporters for Hollande's demands greatly increasing in number and boldness, officials said the inescapable feeling from the meeting was one of a shift in power towards the French and away from the austerity-focus that had shaped discussions over the past two years. ${ }^{127}$ In fact, it was the first EU summit in years that had not been dominated by Merkel, and the schism between France and Germany was plain for all to see, with the leaders of the two countries declining to meet ahead of the event to agree a common position. ${ }^{128}$ This marked a complete departure from the strategy undertaken by the Eurozone's two biggest powers during the Merkozy pact. ${ }^{129}$

Hollande's domination of the EU summit in May, where Eurobonds were discussed by EU leaders seriously for the first time, helped to transform a mere molehill for Germany into a moderate, but irritating mountain. ${ }^{130}$ Merkel stood firm on the issue and was, at times, particularly explicit in her defiance.

\footnotetext{
125 European Commission (December 14 $\left.4^{\text {th }}, 2010\right)$, “European Parliament Question Hour”, available: http://ec.europa.eu/commission_2010-2014/president/about/question/index_en.htm 126 Ian Traynor and Patrick Wintour, "Eurozone crisis: Germany and France clash over Eurobonds at summit", available: http://www.theguardian.com/business/2012/may/23/eurozone-crisis-francegermany-divide

127 Ibid.

128 Carsten Volkery (May 24th 2012 ), “France Dominates EU Summit: Hollande Steals the Show from Merkel"

129 Ibid.

130 Sofia Kovacheva (23rd May, 2012), “Eurobonds Are Again Coming Into Fashion”, available: http://www.euinside.eu/en/analyses/eurobonds-back-in-vogue
} 


\section{Table Two: The shifting climate's effect on Eurobonds}

\section{1}

2014
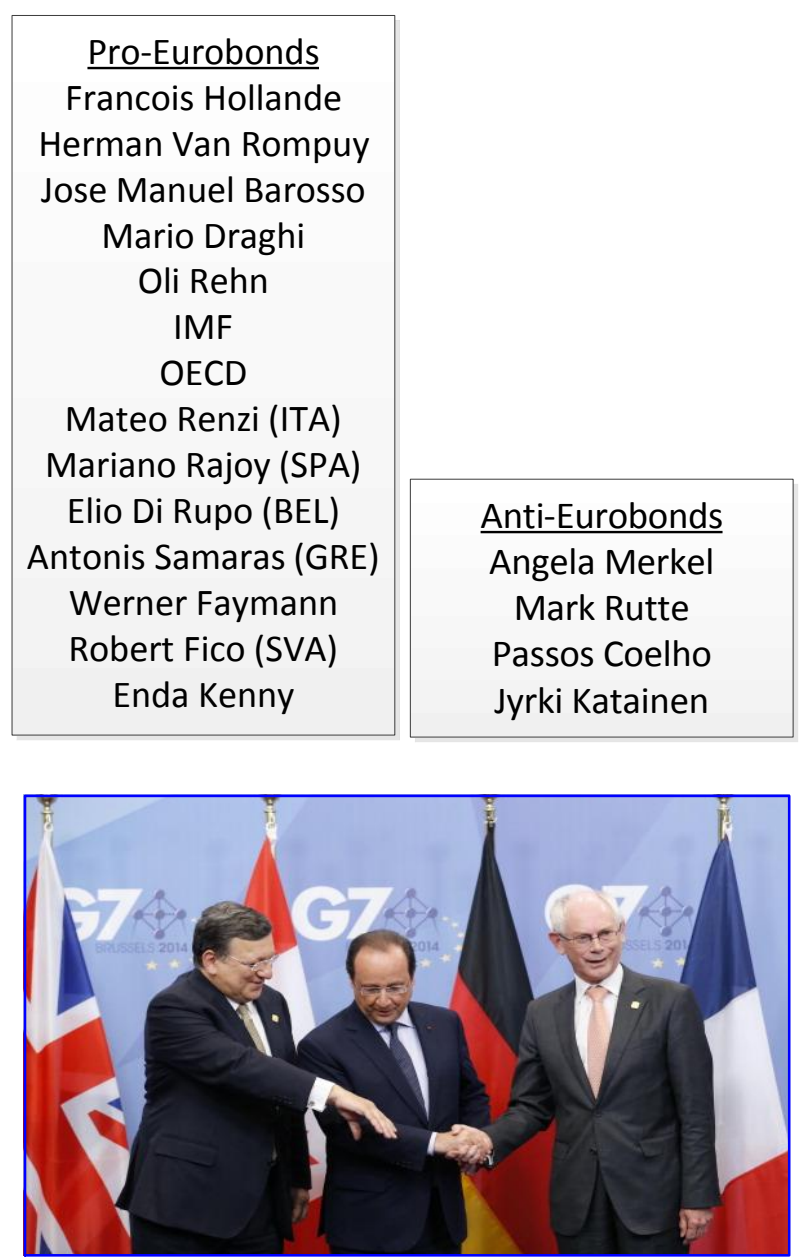

She ramped up the rhetoric when confronted by members of her government on the issue a month later, stating that "there will be no shared total debt liability for as long as I live."131 This angry response had been influenced by Herman Van Rompuy's decision to set down Eurobonds as a discussion topic for the next leaders' summit on June $28^{\text {th }}$, having himself joined the ever-growing pool of influential European politicians to endorse some form of debt pooling (see Table Two). ${ }^{132}$ The fact was that Germany's allies on the issue were rapidly retreating and taking an

131 Open Europe (26 $6^{\text {th }}$ June, 2012), "Merkel comes out swinging against debt pooling", available: http://openeuropeblog.blogspot.co.nz/2012/06/merkel-comes-out-swinging-against-debt.html 132 Van Rompuy, H. (26 th June, 2012), Towards a Genuine Economic and Monetary Union - Report by President of the European Council, Press release, Brussels, page 4, available: http://www.consilium.europa.eu/uedocs/cms_Data/docs/pressdata/en/ec/134069.pdf 
alternative view: a trend which would only continue as Europe edged towards the all-important elections in 2014.

Before being subjected to the rigours of an election campaign, the Seventh European Parliament played a crucial part in the slow but sure drift towards Eurobonds. Seizing upon the shift in the political climate after Hollande's victory, the left faction managed to keep Eurobonds firmly on the agenda throughout 2012 and into 2013. While the promise of an expert study on the 'feasibility' of introducing Eurobonds and a redemption fund was hardly a ground-breaking concession from the member states, the publicity surrounding its release served to increase the pressure on European leaders against the backdrop of a lifeless Eurozone economy in early 2014.

Though MEPs are often accused of being 'out of touch'133, their effectiveness in coming together on the issue of Eurobonds was typical of a compromise mentality that has set the European Parliament apart from an increasingly divided Council. MEPs from the four largest party groups in the plenary voted handsomely in favour of introducing Eurobonds by adopting Sylvie Goulard's Own-Initiative Report in 2013.134 This included 80 per cent of the centre right EPP voting for debt mutualisation and, intriguingly, nearly half of the MEPs from Merkel's CDU party in favour of the proposal in a bold break from the domestic party's position. ${ }^{135}$ The ideological compromises undertaken by political groups from the left and right factions of the European Parliament led to a much more balanced approach towards economic reform. While helping secure the Socialists' sign-off on increased budgetary surveillance and tighter fiscal rules, this approach has also led the Parliament towards taking a stance against Europe-wide austerity, with various reports from parliamentary committees warning that the existing approach presents the risk of a recessionary spiral with serious social consequences. ${ }^{136}$

\footnotetext{
133 Martin Banks (October 11th, 2013), "Gold medals given to retiring MEPs 'waste of taxpayers' money'", available: http://www.telegraph.co.uk/news/worldnews/europe/eu/10372065/Goldmedals-given-to-retiring-MEPs-waste-of-taxypayers-money.html 134 Schwarzer, D. (2014), "The European Parliament and Eurobonds: Keeping the debate going", page 20. 135 Ibid.

136 Marijie Cornelissen (28 th February, 2012), "Europe needs to reconcile its two faces"
} 
The growing consensus in favour of debt mutualisation is not one encapsulating only policy-makers in Europe. The issue has become the standard bearer for the European Left and anti-austerity movement, but the dire economic state of the union has undoubtedly served to keep interested parties not directly responsible for reform - such as academics, commentators and stakeholders outside of the EU - invested in the idea of collectivised debt redemption in Europe. As voters went to the polls to have their say in the European elections in late May 2014, Eurozone unemployment stood at 11.7 per cent, only 0.3 per cent below the record high in 2013. ${ }^{137}$ While developed countries around the world were experiencing slow but steady recoveries from a global economic crisis five years removed from its low-point, growth in the Eurozone was an anaemic 0.2 per cent. ${ }^{138}$ With much of the positive activity coming in Germany, the economies of southern and eastern European countries - as well as struggling France - were not close to creating the revenue required to address spiralling debt levels in any serious way. The confirmation that Greece had finally reached a primary surplus in April was met with relief, but belittled by the fact that the country's debt had reached a staggering 175 per cent of GDP.139

While other proposals for growth facilities, public investment funds and, more prominently, relaxed budgetary rules have featured heavily in the debate, the Eurobonds issue has simply refused to go away. As well as it being seen as both a short and long term solution for the Eurozone's inequities, much of the reason for this can be put down to the number of issues the proposed schemes seek to address and the amount of compromise already inserted into the plans for joint debt issuance, making it more likely such a scheme would eventually find consensus within the many layers of policy-making in the EU.140

\footnotetext{
137 Trading economics, "Euro Area Unemployment Rate"

138 Trading economics, "Euro Area GDP Growth Rate"

${ }^{139}$ Graeme Wearden (April 23 $3^{\text {rd }}$, 2014), "UK hits deficit target, Greece posts a primary surplus", available: http://www.theguardian.com/business/blog/2014/apr/23/chinese-factory-output-pmipublic-finances-greece-live

140 Barbara Ottawa (February 7th, 2012), "Eurobonds should be long term, 'even permanent', solution", available: http://www.ipe.com/eurobonds-should-be-long-term-even-permanentsolution/43960.fullarticle
} 
Those now calling for the adoption of Eurobonds include Christine Lagarde at the IMF, ${ }^{141}$ as well as the OECD. ${ }^{142}$ More and more of the commentariat has jumped on board the Eurobonds bandwagon, with leading think-tanks Bruegel and CEPS among the organisations providing their own proposals while many others continue to endorse debt mutualisation. Meanwhile, both Barack Obama and, perhaps more surprisingly, David Cameron have been open to the idea while suggesting that the Eurozone collectivise more economic responsibility if it is to recover. The American president's insistence to Angela Merkel that she 'ease up' on austerity measures in Europe at the G8 meeting in May 2012 further isolated the German Chancellor against a wave of popular opinion. This wave continued to swell in the two years following the May 2012 turning point before elections completely took over the EU agenda. By this stage it seemed the Merkel government was fighting a war, almost on its own, which threatened to seriously alienate Germany from its major neighbours, and outside allies such as the US. ${ }^{143}$

Despite the great momentum behind debt mutualisation in Europe, Eurobonds are not yet a done deal. At the time of writing, there have been no proposals agreed upon by each of the Parliament, Commission, Council and member states to create a joint debt issuance mechanism. It would likewise be misleading to state that the forces behind the implementation of such a scheme were now 'insurmountable' for opponents, as some Eurobonds protagonists had feared was the case on the other side of the ledger prior to May 2012. In fact there are some convincing arguments to suggest that supporters will continue to be frustrated in their efforts to create collectivised debt redemption in Europe. The best of these arguments centres on the ever present power of Germany and a conviction that joint bonds cannot and will not be adopted without its approval. Francois Hollande has made it clear he is reluctant to go forward with designing concrete proposals for Eurobonds without Merkel and is aware that a change to EU treaties - therefore unanimity amongst EU

\footnotetext{
${ }^{141}$ EUbusiness.com (January 23rd, 2012), "IMF head wants 'larger firewall', 'eurobonds' against crisis", available: http://www.eubusiness.com/news-eu/finance-public-debt.epp

${ }_{142}$ OECD (2012), OECD Economic Outlook, Vol. 2012/1, OECD Publishing, page 9, available: http://dx.doi.org/10.1787/eco outlook-v2012-1-en

${ }_{143}$ Reuters (June 19th, 2013), “Obama tells Merkel policies must improve lives", available: http://www.reuters.com/article/2013/06/19/us-obama-berlin-jobs-idUSBRE95I0Y620130619
} 
leaders - would most likely be necessary to see them through. ${ }^{144}$ Additionally, there is no denying Germany continues to 'hold the purse strings' in Europe. Already the largest contributor to the bailouts, Germany would in many Eurobonds schemes again be the economic force behind debt guarantees. This idea has been exaggerated in some circles: while Open Europe and other anti-federalists have repeatedly suggested collectivised issuance would require German taxpayers to underwrite "the whole party"145, the GCEE redemption fund proposal, for example, would actually expect Italy to contribute the greatest amount to the $€ 2.3$ billion fund. ${ }^{146}$

Some believe Germany will never cease to hold their position against Eurobonds and the adoption of more lenient budgetary measures due to a historically-consistent ideological edifice that separates the country from the rest of Europe. ${ }^{147}$ Moreover Angela Merkel has for the most part reacted to her unpopularity across the Continent with little anxiety. ${ }^{148}$ Opponents of debt mutualisation have also argued that the impact of the pro-Eurobonds movement has been felt mainly in political circles in Brussels and has made little impact on the outside world. As such, they claim this concentrated fuss is never remotely likely to overcome the principle concerns of opposing member states. ${ }^{149}$

The arguments against the inevitability of change are legitimate. There is no doubt that the German opposition to Eurobonds provides the ultimate obstacle to their introduction. However, it must be noted that there are some who believe Merkel has played her cards in a certain way as to leave the door slightly ajar for the adoption of such a scheme in the future. While many of her public statements have been forthright about the dangers of debt mutualisation, she has certainly given slightly

\footnotetext{
${ }^{144}$ Carsten Volkery (May 24 $4^{\text {th }}$, 2012), “France Dominates EU Summit: Hollande Steals the Show from Merkel"

145 Open Europe (November 23rd, 2011), “Eurobonds or ECB... Either way Germany has to pay the bill"

146 GCEE (November 9th, 2011), "A European Redemption Pact”.

147 Dullien, S. and Guérot, U. (2012), The Long Shadow of Ordoliberalism: Germany's Approach to the Euro Crisis, ECFR policy brief, London, page 1, available: http://www.ecfr.eu/page/-

LECFR49_GERMANY_BRIEF.pdf

148 Ibid.

149 Schwarzer, D. (2014), “The European Parliament and Eurobonds: Keeping the debate going", page 21.
} 
different messages to different audiences on the issue. Merkel's 'over my dead body'-esque refusal in mid-2012 was delivered in front of her Government's junior coalition partner at the time, the right-wing FDP. ${ }^{150}$ The claim she made actually denounced the possibility of "shared total debt liability", which alongside her spokesman's insistence that Germany was "not there yet"151 on the issue, left open the possibility that a more balanced option - such as the Blue bonds proposal or GCEE plan - could be a possibility down the track. Two days later before the EU summit Merkel stated that "joint liability can only happen when sufficient controls are in place"152, suggesting further that there may be light at the end of the tunnel for Social Europeans, at least when Germany is happy with the state of fiscal rules in the Eurozone. Moreover, it should be noted that complementing the German economic ideology demanding stability above all else, is a convincing logic that joint debt issuance should become much easier with firm rules in place. As mentioned in many of the more balanced proposals, economically strong member states underwriting debt will be much more comfortable in a scenario where their contributions are only financing more moderate levels of liability.

Furthermore, claims that a strong anti-Eurobonds coalition still remains in force outside of Germany are starting to diminish the credibility of opponents. For example, Daniela Schwarzer's claim of "an outright rejection of Eurobonds in a number of member states" falls wide of the mark. While the Prime Minister of Portugal, Pedro Passos Coelho, continues to stand by the German position - against heavy domestic opposition ${ }^{153}$ - come June 2014, Finland and Holland were the only other remaining Eurozone countries not in support of some form of Eurobonds scheme. ${ }^{154}$

\footnotetext{
150 Open Europe (26 th June, 2012), “Merkel comes out swinging against debt pooling". 151 Ibid.

152 EurActiv (June 28 th 2012), "Merkel insists on fiscal union before debt sharing", available: http://www.euractiv.com/euro-finance/merkel-insists-fiscal-union-debt-news-513613 153 Pedro Carreira Garcia (May 24th, 2012), "EU Summit: Portugal's Prime Minister sides with Germany on 'Eurobonds'”, available: http://www.portugaldailyview.com/02-politics/summitprime-minister-sided-with-germany-about-eurobonds

${ }_{154}$ Carsten Volkery (May 24th, 2012), “France Dominates EU Summit: Hollande Steals the Show from Merkel"
} 


\section{3) Conclusion}

The Two-Pack process did not yield the concrete outcomes desired by the European Left and supporters of the Social European vision. It did, however, eventuate into a 15-month battle where the European Parliament forced its hand to mitigate the effects of more central control over struggling economies, and reinvigorate the debate surrounding Eurobonds. The corresponding shift in the political climate in Europe away from the Merkozy-enforced austerity-fixation led more and more European policy-makers to question the consolidation coalition's approach towards reform. While this shift barely made its mark on the Fiscal Compact, it has undoubtedly influenced the prospective move towards Eurobonds and a renewed concentration on greater economic integration in the Eurozone. These factors allowed Social Europeans to feel as though they had earned a victory in the year following the French election. Germany's vision for Europe appeared less sacred and less secure.

This chapter has discussed the developing debate over Eurobonds and legislative reform in Europe by examining the shifting political tide against consolidation and the changing positions of major players in Europe. The next chapter however, will turn away from a focus on economic governance to look at the effect of the crisis on another major political event on the Continent. The 2014 European elections represented what many believed would be a defining process in the history of the EU. The success of Eurosceptic parties in the election and the public disenchantment with the status quo has undoubtedly thrown a spanner into the works in European politics. The thesis will now examine the extent to which the rise of anti-European sentiment has positively affected the standing of the Eurosceptic vision, and ask whether an unlikely federalist alliance could provide the Left with another chance to shift economic reform away from its austerity-first focus. 


\section{European Elections 2014: An Unlikely Alliance Emerges}

"The Eurozone crisis is a dialogue of the deaf between two rival schools of thought"1

$$
\text { - Hugo Brady }
$$

They probably couldn't, and be shouldn't be called the 'comfortable crisis years' as they were anything but comfortable. But the period between late 2011 when the SixPack passed into law, and February 2013 when the troublesome Two-Pack became the latest piece of legislation, at least saw a European political landscape fully engaged in the notion of positive institutional change. As seen in the previous two chapters, this was a time of reforming the EU, not casting it aside; of more Europe, not less. However, the efforts to reform economic governance, which acted as the central tenants in the EU's response to the Continent's woes, were very much characterised by fierce debates over stability versus solidarity; of austerity versus growth. Compromises were never easily found, while both sides argued over the impacts of shifts in the political climate. Hugo Brady's description of the crisis was thus perfectly apt. Austerity advocates and Social Europeans certainly had trouble hearing each other as they fought tooth and nail for the advancement of their own visions for the Union. It seemed somewhat strange then, that upon approaching the European elections in May 2014, the main topic of conversation was not the success or failure of recent EU reforms. Nor was the agenda set solely for another chapter in the argument over austerity. Instead, the narrative in Europe in the long lead-up to election-time was about the undeniable rise in Euroscepticism across the continent.

This chapter will chart the rise of anti-European sentiment and explain how the vision for less Europe managed to gain such prominence. The explanations for Euroscepticism touched on in chapter 1 will be explored further in the context of the rise in anti-EU fervour since the crisis began. Accounts based on identity, economic loss and institutional distrust will all be considered. However, the second section of

\footnotetext{
${ }^{1}$ Hugo Brady (May 11th, 2012), "Ireland's fiscal treaty referendum: (More) fear and loathing in the eurozone?" CER briefing note, available: http://www.cer.org.uk/sites/default/files/publications/attachments/pdf/2012/bn_ireland_fiscal_ 11may12-5070.pdf
} 
the chapter will argue that instead of pushing Europe towards the brink of breakup, the recent wave of Euroscepticism could actually serve to be somewhat counterproductive towards its central vision, as the Union threatens to be pulled ever closer together by an unlikely alliance of federalist forces on the left and the right.

\subsection{Rise of the Eurosceptics}

On May 25th, 2014, it was revealed that voters across the continent had elected the most Eurosceptic assembly in the history of the European Community. ${ }^{2}$ The proportion of anti-federalist MEPs rose from 16.1 per cent before the vote to 22.6 per cent in the newly elected European Parliament. ${ }^{3}$ As the plenary sat for the first time on July 1 $1^{\text {st }}$, notable gains had been made by the British Tory party-led ECR (plus 13 seats), the anti-EU right-wing EFDD (plus 17 seats), while the number of nonattached Eurosceptic MEPs had risen by 19, close to a 60 per cent increase from the previous Parliament. ${ }^{4}$ The Eurosceptic gains had come at the expense of the 'establishment' parties, particularly the centre-right EPP which still retained the highest share of MEPs with 221, but had conceded a spectacular 53 seats. The centreleft S\&D did not fare quite as poorly, dropping five seats, while the pro-integration Liberals and Greens lost 17 and seven MEPs respectively.

Perhaps the most alarming feature of the Eurosceptic rise was the extent to which anti-EU sentiment dominated the election campaigns within the member states. Farright nationalists impacted voting in the UK, France, Denmark and Hungary in a manner few could have imagined half-way through the Parliament's previous term. ${ }^{5}$ Nigel Farage's UKIP and Marine Le Pen's Front National topped the polls for the

\footnotetext{
${ }^{2}$ Niall McCarthy (May 26 ${ }^{\text {th }}$, 2014), "Far-Right Leads Eurosceptic Earthquake", available: http://www.statista.com/chart/2293/far-right-leads-eurosceptic-earthquake/

${ }^{3}$ European Parliament (July 1st, 2014), "Results of the 2014 European elections", available: http://www.results-elections2014.eu/en/election-results-2014.html ${ }^{4}$ Ibid.

${ }^{5}$ Open Europe (May 26 th, 2014), “Anti-EU and protest parties across Europe on course to win almost a third of all seats in new European Parliament", available: http://www.openeurope.org.uk/Article/Page/en/LIVE?id=20114\#
} 
first time in British and French history. ${ }^{6}$ The Danish People's party also surged to top spot in the Scandinavian country. ${ }^{7}$ Meanwhile, encouraging gains were made by Eurosceptic parties in Finland, Sweden, Greece and Germany. ${ }^{8}$

\section{1.i Against the establishment: Vision for a European overhaul}

The European media began to take notice of the rise in Euroscepticism in mid-20119, yet the focus on the crisis, bailouts and economic reform meant it remained mostly in the background for the following 12 months. However European surveys showed the upward trend began well before this point, with a steady increase in anti-EU sentiment from the beginning of the economic downturn in 2007 to a record high of over 19\% in 2011. ${ }^{10}$ This trend was seized upon with glee by Eurosceptic parties in the UK, France, Austria, Finland, Sweden, Latvia, Lithuania, and even Italy and Germany.11 Throughout 2011 and 2012, these parties made significant inroads in political polls and in some cases stormed their way into national parliament.

In December 2012, Euroscepticism in Britain reached unprecedented levels with a poll finding 51 per cent of respondents would vote to leave the EU. ${ }^{12}$ David Cameron's promise of an 'in-out' referendum on Europe just four weeks later created a stir on the continent, and forced European leaders to come to terms with

\footnotetext{
${ }^{6}$ Andrew Griece and Nigel Morris (May 26th, 2014), “European election results 2014: Farage and Ukip top poll as Europe swings to the right", available:

http://www.independent.co.uk/news/uk/politics/european-elections-results-2014-sweeping-gainsfor-nigel-farages-ukip-deal-further-body-blow-to-main-parties-9434042.html

${ }_{7}$ Lars Eriksen (May 25 th , 2014), "Far-right takes victory in Danish European elections", available:

http://www.theguardian.com/world/2014/may/25/danish-peoples-party-triumphant-ineuropean-elections

${ }^{8}$ Open Europe (May 26th 2014 ), "Anti-EU and protest parties across Europe on course to win almost a third of all seats in new European Parliament"

9 Andrew Rettman (July 1st, 2011), "Polish leader raises alarm about 'new' Euroscepticism", available: http://euobserver.com/institutional/32578

10 This figure represents the proportion of Europeans surveyed who believed EU membership to be a bad thing. Source: Serrichio, F. et al (2013), "Euroscepticism and the global financial crisis", page 57.

${ }^{11}$ Reuters (June 15th, 2012), "Eurosceptics bid for national stage in Germany", available: http://www.reuters.com/article/2012/06/15/germany-eurosceptics-idUSL5E8HDG3J20120615 12 Tom Clark (December 26 $6^{\text {th }}, 2012$ ), “Euroscepticism growing among voters, Guardian/ICM poll finds", available: http://www.theguardian.com/world/2012/dec/26/euroscepticism-growingvoters-poll
} 
anti-European momentum in the UK. ${ }^{13}$ The Prime Minister had made his pledge for a referendum on EU membership - to be held in 2017 in the case of a second term being secured by his party - against the backdrop of increasing tension between the leadership and Eurosceptic Tory backbenchers. ${ }^{14}$ While many felt the 'softEurosceptic' Cameron had simply fallen prey to the internal pressures of his party, European leaders acted mostly with disdain towards the Prime Minister. The German and Austrian Foreign ministers criticised Cameron for his "cherry picking" approach towards the EU. ${ }^{15}$ Their Swedish counterpart was more damning claiming Britain wished to open up "a 28-speed Europe", which would lead to "no Europe at all. Just a mess." The French foreign minister mocked Cameron's "a la Carte" attitude by comparing his approach to joining a football club and asking to play rugby upon arrival. ${ }^{16}$

The planned in-out referendum in the UK represented the most consequential expression of the Eurosceptic vision in some time. Cameron's pledge included a promise to negotiate new terms for Britain's membership within the EU, which the voters would then choose to accept or reject at referendum. ${ }^{17}$ Essentially, it was a threat that amounted to "give us what we want or we are out" from the Conservatives. Despite this, there were few serious attempts made to brush off the popular surge in anti-European sentiment as simply a 'British disease'. The UK was by no means a Eurosceptic outlier: by May 2013 trust in the EU had fallen from +10 to -22 per cent in France, from +20 to -29 per cent in Germany, from +30 to -22 in Italy and, staggeringly, from +42 to -52 in Spain since the beginning of the crisis. ${ }^{18}$ The following year saw the tide building steadily in size and momentum as the

\footnotetext{
${ }^{13}$ Nicholas Watt (January 23rd, 2013), “EU referendum: In-out choice by end of 2017, Cameron promises", available: http://www.theguardian.com/politics/2013/jan/22/eu-referendum-2017david-cameron

14 the Guardian Editorial (January 23rd, 2013), "In-out referendum: Cameron's hokey-cokey", available: http://www.theguardian.com/commentisfree/2013/jan/23/eu-referendum-david-cameroneditorial ${ }^{15}$ BBC (January 23rd, 2013), "Cameron referendum speech: EU reaction”, available: http://www.bbc.com/news/world-europe-21159365 16 Ibid. ${ }^{17}$ Nicholas Watt (23rd January, 2013), “EU referendum: In-out choice by end of 2017, Cameron promises" ${ }^{18}$ Torreblanca, J. and Leonard, M. (2013), “The Continent-Wide Rise of Euroscepticism”, page 1.
} 
elections of May 2014 approached. Eurozone leaders and federalist MEPs dispelled the virtues of integration on the campaign trail before bracing for the inevitable. When the tsunami hit, it caused a "political earthquake"19 that rocked the Union from Brussels to Bratislava.

\section{1.ii Fed up with federalism or anti-austerity?}

Chapter 1.2 briefly discussed commonly held explanations for Euroscepticism. While it is not the purview of this thesis to wade too far into this historical debate, this section will examine the competing arguments over the cause of the Eurosceptic rise in the midst of the crisis. Key issues often cited include identity concerns, the 'democratic deficit', institutional distrust, economic loss and elitism. However, while there is agreement over many of the reasons for the rise, the contested part of the analysis lies in the debate over the extent to which it has been caused by antifederalist or anti-austerity attitudes.

The anti-federalist explanation relies heavily on the role that identity concerns have played in the most recent Eurosceptic wave. Extremist, mostly far-right parties are credited for encouraging, or reacting to, a surge in nationalist sentiment based on fears over the loss of sovereignty to the nation state. The strong performance of Front National in France appears to be testament to this view. Marine Le Pen's emphasis on French sovereignty and statehood has been at the centre of her party's appeal to the electorate. She has labelled the EU a "Trojan horse of ultraliberal globalisation... holding us back and condemning us to isolation." 20 Proponents of the anti-federalist justification have downplayed the role of economics in the Eurosceptic rise during the crisis.

Serrichio et al. argue in their analysis that during the turbulent GFC crisis years of 2007-2010, economic indicators were not directly involved in fostering Euroscepticism, but instead the period reinforced the role of national identity and

${ }_{19}$ BBC (May 26th, 2014), “Eurosceptic 'earthquake' rocks EU elections”, available: http://www.bbc.com/news/world-europe-27559714

${ }^{20}$ Euractiv.com (January 25th, 2013), “Euroscepticism: More than a British phenomenon", available: http://www.euractiv.com/sections/eu-elections-2014/euroscepticism-more-british-phenomenon$\underline{286609}$ 
political institutions as the primary explanations. ${ }^{21}$ Their examination of Eurobarometer survey results in 2011 led them to claim that Euroscepticism was only strongly related to a negative evaluation of the economy in four countries: Greece, Portugal, the UK and the Czech Republic. ${ }^{22}$ Leconte adds to this line of analysis, by arguing that the perceived threats to the nation state by the promise of more Europe play a major role in anti-European sentiment. ${ }^{23}$ She contends that the "Communitization" of certain policy areas, particularly those with potential implications on redistribution and on deeply held societal preferences, may loosen or disrupt ties between member states and citizens. ${ }^{24}$

There is broad agreement that the declining trust in the EU and its institutions has played a significant part in the reinvigoration of Euroscepticism. As Leconte argues, public perception of the perceived responsiveness, transparency and trustworthiness of EU institutions has significantly influenced turnout and voting behaviour in EU elections and referenda. ${ }^{25}$ Thus, the hugely negative swing against the EU on its trustworthiness rating prior to the election no doubt played a major role. Advocates of the anti-austerity explanation argue that this is not the result of general 'integration-fatigue' or an inherent lack of belief in the EU as a political union; rather it is an expression of dismay in European institutions' inabilities to effectively tackle the crisis. ${ }^{26}$ This take on the crisis seeks to explain the Eurosceptic rise as primarily an outcome of economic disarray and resulting public disillusion. John Palmer has claimed that the "growth in support for far-right... has been fed by the worst world recession since at least the 1930s - mass unemployment and falling living standards, made worse by the self-defeating austerity obsession of European leaders."27 The EU-level reform of economic governance aimed at alleviating the crisis has, after all,

\footnotetext{
${ }^{21}$ Serrichio, F. et al (2013), "Euroscepticism and the global financial crisis", page 61.

22 Ibid.

${ }^{23}$ Leconte, C. (2010), Understanding Euroscepticism, Palgrave Macmillan, Hampshire, page 179.

${ }^{24}$ Ibid, page 162.

${ }^{25} \mathrm{Ibid}$, page 249 .

${ }^{26}$ Cecile Leconte (November 15th, 2011), “Debunking Myths about Euroscepticism", available: http://www.social-europe.eu/2011/11/debunking-myths-about-euroscepticism/ 27 Shaun Harkin (June 19th, 2014), "The message of the European elections", available: http://socialistworker.org/2014/06/19/message-of-the-european-elections
} 
been based largely on fiscal consolidation and greater oversight over government expenditure (as explained in Chapters 2 and 3).

Moreover, the anti-austerity argument appears to be the only legitimate explanation for the rise of leftist parties in certain member states during the European elections. In Greece and Spain, left-wing political movements SYRIZA and Podemos respectively, made large gains against the backdrop of vitriolic opposition to austerity measures imposed by both the EU and national governments. ${ }^{28}$ Other economic explanations for the rise have emphasised both the 'creditor' and 'debtor' frustrations with the economic state of the union, noting that the likes of Germany, Finland and the Netherlands have experienced increased Euroscepticism due to opposition to the bailouts. ${ }^{29}$

The anti-austerity explanation is convincing for the most part but ultimately oversimplified. It doesn't account for the embedded nature of Euroscepticism prior to the crisis and, in particular, the surge in anti-European sentiment following failed treaty referendums in France and the Netherlands in 2005.30 One-size-fits-all justifications for Euroscepticism appear in general to be misleading. As Torreblanca and Leonard point out, anger over austerity may provide the best explanation in the PIIGS countries, while identity concerns dominate in the UK, Denmark and Sweden. ${ }^{31}$ More pragmatic, non-ideological cost-benefit approaches towards the EU leave countries like Finland, Poland and arguably the Czech Republic outside of these

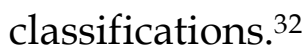

However, as noted in Chapter 1, explanations that remove economic concerns as a primary motivator for Euroscepticism remain unconvincing. The analysis provided by Serrichio et al. fails on two fronts. First of all, it does not effectively clarify the reasons for the upwards trend in Euroscepticism from 2007. While it notes the crisis

\footnotetext{
28 Ibid.

${ }^{29}$ Torreblanca, J. and Leonard, M. (2013), “The Continent-Wide Rise of Euroscepticism”, page 1.

30 Startin, N and Krouwell, A. (2013), "Euroscepticism Re-galvanised: The Consequences of the 2005 French and Dutch Rejections of the EU Constitution", in: Cini, M. et al (ed) Journal of Common Market Studies, Volume 51, issue 1, Blackwell Publishing, pages 72-73.

31 Torreblanca, J. and Leonard, M. (2013), “The Continent-Wide Rise of Euroscepticism”, pages 2-5.

32 Ibid.
} 
"exacerbated" existing sources of anti-EU sentiment, it does not convincingly portray this as a non-economic effect or provide a justification for the lack of a similar spike in the more economically stable period of 2000-2007.33 Secondly, based on the data provided, the claim of a weak correlation between economic factors and Euroscepticism is sketchy, at best. Of the 11 countries found to be more Eurosceptic than the EU average, only two do not suffer from large dissatisfaction over national economic performance. ${ }^{34}$ Moreover, the large increases in Euroscepticism recorded between 2007 and 2011 were almost exclusively in the member states with poor perceptions of national economies such as Greece, Portugal, Spain and Slovenia. ${ }^{35}$ Crucially, a fault with the anti-federal explanation for the Eurosceptic surge is found in the latest Eurobarometer survey, which notes the hugely declining levels in trust for the EU, but also shows that 45 per cent of Europeans support the development of a 'federation of nation states' as compared to the 35 per cent who oppose it. ${ }^{36}$

\subsection{Europe's true believers: A series of grand coalitions}

The reaction to the European election results was one of alarm in many quarters. While pre-election polling had suggested such a result was well on the cards, several morning-after reports sought to claim the end of the EU in its current form. The New York Times suggested the "angry eruption of populist insurgency" was set to call into question "the very institutions and assumptions at the heart of Europe's post-World War II order". The French were clearly left reeling from the result, as the sheer weight of votes afforded to the nationalists came as a surprise. Prime Minister Manuel Valls' claim of a "political earthquake" acted as headline fodder for European and global press.

The election results were meaningful and captured an undeniable feeling of disillusionment across the continent. The Eurosceptic vision had been given a huge boost: UKIP leader Nigel Farage basked in his party's success, claiming an end to the

\footnotetext{
${ }^{33}$ Serrichio, F. et al (2013), "Euroscepticism and the global financial crisis", page 58.

${ }^{34}$ Ibid, page 59.

${ }^{35} \mathrm{Ibid}$, page 58 .

${ }^{36}$ European Commission (2013), "Public Opinion in the European Union: Standard Eurobarometer 80", available: http://ec.europa.eu/public_opinion/archives/eb/eb80/eb80_publ_en.pdf
} 
'inevitability' of European integration. ${ }^{37}$ Farage's sentiments were understandable and certainly defensible, as it appeared in the immediate aftermath that the 2014 election may have provided a watershed moment for the move away from an ever closer union. However the Eurosceptic excitement ignored the underlying strength of the status quo, with federalist parties holding onto a dominant majority in the European Parliament despite the results. More importantly, the governments of all the major Eurozone nations, led by Merkel, Hollande and Italian newcomer Matteo Renzi, remained unapologetically committed to European integration. ${ }^{38}$ There was a sense among all following May 25 th that the elections were a wakeup call, and that Europe must change. But the question remained: what kind of change? This section will argue that the rise of Euroscepticism is set to unite federalist factions, and in doing so create the kind of change nationalist advocates fear the most by pushing Europe further towards an ever closer union. Further to this, it will be argued that the evolving political landscape is perhaps set to benefit the Social European vision more than its competitors.

\section{2.i German politics: Merkel and the SDP}

Despite a resounding triumph for Angela Merkel's CDU at the German Federal elections in September 2013, the embarrassing failure of outgoing coalition partner FDP to gain over the 5 per cent threshold ${ }^{39}$ left the CDU starring down the barrel of a tricky coalition negotiation process. It became quickly clear that the only option for Merkel was to enter into a second 'grand coalition' with the rival centre-left SDP. When the coalition agreement was signed in December, the Social Democrats managed to win a strong range of concessions. Germany for the first time would adopt a federal minimum wage while labour laws would provide more income protection across sectors. Additionally, a modest public investment programme and

\footnotetext{
37 The Economist (May 30th, 2014), “The Euosceptic Union", available: http://www.economist.com/news/europe/21603034-impact-rise-anti-establishment-parties-europeand-abroad-eurosceptic-union ${ }^{38}$ Martin Banks (June 22nd, 2014), "Italy to push for 'United States of Europe' when it holds the EU presidency", available: http://www.telegraph.co.uk/news/worldnews/europe/eu/10918134/Italyto-push-for-United-States-of-Europe-when-it-holds-the-EU-presidency.html ${ }^{39}$ Euractiv (September 23rd, 2013), "Merkel triumphs as German liberals fall”, available: http://www.euractiv.com/eu-elections-2014/merkel-triumphs-liberals-get-pun-news-530623
} 
progressive pension reform would be implemented and, with the strength of the domestic economy, there were no plans for an austerity approach at home. ${ }^{40}$ While given credit for their domestic triumph, the SDP was criticised by many across Europe for failing to influence a more progressively-minded approach towards the Eurozone. Merkel and Wolfgang Schäuble ensured the policy on Europe would remain largely the same: the coalition agreement pointed the finger at other member states while demanding "structural reforms for more competitiveness and strict sustainable fiscal consolidation" ${ }^{41}$ While the SDP's fingerprints were evident in a section calling for the strengthening of Europe's social dimension, Social Europeans would have been frustrated by the lack of clear cut caveats to the existing ordoliberal strategy: where the language was promising, policy commitments to a new direction in Europe were completely lacking. Notably, Merkel and Schäuble had refused to yield on their rejection of Eurobonds and debt redemption. ${ }^{42}$

Following the agreement, many on the Left bemoaned what they felt would be a German status quo approach towards Europe. However, this sentiment underestimated the effect the shifting landscape in German politics could have on Europe. The Social Democrats had been heavily criticised during the previous Grand coalition for their lack of opposition to Merkel's austerity measures on the domestic front. This in turn significantly damaged their vote at the following election. ${ }^{43} \mathrm{~A}$ determination to not to suffer the same ignominy on this occasion has led SDP leaders to pursue an ambitious leftist agenda as a part of the coalition agreement. This has already spilled over into the language used on European policy and will continue to do so.

\footnotetext{
40 Wolfgang Munchau (December 1st, 2013), "Germany's coalition will have to break promises", available: http://www.ft.com/intl/cms/s/0/636c37fa-5866-11e3-9da600144feabdc0.html\#axzz37iCtgcTN

${ }^{41}$ Andrew Watt (November 29th, 2013), "Unintended Consequences: The Implications of The German Coalition Agreement for Europe", available: http://www.social-europe.eu/2013/11/germancoalition-agreement/

42 Wolfgang Munchau (December 1st, 2013), “Germany's coalition will have to break promises"

${ }^{43}$ Geir Moulson (September 22, 2013), "Germany's Merkel faces difficult coalition talks after 2 previous partners punished by voters", available: http://www.news1130.com/2013/09/22/merkeltriumphs-in-german-election-but-will-need-new-partner-as-coalition-ally-wiped-out/
} 
The Left in Germany has been lambasted over the years for choosing to side with the Christian Democrats ordoliberal orthodoxy over visions for European solidarity. ${ }^{44}$ In the few months since the coalition government took office, the SDP has already signalled that this will change. Vice Chancellor and Minister for Economic Affairs Sigmar Gabriel called for more flexibility over the tight rules surrounding budget deficit and debts in the Eurozone in June, while stressing the need for a greater focus on growth and jobs. ${ }^{45}$ Less than a week after his comments, Gabriel was in Paris to meet with centre-left European Prime Ministers to discuss European Parliament and Commission posts, as well as the Left's on-going strategy in Europe. ${ }^{46}$ His attendance was a clear sign that he stood with proponents of European solidarity and would not act as a lackey for Merkel.

When the Chancellor proclaimed in 2012 that there would be no Eurobonds "as long as I live", she did so in front of the most receptive audience possible in the form of the FDP, many of whom reportedly responded by saying, "we wish you a long life." 47 The fact is that should the debate in Europe shift further towards debt sharing and growth alternatives, pro-Eurobond Social Europeans now present in the coalition are likely to echo the pressure from the continent, and certainly unlikely to provide Merkel with a happy home for her austerity-centric strategy. While Gabriel's approach certainly risks drawing the ire of his 'bosses' Merkel and Schäuble, it will be lauded by the European Left and quite possibly come as welcome relief to the German electorate, which has for years been unable to tell the difference between CDU and SDP European policy. ${ }^{48}$ This will, at the very least, help to present a few forks in the road for the German debate on Europe in the coming years.

\footnotetext{
${ }^{44}$ Dyson, K (2008), "Germany: A Crisis of Leadership in the Euro Area", in The Euro at 10: Europeanization, Power and Convergence, page 140.

${ }^{45}$ Euractiv (June $\left.24^{\text {th }}, 2014\right)$, "Socialists back Juncker, want other jobs", available: http://www.euractiv.com/sections/eu-elections-2014/socialist-leaders-back-juncker-want-othertop-jobs-302977

46 Ibid.

${ }^{47}$ Spiegel online (June 27th, 2012), “The Coming EU Summit Clash: Merkel Vows `No Euro Bonds As Long As I Live'", available: http://www.spiegel.de/international/europe/chancellor-merkel-vowsno-euro-bonds-as-long-as-she-lives-a-841163.html

${ }_{48}$ EUobserver (June $\left.26^{\text {th }}, 2014\right)$, “The centre-left - acting like victors after the EU vote?" Available: http://euobserver.com/eu-elections/124720
} 


\section{2.ii Blocking the fringe: The establishment unites}

After the dust settled from the European elections, federalists of all colours were quick to ask for perspective and eager to provide context. In The New York Times only days after the same publication had reacted with alarm - an international business writer prudently reflected: "When can a vote of 25 per cent be described as a 'stunning victory' or even a 'political earthquake'?" ${ }^{49}$ Almost immediately following the vote the dominant factions in European politics began plotting ways to alienate the growing fringe. This is not likely to be a particularly difficult task in the European Parliament with law-making only marginally affected, if at all, by the increase in Eurosceptic MEPs. ${ }^{50}$ The lack of threat to the federalist, compromisehappy Parliament has been outlined by French think-tank Notre Europe, which noted that "70 per cent of decisions are done via deals between the three main groups", with the EPP, S\&D and ALDE all refusing to work with Eurosceptic MEPs. ${ }^{51}$

The Eurosceptic vision has been dealt a further blow by the confirmation of JeanClaude Juncker as Commission President six weeks following the elections. This is a particularly damaging outcome for David Cameron who had fought to block his selection, citing an undemocratic nomination process and a rejection of the Luxembourgian's plans for Europe. The Prime Minister and Eurosceptic Tories had latched onto labels of Juncker as an "arch-federalist" political fixer"52 and "Brussels insider" whom they claimed was exactly the wrong type of figure to reform the EU. ${ }^{53}$ However, Cameron failed to convince fellow EU leaders - including centre-

\footnotetext{
${ }^{49}$ Anatole Kaletsky (May 30th, 2014), "Reflecting on European Election Lessons", available: http://www.nytimes.com/2014/05/30/business/international/reflecting-on-european-electionlessons.html?_r=2

${ }^{50}$ Euractiv $\left(28^{\text {th }}\right.$ May, 2014), "Eurosceptic MEPs will have 'marginal' influence in EU Parliament", available: http://www.euractiv.com/sections/eu-elections-2014/eurosceptic-meps-will-havemarginal-influence-eu-parliament-302482

51 Ibid.

52 Nicholas Watt (June 9th , 2014), "David Cameron steps up campaign to block Juncker appointment", available: http://www.theguardian.com/politics/2014/jun/09/labour-tories-lib-dems-block-juncker ${ }^{53}$ Nicholas Watt and Ian Traynor (June 27th 2014), "Cameron tells EU it may live to regret JeanClaude Juncker appointment", available: http://www.theguardian.com/world/2014/jun/27/davidcameron-eu-jean-claude-juncker
} 
right Eurosceptic allies in Sweden and the Netherlands - to look elsewhere and could not enforce a 'blocking minority' in the Council against Juncker. ${ }^{54}$

A European grand coalition has very much been forming in Brussels and most of the talk regarding deals in the Parliament and the Commission have been from the left and right of centre, while disjointed Eurosceptic parties struggle to come together. Juncker received a comfortable majority of votes in the EP to become Commission President, while the Socialists managed to secure the posts of Economics Commissioner and President of the Parliament as part of the cross-party agreement. ${ }^{55}$ Meanwhile, anti-EU parties have had a harder time finding common ground, an unsurprising development due to the vast array of ideological underpinnings at play between anti-federalist groups. Nigel Farage led the negotiations to form a 48-MEP strong EFDD group, not without its share of idiosyncrasies. Aside from its 24 UKIP members, the group consists of $17 \mathrm{MEPs}$ representing the Italian Five Star Movement, led by comedian Beppe Grillo, alongside two Swedish Democrats (a party with a racist history linked to Nazi groups); an MEP seeking more EU subsidies for Latvian farmers; an aerobatic champion former mayor from Lithuania with alleged links to Russian crime; and a 64-year-old Front National MEP who defected from the French party due to its racist policies. ${ }^{56}$

While Farage is expected to have difficulty with the veritable motley crew that make up the delegations of the EFDD, the UKIP leader managed to achieve more than Marine le Pen. In a bizarre round-robin of accusations between a number of pots and kettles, the Eurosceptic blame game designed to publically out 'the most extreme' took centre-stage. UKIP refused to join up with Front National - which it labelled too right-wing - while in turn the French nationalists were unable to meet the requirements to form a Parliamentary group, after anti-immigrant Dutch MEP Geert Wilders refused to form a coalition with Polish Eurosceptics who supported the

\footnotetext{
54 Ibid.

55 Valentina Pop (July $8^{\text {th }}$, 2014), “Juncker: Economics commissioner will be a Socialist", available: http://euobserver.com/institutional/124898

${ }^{6}$ Nikolaj Neilsen et al. (June $6^{\text {th }}$, 2014), "British eurosceptic cobbles together EP group", available: http://euobserver.com/eu-elections/124667
} 
abolition of women's voting rights. ${ }^{57}$ The failure of Eurosceptics to unite over anything resembling a single cause while airing their pronounced disagreements in public has put a dent in the side of the movement. While supporters of the vision for less Europe in the predominantly soft Eurosceptic ECR have formed much more of a united front against the 'overreach of Brussels', they will struggle to remain unblemished by their louder and far more dysfunctional 'allies' to the right.

While it is too early for academic analysis, a number of commentators have come to the conclusion that the Eurosceptic wave could well work as a blessing in disguise for the federalist establishment. British PR firm MHP said, "It would be a mistake to paint the 2014 elections as a devastating blow for the European project." 58 Instead, it believed the results would lead to "'more Europe' and eye-catching initiatives to show tangible benefits to European citizens."59 The Eurosceptic think-tank Open Europe reluctantly agreed. Director Mats Persson said that while European politics may become more unpredictable, the anti-European surge would "paradoxically... strengthen the resolve of the three mainstream groups to continue to vote for more Europe in the European Parliament, in order to freeze out the anti-EU contingent." Iain Begg of the London School of Economics felt that Eurosceptics would likely be frustrated by most of the recent and prospective initiatives for reform such as debt mutualisation and macroeconomic stability based on further integration. ${ }^{60}$ He also argued that the results could well spur federalists on, forcing the realisation "that the procrastination and squabbling over second-order concerns cannot continue and that all the institutions need to look for more comprehensive and coherent solutions". ${ }^{61}$

\footnotetext{
${ }^{57}$ Nikolaj Neilsen (June 24 $\left.4^{\text {th }}, 2014\right)$, “Le Pen fails to create far-right EP faction”, available: http://euobserver.com/eu-elections/124719 58 MHP Communications (26th May, 2014), "European Parliament Elections 2014: Outcomes, Trends, Implications", available: http://mhpccom.wpengine.netdna-cdn.com/brussels/files/2014/05/MHPEuropean-Elections-2014-Report.pdf 59 Ibid. ${ }^{60}$ Open Europe (May 26 $6^{\text {th }}$,2014), "Anti-EU and protest parties across Europe on course to win almost a third of all seats in new European Parliament" ${ }^{61}$ Iain Begg (May 26th 2014$)$, “European Parliament Election results - our experts react", available: http://blogs.lse.ac.uk/europpblog/2014/05/26/european-parliament-election-results-our-expertsreact/
} 


\section{2.iii Where lies the soul of Europe?}

Two months on from the European elections, cooler heads generally prevail in the analysis of the event. However, depending on who one listens to, the result is still being classified as a wake-up call, a turning-point in European politics or a cataclysmic eruption of public unrest. Chapters 2 and 3 in this thesis analysed European policy-makers' reactions to the crisis through the reform of economic governance. This chapter has examined an election which acted as a report card on their efforts. The markers were not kind: David Cameron was correct in surmising that tens of millions of voters had decided to "give their governments a kicking" .62So what for the future of Europe and the political visions that will influence its direction?

a) Separate nations, separate souls

Eurosceptics will argue that this is only likely to be the beginning. They may be right. The voters' response to being afforded their European scorecards at first glance appeared to mark a big red cross against 'more Europe'. This chapter has pointed out flaws in the pro-nationalist/anti-federalist explanations for the rise in Euroscepticism. It has also placed a level of perspective on its real political implications. However, Farage and his friends have certainly put a brighter spotlight onto the European project and there is a chance to make the inevitable become not so inevitable.

Supporters of the vision for less Europe will hope the cluster of ideologues is able to make enough noise in the European Parliament not to render Euroscepticism obsolete in Brussels. However, the crucial battle grounds will lie in the member states. Local and national elections will provide the opportunity not only to spread the message at a more grass-roots level with greater voter turnout, but also afford Eurosceptics the chance to put pressure on mainstream parties to adapt to their populist policy positions. In many cases, small influence may be enough: where UKIP and Tory Eurosceptics have forced the British Conservative Party leadership to

${ }^{62}$ Anatole Kaletsky (May 30th, 2014), “Reflecting on European Election Lessons" 
wrestle with the idea of withdrawal from the EU, they have come close with opposition leader Ed Miliband. The Labour candidate for Prime Minister in 2015 has come under pressure from a number of his caucus to match David Cameron's promise of a referendum following the UKIP's election boil over. ${ }^{63}$

Other areas of focus for Eurosceptics on the continent include Denmark following the strong election showing, Sweden and Spain where there are upcoming national elections, and especially France, where nationalists will be desperate to take advantage of their extremely successful campaign and indeed appear in a strong position to influence European policy in France. With France's position as one of the two central drivers of integration throughout history, the influence of the Front National genuinely threatens to affect the course of Europe's future.

A repatriation of powers from Brussels is unlikely should the EU suddenly find its feet, and regain its long-lost respect from the public. While this chapter has argued that a grand coalition between the established parties in the European Parliament could act as a positive, this convergence could also potentially work for Eurosceptics. Should EU policy-makers resort to a series of lowest-commondenominator compromises on major issues of reform, they will most likely continue to appear out of touch and will set themselves up to be punished by the voters. ${ }^{64}$ The danger of coming together lies in the perception to the electorate that there is no major difference between the major players, an assessment which will not act as an advantage should the European economy continue to flounder and other issues remain unresolved.

Despite the best efforts of hard Eurosceptics, a breakup of the union is not on the cards. The biggest potential shakeup to the EU membership on the horizon is in the chance of UK exit in 2017. However, while certainly a possibility, it would at present

\footnotetext{
${ }^{63}$ Nicholas Watt (July 2nd, 2014), "Miliband under pressure to match Tories EU referendum pledge", available: http://www.theguardian.com/politics/2014/jul/02/miliband-pressure-match-tories-eureferendum-pledge 64 MHP Communications (26th May, 2014), “European Parliament Elections 2014: Outcomes, Trends, Implications"
} 
appear unlikely, with the Conservatives slightly behind in the polls to Labour65, and the near certainty that David Cameron will put considerable effort into the 'yes' campaign should he win another five years as Prime Minister. ${ }^{66}$ In terms of the broader Eurosceptic vision which wishes to retain the EU but opposes moves towards an ever closer union, the jury is still out on the new Commission, but support is weak in the Parliament and Council. Cameron may gain some concessions in renegotiation that he can sell to his domestic audience, but the governments of Finland, Hungary and the Netherlands will be relatively powerless to stop further integration. Meanwhile, the Swedish Prime Minister will first have to cling onto his position, which looks under threat from his Europhile Social Democratic opponent ahead of the national election in September 2014.

b) How Social Europe will prosper

Patience must be the virtue for the European Left, as the future looks brighter than at first glance. A number of developments would represent a victory for Social Europeans in the coming years: The adoption of Eurobonds, the creation of a substantial growth fund, a revision of the SGP, the creation of a Eurozone budget, a fiscal and transfer union, a re-focus on the social dimension. While all of these will not be achieved, and a full re-distributive United States of Europe remains beyond the wildest dreams of European socialists, some of these measures are distinct possibilities in the short-medium term. The most important facet of reform for the Left must be the removal of austerity as the weapon of choice for Europe's economic woes, and this is certainly on the cards in the EU in 2014.

Three factors have set the Social European vision up as the most distinct benefactor of recent political shifts in the EU. First of all, Brussels finds itself in the greatest 'must act' situation since the near default of Greece in the heart of the crisis. Not only are EU institutions being forced to fight a still faltering economy, but also a

\footnotetext{
65 Jim Pickard (July 7th, 2014), “UK's Labour leads Conservatives in latest opinion polls", available: http://www.ft.com/intl/cms/s/0/1db41af8-05f8-11e4-89a5-00144feab7de.html\#axzz37tHjilut ${ }_{66}$ Benjamin Russel (November $4^{\text {th }}$, 2013), "David Cameron: I can secure yes vote in EU referendum", available: http://www.express.co.uk/news/uk/441084/David-Cameron-I-can-secure-yes-vote-inEU-referendum
} 
disillusioned voter base and a Parliamentary fringe that wishes to pull it apart from within. The Eurozone must find an alternate vehicle to austerity to mend its woes: while the German economy has prospered in recent times, most others in the single currency are still struggling. The tiny economy of Luxembourg is the only other in surplus in the Eurozone, while only five of eighteen are currently adhering to both the debt and deficit requirements of the SGP. ${ }^{67}$ Moreover, calls for Germany to address its huge current account surplus, by pulling some of its exports from the periphery are increasing in volume and sincerity. ${ }^{68}$ The existing reforms to economic governance, while significant, have been based on a one-track tactic of consolidation and - regardless of arguments over economic ideology - it is an approach which has simply failed to deliver the desired results while becoming ever more unpopular among the public. ${ }^{69}$

Secondly, the Left finally finds itself in a favourable position to pull together its influence and act. Chapter 3 explored the shift in the political tide following Francois Hollande's election in 2012 and the slowly eroding support base for the German-led consolidation model. The scene following the elections, while somewhat complicated by the Eurosceptic rise, shows little to dissuade the Left. Whereas in 2009, a new European Parliament came to power met by Council laden with centre-right strength, the same cannot be said in 2014. Eight of the 18 Eurozone heads of state currently sit on the left, while an emphasis on greater solidarity is also supported by the leaders of Greece, Ireland, Spain and Cyprus inside the Euro Area and the leaders of Malta, the Czech Republic and Denmark ${ }^{70}$ outside of the single

\footnotetext{
67 "Economic indicators - Europe", available: http://tradingeconomics.com/, (accessed: July 19th, 2014).

${ }^{68}$ Euractiv (March 7th 2013), "Brussels renews criticism of German trade surplus", available: http://www.euractiv.com/sections/euro-finance/brussels-renews-criticism-german-trade-surplus$\underline{300733}$

${ }^{69}$ Euronews (October 2nd, 2013), "Half of Europeans say austerity has failed: Gallup poll”, available: http://www.euronews.com/2013/10/02/half-of-europeans-say-austerity-has-failed-gallup-poll/

${ }^{70}$ Denmark's pro-European Prime Minister Helle Thorning Schmidt has expressed her desire for Denmark to join the euro in the near future. Source: EurActiv (February 21st, 2014), “Danish PM says country 'should' join the euro", available: http://www.euractiv.com/euro-finance/danish-pmcountry-join-euro-news-533661
} 
currency. ${ }^{71} \mathrm{~A}$ good deal of hope is being placed on Italian newcomer Matteo Renzi. The 39-year-old centre-left Prime Minister has stormed into Rome with a pledge to rid the political establishment of corruption and restore the Italian economy. ${ }^{72} \mathrm{With}$ Italy taking over the Council presidency for the second half of 2014, Renzi will be hoping to exploit his strong standing to push the EU towards adopting less austerity-focused budget rules and a more collective approach to reform centred on the social model. ${ }^{73}$ Renzi's rise has been a particularly timely one for Social Europeans in search of an idol, as Francois Hollande's domestic popularity and his influence on Europe as a result has continued to decline to unprecedented levels. ${ }^{74}$

The other figure of great importance for Social Europeans is Jean-Claude Juncker. While hailing from the EPP, the experienced Luxembourgian politician has become known for his slightly more centre-left view on European integration and economic reform. ${ }^{75}$ Never having set out his own doctrine of integration during his time in Brussels, Juncker sent a message in his opening address as President by demanding a more political Commission and praising the "patient, courageous and determined" work of the founding fathers of European federalism in Jacques Delors, Francois Mitterrand and Helmut Kohl. ${ }^{76}$ Juncker further disassociated himself from the outgoing commission - often accused of bowing to German demands over austerity - by placing a heavy emphasis on social issues pledging to "revive the community method" and arguing that "you can't achieve competitiveness by getting rid of social security... the internal market is not more important than social affairs."77 Known as

\footnotetext{
${ }^{71}$ Valentina Pop (June 23rd, 2014), "Centre-right to strike deal with centre-left on Juncker, Schulz", available: http://euobserver.com/eu-elections/124688

72 EurActiv (June $11^{\text {th }}, 2014$ ), "Italy to launch public administration reforms", available: http://www.euractiv.com/sections/jobs-and-growth/italy-launch-public-administration-reforms$\underline{302727}$

${ }_{73}$ Alvise Armelini (June 20 th, 2014), “Can Italy's 'political serial killer' change EU course on austerity?", available: http://euobserver.com/eu-elections/124670

${ }^{74}$ Hugh Carnegy (April 13th 2014), "Francois Hollande's approval rating falls despite reshuffle", available: http://www.ft.com/intl/cms/s/0/9338f082-c2e1-11e3-b6b5-

00144feabdc0.html\#axzz38jcnE19d

${ }^{75}$ Luke Baker (June 13 $\left.3^{\text {th }}, 2014\right)$, “Jean-Claude Juncker - Federalist danger man or skilled fixer?", available: http://uk.reuters.com/article/2014/06/13/uk-eu-commission-juncker-insightidUKKBNOEO0GB20140613

${ }_{76}$ Honor Mahony (July 15th, 2014), “Juncker elected: promises more social EU, more political commission", available: http://euobserver.com/political/124980

77 Ibid.
} 
supporter of debt mutualisation, having himself presented a plan for Eurobonds in 2010, Juncker will be expected, at the very least, not to sit through three years of economic hardship before realising the need for a different economic direction in the Eurozone. Moreover, he arrives at a time where the European Parliament essentially managed to select its own the Commission President which, while under controversial circumstances, displayed the greatest shift in the balance of power away from the Council in European history. With a full backing from the vast majority of EU leaders, ${ }^{78}$ Juncker has a strong mandate to act and will feel the necessity to make bold moves, so as to alleviate the pressure from the fringes and disaffected public.

Optimistic advocates for reform on the European Left will no doubt also argue that they have already benefitted from closer cooperation with pro-austerity forces in the Council, Commission and Parliament. In recent months, European policy-makers have completed a landmark agreement on the formation of a banking union ${ }^{79}$, have worked towards the implementation of a financial transactions $\operatorname{tax}^{80}$ and have found common ground on the potential creation of a Eurozone parliament. ${ }^{81}$ This pattern of federalist reform not only underscores the commitment to 'more Europe' but also leaves the impression that moves towards increased economic solidarity may not be too far away.

\footnotetext{
${ }^{78}$ Daily Sabah (July 16"th 2014), “Juncker to head EU bloc's executive arm - confirmed by European Parliament", available: http://www.dailysabah.com/europe/2014/07/16/juncker-to-head-eu-blocsexecutive-arm-confirmed-by-european-parliament

${ }^{79}$ European Commission (April 15 th 2014), "Finalising the Banking Union: European Parliament backs Commission's Proposals", Press Release, Brussels, available: http://europa.eu/rapid/pressrelease STATEMENT-14-119_en.htm

80 Alex Barker (May 6 ${ }^{\text {th }}, 2014$ ), "Eurozone divided over financial transaction tax deal", available: http://www.ft.com/intl/cms/s/0/d8a5d630-d529-11e3-9187-

00144feabdc0.html?siteedition=intl\#axzz38jcnE19d

81 EurActiv (February $5^{\text {th }}, 2014$ ), “UK Conservatives balk at plans for eurozone parliament", available: http://www.euractiv.com/uk-europe/uk-conservatives-balk-plans-euro-news-533273
} 
c) Protecting the stability union

The argument for a status quo austerity-centric approach to EU integration lies in the age-old belief that - regardless of the surrounding circumstances - Europe's future comes down to Germany. While simplistic and somewhat overstated, like many clichés it has a strong element of truth to it. If Merkel and Germany continue to insist, it may be able to withstand the pressure for reform to keep the ordoliberal orthodoxy in place. However, while the loss of friends in Europe will not bother the German government to a great degree at the moment, an angry tide of antiEuropean fervour will. Responding to an increase in support for anti-euro AFD prior to the German election, government ministers said giving up the euro would be "economically insane" and would mean "risking the collapse of Europe". 82 The only steady way forward for the vision of Europe under the consolidation coalition, is via a vast improvement for the Eurozone economy in the coming months and years. If there are few signs of the economy soon springing into life, imbalances being redressed and public disorder being tamed, Merkel - the pragmatist who happily accepted the bulk of the SDP's leftist agenda to revert to stability in Germany ${ }^{83}$ - will likely be forced to seek a compromise that alters the political and economic nature of the union in favour of the European Left. The likelihood of a steadfast refusal to this end depends on perhaps the most crucial question of them all. Faced with the dilemma of protecting only one of its two post-war national orders, which way will it go?

\footnotetext{
82 EUbusiness (28 th April, 2013), "Schäuble says anti-euro call 'economically insane'”, available: http://www.eubusiness.com/news-eu/finance-economy.oad ${ }^{83}$ Spiegel online (April 9th 2012 ), "Wooing the Workers: Merkel Shifting Left to Boost Re-Election Chances", available: http://www.spiegel.de/international/germany/german-political-analysis-ofleftward-shift-by-chancellor-angela-merkel-a-826387.html
} 


\subsection{Conclusion}

This chapter has discussed the recent rise of Euroscepticism and its impact on the 2014 elections. It has found that while there are a number of explanations for the spike in anti-European sentiment, including concerns over loss of national identity and feelings of a 'democratic deficit', the surge in frustration with the EU is primarily linked to economic dissatisfaction and an increasing lack of trust in EU institutions as they failed to substantially mitigate the effects of the crisis. Here this thesis has sought to look past the alarmist assumptions made by commentators immediately following the electoral results, and restored a sense of perspective to the analysis. While European leaders are aware of the mood for change, the Eurosceptic rise will most likely have the paradoxical effect of forcing the two dominant visions into compromise and setting the scene for more Europe, and not less. This is unlikely to work via the status quo approach advocated by Germany and its allies, with the consolidation coalition faced with a tough choice over embracing further solidarity if it is to restore public faith in the European project.

The ordoliberal commitment to sound public finances, fiscal consolidation and stateminded markets has worked for the German economy. Moreover, it has proved domestically popular to the extent where it is almost embedded within the nation's culture. Meanwhile, the pursuit of peace and solidarity within the "fundamental rightness" of the European project has played at least an equal part in its recent history. Eurosceptics and many outside observers believe the crisis has exposed an impossible relationship between nations fraught with the problems caused by competing cultures. The Germans do not agree, nor have they ever. Angela Merkel rose to prominence in German politics as a protégé of Chancellor Helmut Kohl. The great statesman, who referred to Merkel as "my girl", was chief among the designers of the euro, a man who dreamed of the United States of Europe and believed the Union was a matter of heart and soul. ${ }^{84}$ Lewis saw Germany's adoption of the euro

\footnotetext{
${ }^{84}$ Imke Henkel (June 24 $\left.4^{\text {th }}, 2014\right)$, “David Cameron's increasingly strong opposition to Jean-Claude Juncker runs the risk of alienating Angela Merkel", available: http://blogs.lse.ac.uk/politicsandpolicy/david-camerons-increasingly-strong-opposition-to-jeanclaude-juncker-runs-the-risk-of-alienating-angela-merkel/
} 
in the 1990s as "a device for flushing away the past", but this obscures the true meaning of the move towards the single currency. The Deutsch mark was supremely popular 85 , and its abolition contributed significantly to the end of Kohl's chancellorship in 1998. ${ }^{86}$ The creation of the single currency represented a sacrifice for Kohl and Germany in the name of European unity. "Germany is our fatherland; Europe is our future", said Kohl. At a time when the European project has come under its strictest scrutiny since the Maastricht Treaty and austerity has failed to deliver, it is easy to imagine Merkel's mentor's words ringing in her ears, and she may yet make her own sacrifice. Germany's future is Europe. A future for Europe must mean change.

${ }^{85}$ Dyson, K (2008), “Germany: A Crisis of Leadership in the Euro Area”, page 158.

86 EurActiv (July 18 th, 2014), "Kohl encourages Merkel to pursue EU unity", available:

http://www.euractiv.com/sections/euro-finance/kohl-encourages-merkel-pursue-eu-unity-303579 


\section{Conclusion}

This thesis has traced the changing appeal of three visions for Europe during the Sovereign Debt Crisis period of 2010-2014. It has done so by looking at three separate rounds of debate: the economic governance reform process encompassing both the creation of the Fiscal compact and the Two-pack, as well as the European elections of May 2014. The vision of Germany and its allies promoting a more deeply integrated stability union has for the most part dominated the Eurozone crisis period. Through nearly all the major and minor reforms to economic governance in the EU, the emphasis on controlling deficits and debt institutionalised by the Stability and Growth Pact has been not only preserved, but enhanced. However, a shift in the political climate in 2012 and the effects of a rise in anti-European sentiment on the 2014 elections have called into question the federalist ordoliberal status-quo. This thesis has argued that it is not the Eurosceptic, but the Social European vision which has gained the most momentum from the changing political tide in the Union over the past two years, and is best set to prosper as the continent emerges from the crisis.

The success of the consolidation coalition in embedding its vision for Europe over the reform period had much to do with institutional control. While there was undoubtedly friction over the austerity-first approach to solving the Eurozone's economic woes in the early months of the crisis, the fact that this vision was so strongly held by the most influential political actors remained the difference. The consolidation bias was heavily swayed by the Merkozy pact and robust initial support in Brussels. The philosophical familiarity between Angela Merkel and Nicholas Sarkozy allowed the pair to set a common strategy prior to crucial negotiations over governance reform in the EU. Moreover, the collective position held by European political heavyweights Mario Draghi, José Manuel Barroso and Herman Van Rompuy was one that stressed the need for a firming of fiscal rules and budgetary discipline as the most essential elements towards restoring the integrity of the EMU. Despite the pain caused by enforced austerity measures on the people of the PIIGS nations, it had become difficult for austerity opponents to argue against the edict handed down from Berlin and Brussels. The consolidation coalition was, to 
a large extent, able to successfully circulate the view that the Eurozone's imbalances had been caused by profligate spending and poor fiscal management on the part of the crisis countries.

Prior to Francois Hollande's victory in May 2012, the crisis period represented a turbulent time for the European Left. Outnumbered by centre-right governments in the Council and hamstrung by the sheer power of pro-austerity voices, Social Europeans struggled to promote their vision for full economic and political integration in the EU. The passing of the Fiscal compact derided by many as the foundations of an 'austerity union' represented a clear loss for the Left. As argued in Chapter 2, those seeking an alternative to the status quo response to the crisis did not have time on their side. The failure to renegotiate not only showed up the European Left's material weakness but also revealed the fear held by many member states of alienation from Europe's central brokers in Brussels and Berlin and marginalisation from the decision-making process.

This fear began to quickly subside with the end of the Merkozy pact. The everincreasing support for the implementation of a Eurobonds scheme was indicative of the shifting political climate in Europe. Since this time, leaders have been looking more and more for alternative measures to tackle the crisis and have become critical of responses that focus wholly on fiscal rectitude. The increased scrutiny over the ordoliberal status quo however has not simply been a story about France and Germany. A shift in attention from stability to solidarity was put in play by Hollande's ascension to the head of French politics, but was more than helped by a change in tune across European institutions in Brussels. Where Draghi, Barroso and Van Rompuy had all strongly endorsed austerity, they were now looking to reconcile fiscal discipline with provisions for growth and plans for public investment. To Germany's chagrin the consolidation coalition has dwindled in size since the crisis reform period's turning point. Equally instrumental in the revival of the Social European vision has been a realisation of the failure of austerity measures to spark anything close to the economic recovery so desperately needed in the Eurozone, as discussed in Chapter 4 . The crisis period has provided four years of 
pain for disenfranchised Europeans and has thus served to act as a learning episode for the failings of the consolidation-centric approach to recovery.

The most telling outcome of this period in Europe's history has been the reinforcement of an unwavering commitment towards further European integration. This development has hurt the Eurosceptic vision with more Europe appearing increasingly inevitable. Some will argue against this position and point to uncertainty over the lasting effects of the Eurosceptic rise in the 2014 elections. Why should advocates of 'less Europe' not be able to latch onto uncertainty over the European project in the same way opponents to austerity have been able to push the conversation on economic reform away from an obsession over balanced budgets and fiscal sanctions? The greatest chance for Eurosceptics will initially be at national, and not the European level. Forthcoming elections in The UK, Sweden and Spain will provide the opportunity for anti-EU parties to exploit public antipathy towards Brussels and perhaps more importantly, upset the status quo by forcing mainstream parties to court the Eurosceptic vote. It would be foolish to brand the success of nationalist parties at the elections as a flash in the pan, as these movements certainly unearthed a deeper-lying concern over a declining trust in EU institutions. However, the inability of Eurosceptic parties to form any sort of coherent coalition of ideas across the continent - as indicated by the idiosyncratic groupings in the European Parliament - showed just how weak the anti-establishment movement remains relative to the political actors representing the two federalist visions.

The explanations offered in this thesis for the changing political landscape in Europe throw up a number of interesting questions about how politics is made in the EU. The primary purpose of this work has been to uncover the political soul of Europe by analysing the contrasting fortunes of the three competing visions over the crisis period, and while it is beyond the scope of this thesis to wade into the contested debate over the location of power in EU policy-making, it is a discussion which 
could help to illuminate some of the conclusions found here. This debate has been best captured in more recent years by the likes of Moravcsik, Hix ${ }^{1}$ and Richardson. ${ }^{2}$

This thesis does not take a position on which is the more accurate theoretical understanding of the political process in Europe. However, the author broadly agrees with the evaluation offered by Hix, which holds sympathy Moravcsik's analysis of Germany and France as the traditional drivers of integration and the two key players in the series of grand bargains, but notes the inability of intergovernmental theory to explain "the more complex environment of day-to-day legislative politics in the EU". ${ }^{3}$ The period in European politics covered by this thesis provides an interesting case study for this existing debate and is certainly worthy of further examination. This is especially the case due to the crisis-response nature of economic policy-making in Europe over the past four years. The processes by which policy is made in the EU during normal economic cycles have almost undoubtedly been altered in the crisis period and it would be interesting to discover how traditional explanations of EU politics can attest to these changes.

This thesis has concluded that the overarching commitment to more Europe held by the political establishment in the EU has proved to be too big of a barrier for supporters of the Eurosceptic vision to overcome. This is likely to continue to be the case. In fact, moves towards a more complete federalism are more on the cards than they were before the global economy took a disastrous turn for the sores in 2008 . Furthermore, it has been argued here that the unlikely alliance of pro-EU forces created to oppose the Eurosceptic rise should more heavily benefit the Social European vision than those who make up the consolidation coalition. So what does this mean for Europe's future? The momentum gained by the Left prior to the May 2014 elections will not have been significantly disrupted by the outcome. Rather, calls for alternatives to the existing austerity-centric approach to reform have gained more credence, with the integrity of the European project in its current guise under

\footnotetext{
${ }^{1}$ Hix, S. (2011), The Political System of the European Union, Palgrave Macmillan, Basingstoke, UK.

${ }^{2}$ Richardson, J (2005) European Union: power and policy-making, Routledge, NY.

${ }^{3}$ Hix, S. (2011), The Political System of the European Union, Palgrave Macmillan, Basingstoke, UK, page 18.
} 
threat. Onlookers should not expect a denouncement of the rules which make up the consolidation-based EMU, nor should they dream of Berlin and Brussels embracing anything resembling a truly socialist Union. There is enough support within the Union to maintain the ordoliberal orthodoxy's commitment to sound money and strong public finances to a considerable degree. However, in order to protect the whole, Germany and its allies will most likely call for a compromise which repairs the social dimension and re-establishes European solidarity as the Union moves ever closer towards a more complete federation of nation states. 


\section{Bibliography}

\section{Print/ hard-copy sources:}

Archer, C. (2008), The European Union, Routledge, Oxfordshire

Berglund, S. et al (2006), The Making of the European Union: Foundations, Institutions and Future Theories, Edward Elgar Publishing, Cheltenham

Buller, J. and Gamble, A. (2008), "Britain: The Political Economy of Retrenchment", in: Dyson, K. (ed) The Euro at 10: Europeanization, Power and Convergence, Oxford University Press, UK, pp.258-273

Caporaso, J.A. and Kim, M. (2012), “The Maastricht Treaty at Twenty: A GrecoEuropean Tragedy?" In: Christiansen, T. and Duke, S. (eds.) Journal of European Integration, Vol. 34, no. 7, Routledge, London, pp.769-789

Christiansen, T. et al (2012) "Understanding and assessing the Maastricht Treaty", in: Christiansen, T. and Duke, S. (eds.) Journal of European Integration, Vol. 34, no. 7, Routledge, London, pp.685-698

Dyson, K (2008), “Germany: A Crisis of Leadership in the Euro Area”, in: Dyson, K. (ed) The Euro at 10: Europeanization, Power and Convergence, Oxford University Press, UK, pp.132-164

Dyson, K. (2012), "Maastricht Plus: Managing the Logic of Inherent Imperfections", in: Christiansen, T. and Duke, S. (eds.) Journal of European Integration, Vol. 34, no. 7, Routledge, London, pp.791-808

Featherstone, K. (2011), “The Greek Sovereign Debt Crisis and EMU: A Failing State in a Skewed Regime" in: Cini, M. et al (ed) Journal of Common Market Studies Volume 49, issue 2, UACES, pp.193-217

Feldstein, M. (1997) "EMU and International Conflict", in Foreign Affairs, Vol. 76, no. 6, Council on Foreign Relations, USA, pp.60-73 
Fouarge, D. (2004), Poverty and Subsidiarity in Europe: Minimum Protection from an Economic Perspective, Edward Elgar Publishing, Cheltenham

Gillingham, J. (2003) European Integration 1950-2003: Superstate or New Market Economy? Cambridge University Press, NY

Gray, T. and Wilke, S. (1996), German Unification and its Discontents: Documents from the Peaceful Revolution, University of Washington Press, USA

Harmsen, R. and Spiering, M. (2005), Euroscepticism: Party Politics, National Identity, and European Integration, Rodopi Publishing, Amsterdam

Hemerijck, A. (2002), “The Self-Transformation of the European Social Model(s)”, in: Esping, Andersen, G (ed) Why We Need a New Welfare State, Oxford University Press, UK, pp.172-214

Hix, S. (2011), The Political System of the European Union, Palgrave Macmillan, Basingstoke

Hooghe, L. and Marks, G. (2007), “Sources of Euroscepticism”, in: Aarts, K. et al (ed) Acta Politics, Volume 42, Palgrave Macmillan, The Netherlands, pp.119-127

Jospin, L. (2002) My Vision of Europe and Globalization, Policy Network, London Leconte, C. (2010), Understanding Euroscepticism, Palgrave Macmillan, Hampshire Lewis, M. (2011), Boomerang: The Biggest Bust, Penguin Books, London Liddle, R. (2008), “Is this the death of social democracy in Europe?" In: Lodge, G. et al (ed) Public policy research, Volume 15, Issue 3, pp.111-113

Marsh, D. (2011), The Euro: The Battle for the New Global Currency, Yale University Press, Connecticut

McGowan, F. (2001), “Social Democracy and the European Union”, in: Mertell, L. (ed) Social Democracy: Global and National Perspectives, Palgrave, NY 
McKay, D. (1999), Federalism and European Union: A Political Economy Perspective, Oxford University Press, UK

McNally, D. (2011), Global Slump - The Economics and Politics of Crisis and Resistance, Spectre Publishing, Oakland

Molle, W. (1997), The Economics of European Integration: Theory, Practice, Policy, Ashgate Publishing, Aldershot

Moravcsik, A. (1998), The Choice for Europe: Social Purpose and State Power from Messina to Maastricht, Cornell University Press, NY

Reid, T.R. (2004), The United States of Europe, Penguin, NY

Richardson, J. (2005), “Policy-making in the EU: interests, ideas and garbage cans of primeval soup", in: Richardson, J (ed) European Union: power and policy-making, Routledge, NY

Rupnik, J (2006), “The European Union's Enlargement to the East and Solidarity”, in: Michalski, K. (ed) What hold Europe together? Central European University Press, Budapest, pp. 86-92

Sapir, A. (2006), "Globalization and the Reform of European Social Models”, in: Cini, M. et al (ed) Journal of Common Market Studies, Volume 44, issue 2, Blackwell Publishing, Oxford, pp.369-390

Serrichio, F. et al (2013), "Euroscepticism and the global financial crisis", in Journal of Common Market Studies, Volume 51, issue 1, Blackwell Publishing, Oxford, pp.51-64

Startin, N and Krouwell, A. (2013), “Euroscepticism Re-galvanised: The Consequences of the 2005 French and Dutch Rejections of the EU Constitution", in: Cini, M. et al (ed) Journal of Common Market Studies, Volume 51, issue 1, Blackwell Publishing, Oxford

Taylor-Gooby, P. et al (2000), European Welfare Futures: Towards a Theory of Retrenchment, Polity Press and Blackwell Publishing, Cambridge 
Taylor-Gooby, P. and Larsen, Trine P. (2004), “New Risks at the EU Level; A Spillover from Open Market Policies?" In: Taylor-Gooby, P. (ed) New Risks, New Welfare: The Transformation of the European Welfare State, Oxford University Press, UK, pp.181-205

Umbach, G. and Wessels, W. (2008), “The Changing European Context of Economic and Monetary Union: 'Deepening', 'Widening', and Stability', in: Dyson, K. (ed) The Euro at 10: Europeanization, Power and Convergence, Oxford University Press, UK, pp.54-68

Van Oudenaren, J. (2004), “The European Union: From Community to Constitution”, in: Tiersky, R. (ed) Europe Today: National Politics, European Integration and European Security, Rowman and Littlefield Publishers, Maryland, pp.21-58

Verhelst, S (2011), The Reform of European Economic Governance: Towards a Sustainable Monetary Union? Academia Press, Gent

Vasilopoulou, S. (2013), “Continuity and change in the study of Euroscepticim: Plus ca change?" in: Cini, M. et al (ed) Journal of Common Market Studies, Volume 51, issue 1, Blackwell Publishing, Oxford, pp.153-168

Walsh, H. A. (2004), “Unified Germany: The Desire for Stability and the Need for Change", in: Tiersky, R. (ed) Europe Today: National Politics, European Integration and European Security, Rowman and Littlefield Publishers, Maryland, pp.211-250 


\section{Web sources:}

BBC News - $\underline{w w w . b b c . c o m / n e w s}$

BreakingNews.ie - $\underline{w w w . b r e a k i n g n e w s . i e}$

Bruegel - www.bruegel.org

Bloomberg - www.bloomberg.com

CBC News - $\underline{w w w . c b c . c o m / n e w s ~}$

CBS News - $\underline{w w w . c b s n e w s . c o m}$

Centre for Economics and Business Research - www.cebr.com

Centre for European Policy Studies - www.ceps.eu

Centre for European Reform - www.cer.org.uk

Centre for European Studies - UNC - http://europe.unc.edu

Centre for Transatlantic Relations - $\underline{\text { http: //transatlantic.sais-jhu.edu }}$

Council of the European Union - www.consilium.europa.eu

Daily Express - www.express.co.uk

Daily Sabah - www.dailysabah.com

The Economist - www.economist.com

EUbusiness - $\underline{\text { www.eubusiness.com }}$

Euinside.eu - www.euinside.eu

EUobserver - $\underline{\text { www.euobserver.com }}$

EurActiv - www.euractiv.com

Euronews - $\underline{\text { www.euronews.com }}$ 
European Central Bank - www.ecb.europa.eu

European Commission - www.ec.europa.eu/index_en.htm

European Council - www.european-council.europa.eu

European Council on Foreign Relations - $\underline{\text { www.ecfr.eu }}$

European Parliament - www.europarl.europa.eu

European Trade Union Council - www.etuc.org

European Trade Union Institute - www.etui.org

European Voice - $\underline{\text { www.europeanvoice.com }}$

Eurostat - $\underline{\text { http://epp.eurostat.ec.europa.eu }}$

Financial Times - $\underline{\text { www.ft.com }}$

Forex Blog - $\underline{w w w . f o r e x b l o g . o r g}$

France 24 - www.france24.com/en

The Guardian - www.theguardian.co.uk

German Council of Economic Experts - http://www.sachverstaendigenratwirtschaft.de/index.html?\&L=1

German Institute of International and Security Affairs - www.swp-berlin.org

Institut Montaigne - www.institutmontaigne.org

International Institute of European Affairs - www.iiea.com

International Monetary Fund - www.imf.org

Investments \& Pensions Europe - $\underline{\text { www.ipe.com }}$

Investopedia - $\underline{w w w . i n v e s t o p e d i a . c o m ~}$

Irish Central - $\underline{w w w . i r i s h c e n t r a l . c o m}$ 
Johns Hopkins School of Advanced International Studies - www.sais-jhu.edu

TheJournal.ie - $\underline{w w w . t h e j o u r n a l . i e}$

Library of Economics and Liberty - $\underline{w w w . e c o n l i b . o r g}$

The Local - www.thelocal.de

London School of Economics - $\underline{\text { www.lse.ac.uk }}$

National Bureau of Economic Research - www.nber.org

The New York Times - www.nytimes.com

Open Europe - www.openeurope.org.uk

Organisation for Economic Cooperation and Development - www.oecd.org

Portugal Daily View - www.portugaldailyview.com

Reuters - $\underline{w w w . r e u t e r s . c o m}$

Social Europe Journal - www.social-europe.eu

Spiegel Online International - www.spiegel.de/international

The Telegraph - www.telegraph.co.uk

Time Magazine - $\underline{\text { www.time.com }}$

Trading Economics - www.tradingeconomics.com

UK Parliament - www.parliament.uk

Vox - www.voxeu.org

The Wall Street Journal - http:/ / online.wsj.com

Washington Centre for Equitable Growth - http://equitable.org/blog

Xinhuanet News Agency - http://news.xinhuanet.com/english

Youtube - $\underline{w w w . y o u t u b e . c o m}$ 